\title{
Design and Synthesis of Natural Product Inspired Libraries Based on the 3D Cedrane Scaffold: Towards the Exploration of 3D Biological
}

\author{
Space \\ Fatemeh Mazraati Tajabadi, Rebecca H. Pouwer, Miaomiao Liu, Yousef Dashti, \\ Marc R. Campitelli, Mariyam Murtaza, George D. Mellick, Stephen A. Wood, Ian \\ D. Jenkins, Ronald J. Quinn*
}

Griffith Institute for Drug Discovery, Griffith University, Brisbane, QLD 4111, Australia

\begin{abstract}
A chemoinformatic method was developed to extract non-flat scaffolds embedded in natural products within the Dictionary of Natural Products (DNP). The cedrane scaffold was then chosen as an example of a non-flat scaffold that directs substituents in threedimensional (3D) space. A cedrane scaffold that has three orthogonal handles to allow generation of 1D, 2D and 3D libraries was synthesised on a large-scale. These libraries would cover more than $50 \%$ of the natural diversity of natural products with an embedded cedrane scaffold. Synthesis of three focused natural product-like libraries based on the 3D cedrane scaffold was achieved. A phenotypic assay was used to test the biological profile of synthesized compounds against normal and Parkinson's patientderived cells. The cytological profiles of the synthesized analogues based on the cedrane scaffold revealed that this 3D scaffold, pre-validated by nature, can interact with biological systems as it displayed various effects against normal and Parkinson's patient-derived cell lines.
\end{abstract}




\section{INTRODUCTION}

Natural products are an important source of inspiration for the development of therapeutically useful compounds. ${ }^{1}$ Many marketed drugs have natural origins with $32 \%$ of developed therapeutic drugs approved by the US Food and Drug Administration (FDA), between 1981 and 2014 being natural products or natural product-derived. ${ }^{2}$ In the ongoing search for novel drug candidates, the extraordinary chemical complexity of those natural products that contain high numbers of $s p^{3}$ hybridized carbons and chiral centres $^{3-7}$ may be exploited to access neglected chemical space and avoid flatland. ${ }^{8,9}$

From a biomolecular interaction perspective, natural products have met at least one biosynthetic enzyme, providing an embedded biological imprint. ${ }^{10-14}$ High chemical diversity and embedded biosynthetic molecular recognition may explain the high success rate of natural products in hitting biological targets. The so far explored chemical universe, however, is suffering from insufficient overlap/correlation between biological and chemical space. With some essential biological targets such as phosphatases and protein-protein interactions, it has proved difficult to find small molecule modulators of function. ${ }^{15}$ Several synthetic approaches have been introduced inspired by nature to insert more complexity and diversity into the chemical collections. These include diversity-oriented synthesis, ${ }^{16,17}$ target-oriented synthesis, ${ }^{16,}{ }^{18}$ functionoriented synthesis, ${ }^{19}$ and biology-oriented synthesis. ${ }^{20,21}$

Current commercial compounds tend to be flat, mainly composed of planar aromatic and heteroaromatic scaffolds $\left(\mathrm{F} s p^{3}<0.45\right){ }^{22}$ The vast majority of scaffolds utilized in synthetic approaches are flat $(22 \%$ non-flat) while the trend is reversed in natural products with more than $75 \%$ non-flat scaffolds. ${ }^{22}$ According to Hert et al. ${ }^{23} 83 \%$ of the ring scaffolds among natural products are absent from commercial molecules. While the cost effectiveness and simple synthesis of aromatic systems may justify the popularity 
of planar chemical collections, investing in the development of non-flat scaffolds that are pre-validated in nature may provide a generation of diverse natural product-based libraries that have the potential to cover neglected areas of biological space.

Herein, we describe an approach to identify non-flat scaffolds from the DNP that have high potential in directing pendant groups in 3D space. A chemoinformatic process was developed to overlay and cluster natural products based on their common core in order to visualize and assess the ability of a scaffold to direct the orientation of substituents in 3D space. Amongst the identified 3D natural product scaffolds, cedrane (1) was chosen for further studies. The cedrane scaffold is highly saturated $\left(F s p^{3}=1\right)$ with 3 chiral centres and directs the orientation of pendent groups in three dimensional space. Furthermore, a range of biological activities have been reported for natural products and synthetic compounds containing the cedrane scaffold. ${ }^{24-31}$ A series of compounds based on the cedrane scaffold were synthesized to assess their biological activity using a phenotypic assay against a Parkinson's patient-derived cell line. ${ }^{32}$ In this cell-based multidimensional profiling method, the effects of compounds on six independent cellular compartments on a patient-derived cell model were investigated. The assay utilised non-transformed/non-immortalized primary human olfactory neurospherederived (hONS) cells with a normal karyotype, derived from a patient with idiopathic Parkinson's disease (PD). ${ }^{33,} 34$ This aims to study a disease state and enables investigation of multiple targets and pathways. For disorders such as Parkinson's and Alzheimer's diseases, for which target-based strategies have failed to produce successful drug candidates for clinical development, this strategy may identify novel drug targets. ${ }^{35}$ 


\section{RESULTS AND DISCUSSION}

\section{Identification of 3D Scaffolds Embedded in Natural Products}

A multistep analysis was performed on the secondary metabolites represented in the DNP to identify 3D scaffolds embedded in natural products (Figure 1). Initially all ring systems in the DNP were abstracted according to the Bemis and Murcko method. ${ }^{36}$ Then, in order to preserve important chemical functionality (e.g. the carbonyl oxygen present in a lactone ring), all contiguous ring systems were extracted with retention of exocyclic double bonds to terminal atoms. Metal-containing ring systems were excluded from consideration, resulting in the identification of 18,128 ring systems. To exclude large, non-drug-like ring systems (e.g. polycyclic ring systems and macrocycles) an additional molecular weight filter $(\mathrm{MW}<350 \mathrm{Da})$ was applied which resulted in 15,822 natural product derived scaffolds. In order to increase the drug-likeness of the extracted scaffold library, the following property filters were applied: number of aromatic rings $<$ 3 ; number of rings $<4$; number of bonds $<20$; $\mathrm{S} \leq 2$; $\mathrm{O} \leq 4$; $\mathrm{N} \leq 4$. This resulted in 6,102 natural product derived scaffolds. This scaffold subset was investigated to identify non-flat scaffolds $\left(\mathrm{Fsp}^{3}>0.45\right)^{22}$ located within the central core of a natural product, with the ability to direct substituents in $3 \mathrm{D}$ space. 


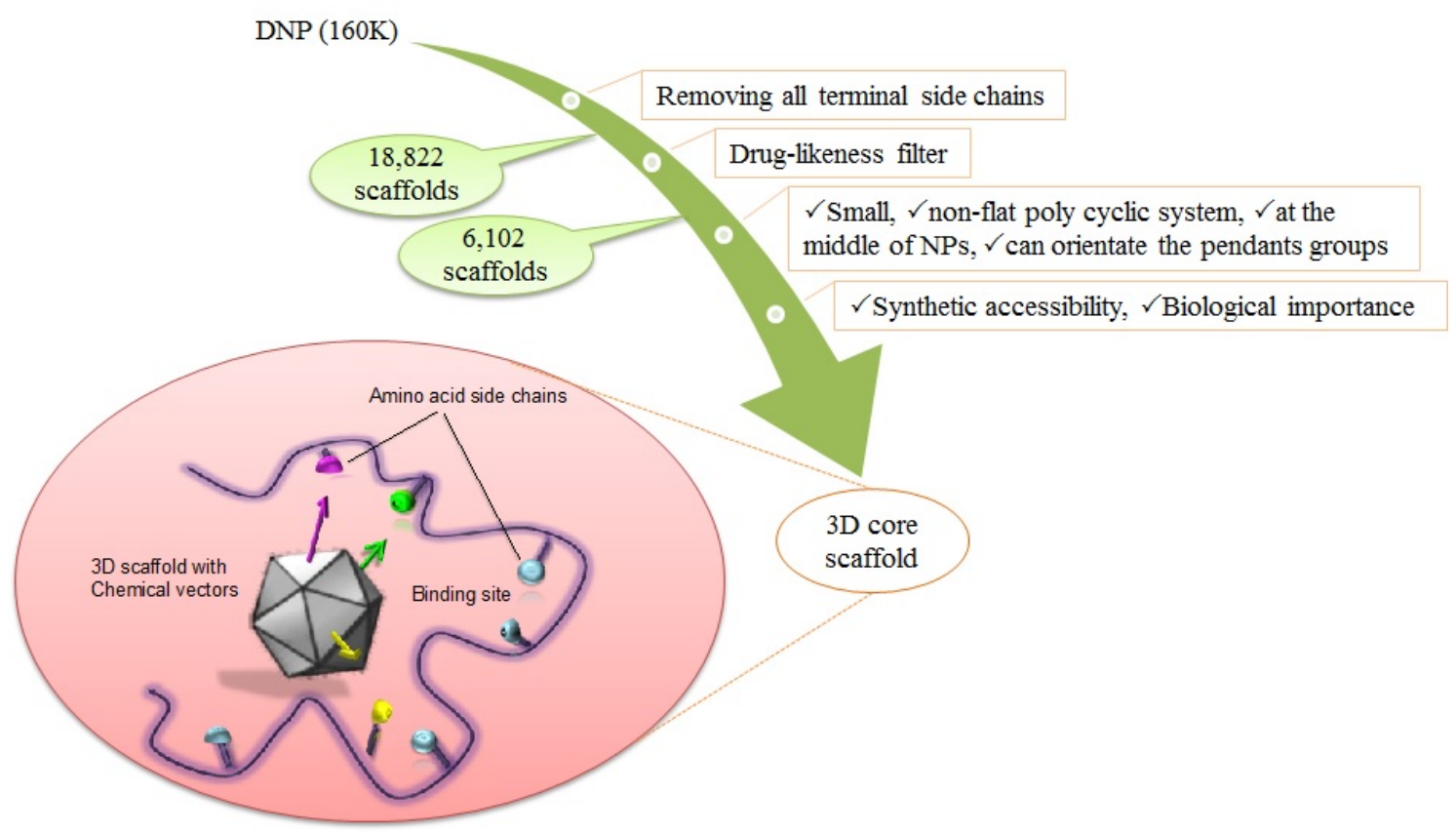

Figure 1. Summarized process used for identification of non-flat (3D) natural product scaffolds from DNP.

Natural product ring systems meeting these criteria were then ranked based on synthetic viability and biological activity of the parent natural products. For this proof of concept study, the cedrane scaffold 1 (Figure 2) was selected as a suitable candidate for further study. There are 161 natural products reported in the DNP that contain the scaffold $\mathbf{1}$, providing a reasonable sample size for molecular modelling. In addition, scaffold 1 is highly saturated $\left(\mathrm{F} s p^{3}=1\right)$, bearing 3 chiral centres and natural products containing scaffold $\mathbf{1}$ have a range of biological activities (Figure 2). For instance, elisapterosin B (2) has shown strong in vitro anti-tuberculosis activity, ${ }^{24}$ takaneone B (3) has been reported as a cytotoxic compound against K562/Adr multidrug-resistant (MDR) cancer cells, ${ }^{25}$ taxuspine $\mathrm{H}$ (4) showed microtubule depolymerisation ${ }^{26}$ and cytotoxicity towards $\mathrm{V}-13$ cells,${ }^{27}$ phloroglucinol derivative 5 revealed activity against Bacillus cereus, 
Staphylococcus epidermidis and Micrococcus luteus, ${ }^{28}$ and merochlorin A (6) showed in vitro activity against Methicillin-resistant Staphylococcus aureus. ${ }^{37}$

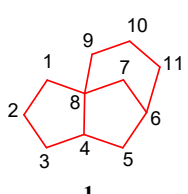

Cedrane scaffold

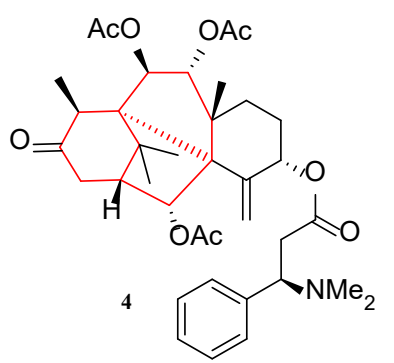

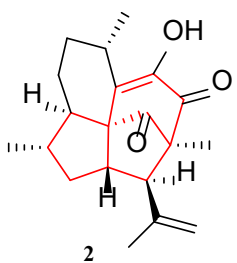

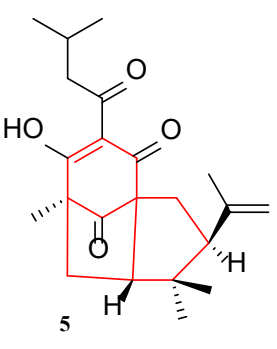

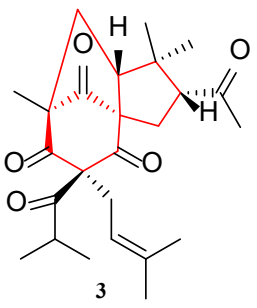

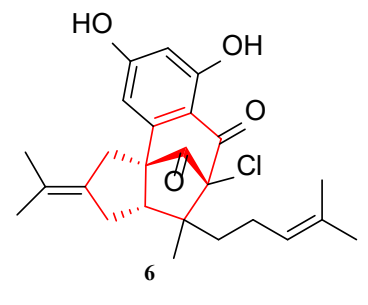

Figure 2. Cedrane scaffold 1 and structure of some bioactive compounds that contain scaffold $\mathbf{1}$.

\section{Assessment of Scaffold-directed Occupation of 3D Space}

All 161 natural products reported in the DNP that contain scaffold 1 were overlaid and clustered based on their common core using molecular modelling in order to visualize and assess the ability of the scaffold to direct the substituents in 3D space. Of the 161 natural products that contain scaffold 1, eight compounds have defined absolute configuration. To perform clustering, firstly all 161 natural product structures containing the cedrane skeleton were drawn in Maestro-Schrödinger software (version 9.7). For the natural products with relative configuration (153 molecules), a mirror structure of each molecule was also drawn. Multi-minimization was performed on all structures using MacroModel. The two most complete and well-parameterized force fields, MMFFs (Merck Molecular Force Field) and OPLS (Optimized Potentials for Liquid Simulations)-2005, were used in energy calculations. At the primary stages of calculations, it was found that MMFFs, in a few cases, provided two different global minima for basically identical structures. The quality comparison of three parameters 
(stretch, bend and torsion parameters) revealed that OPLS 2005 with a larger "high quality" torsion parameter (241 vs 221) and less "low quality" torsion parameter (0 vs 21) is more appropriate for the energy calculations in this study (Table S1). Therefore, OPLS 2005 force field was employed for minimization followed by conformational search using the same force field to retain only the lowest energy conformer of each structure.

A similar order of atom numbers was applied for the cedrane scaffold in each natural product; therefore, renumbering based on "scaffold heavy atoms" was a necessary step prior to clustering. As there was no defined function in Maestro to change numbering order, Chem \& Bio 3D was used to sort the atom number order of the scaffold in all natural products. For the natural products with relative configuration the true enantiomer structure was established through X-cluster using atomic RMSD as a distance criterion. It provides similarity comparison between pairs of structures following rigid-body superposition. The similarity matrix provided by X-clustering allows a many by many superimposition of scaffold heavy atom of each relative structure on one or more absolute structures. The corresponding r.m.s. (root mean square) values were determined and compared. Using this matrix, the relative structures with higher r.m.s. values resulted from overlaying on the absolute structures were omitted from consideration. Finally, all 161 structures were superimposed based on the cedrane scaffold using the average linkage method, which resulted in 9 clusters (Figure 3). The same criterion of atomic RMS (clustering level: 0.21) was used in X-clustering which clustered the NPs containing the cedrane core based on the geometry of the cedrane core and their distance between atoms within the core. This groups structures that have substituents on the core scaffold protruding in the same relative orientation in space. 


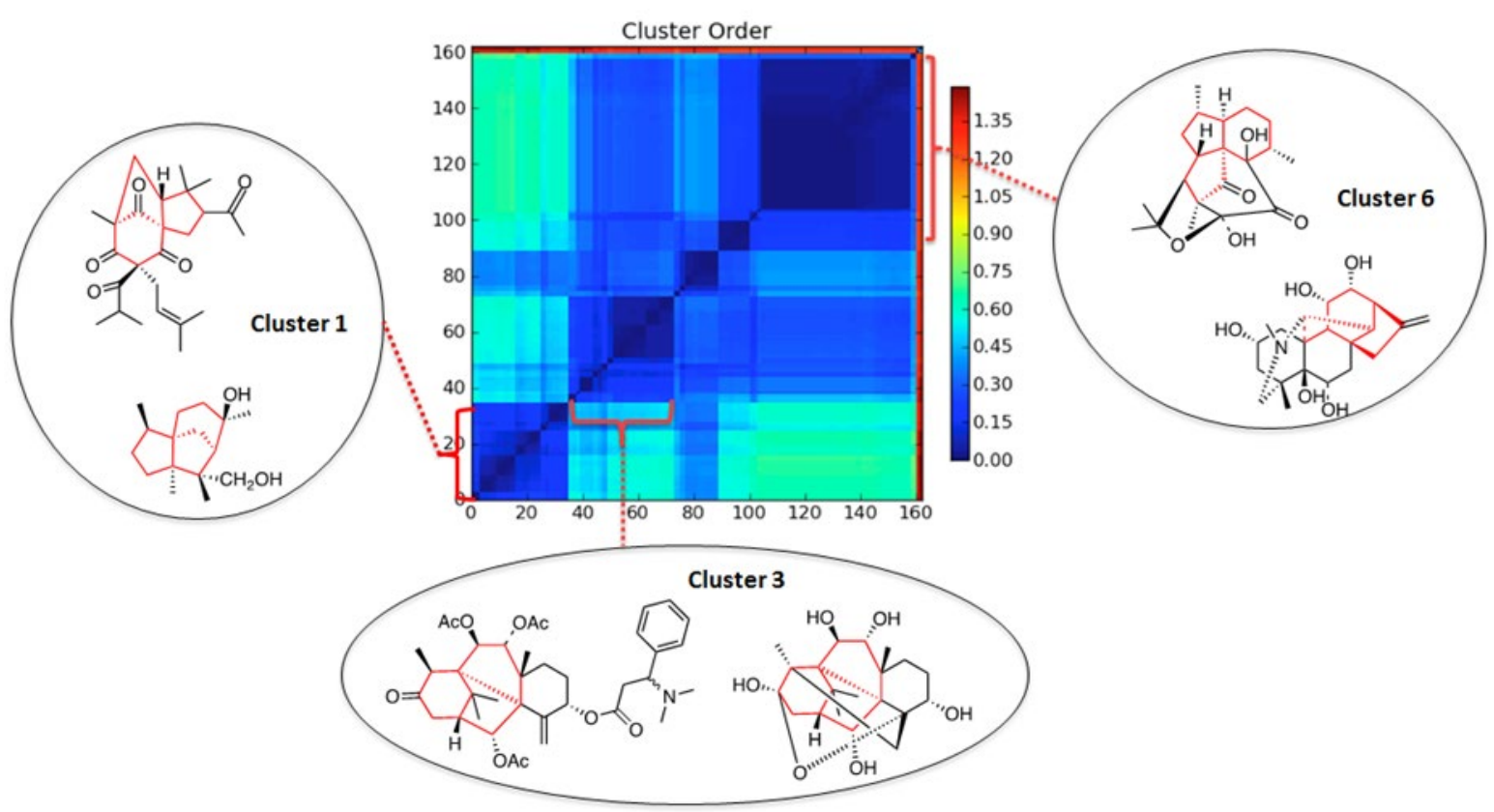

Figure 3. Clustering 161 natural products containing the cedrane scaffold based on the geometry of the cedrane core and their distance between atoms within the core gave 9 clusters. Three major clusters, cluster 6 with 69 natural product hits, clusters 1 and 3 each with 35 NPs are delineated with two examples of NP molecules present in their group. Clusters 1, 3 and 6 plus cluster 5 composed of 14 hits were the 4 major clusters that cover $>95 \%$ (153 out of 161) of natural products bearing the cedrane scaffold. Minor clusters were clusters $2,4,7,8$ and 9 with $3,2,2,1$ and 1 hit (s), respectively, representing only 8 molecules from 161 NPs in the DNP.

The numbers of natural products represented in clusters 1 to 9 were $35,3,35,2,14,69$, 2, 1 and 1, respectively. Cluster 6 with 69 natural product hits, clusters 1 and 3 each with 35 natural products and cluster 5 composed of 14 hits were the 4 major clusters that cover $>95 \%$ (153 out of 161 ) of natural products containing scaffold $\mathbf{1}$. The other 5 clusters only represent 8 natural products.

The results of overlaying clustered natural products for the 3 major clusters are depicted in Figure 4. Natural products in cluster 6 (69 hits), tend to be functionalized in positions $1,3,5,9$, and 11 . Figure 5 demonstrates that the cedrane core orientates the substituents from 69 overlaid natural product molecules into relatively limited areas of space as shown by the highlighted arrows. Cluster 1 (35 hits) natural products are functionalized 
in positions 1, 2, 3, 4 and 5 with a tendency towards large substituents. Natural products in cluster 3 (35 hits) bear substituents in positions 1, 2, 3, 4, 5, 6 and 10 of the cedrane scaffold with positions 3 and 4 mainly linked through a functionalized 6 membered fused ring. Thus, all ten positions of scaffold $\mathbf{1}$ are substituted in Nature.

\section{Synthesis of the Cedrane Scaffold and Selection of Diversifying Reagents}

According to the molecular modelling results, synthesizing all possible disubstituted libraries based on the cedrane scaffold is desirable to explore $3 \mathrm{D}$ biological space around the scaffold. A comprehensive literature survey revealed that 23 out of 45 possible disubstituted combinations for 2D libraries (Figure S1) are achievable using methods reported in the literature. To generate one- and multi-dimensional libraries containing a cedrane core, a scaffold with three orthogonally reactive chemical handles was synthesised on a $5 \mathrm{~g}$ scale (Scheme 1). ${ }^{38-40}$ Briefly, the methylation of 7 with iodomethane was promoted by 


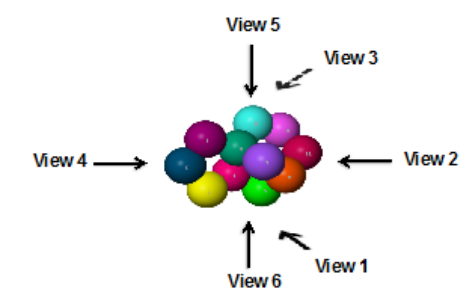

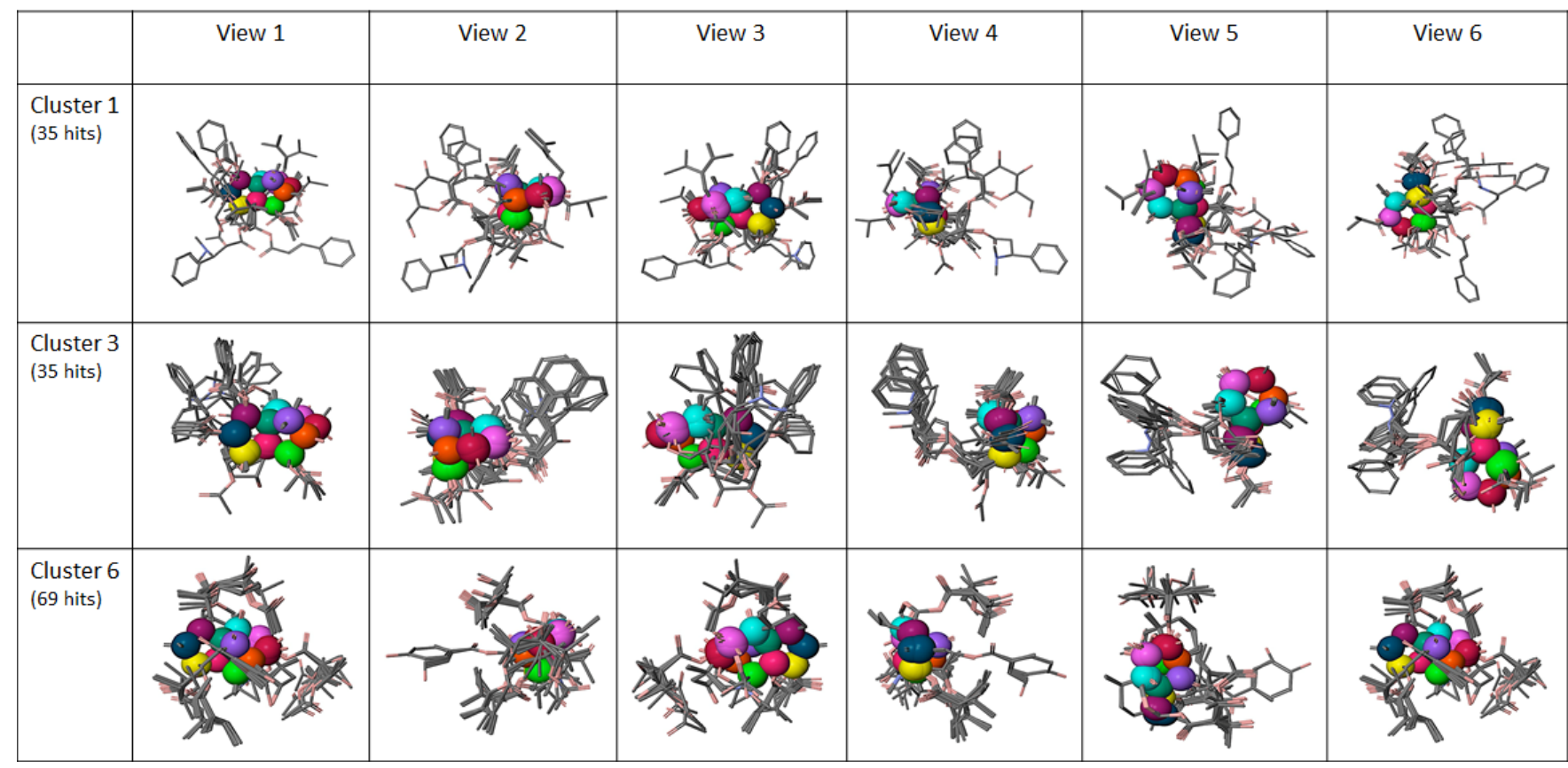

Figure 4. Six different views of natural products containing the cedrane scaffold in the 3 major clusters. Characterization of each cluster: Clusters 1 (35 hits in DNP) functionalized in positions 1, 2, 3, 4 and 5. Cluster 3 (35 hits) functionalized in positions 1, 2, 3, 4, 5, 6 and 10 where mostly positions 3 and 4 are attached to each other through a functionalized 6 member fused ring. Cluster 6, the largest cluster, which covers 69 hits, is heavily decorated in positions 1,3,5, 9, and 11. 


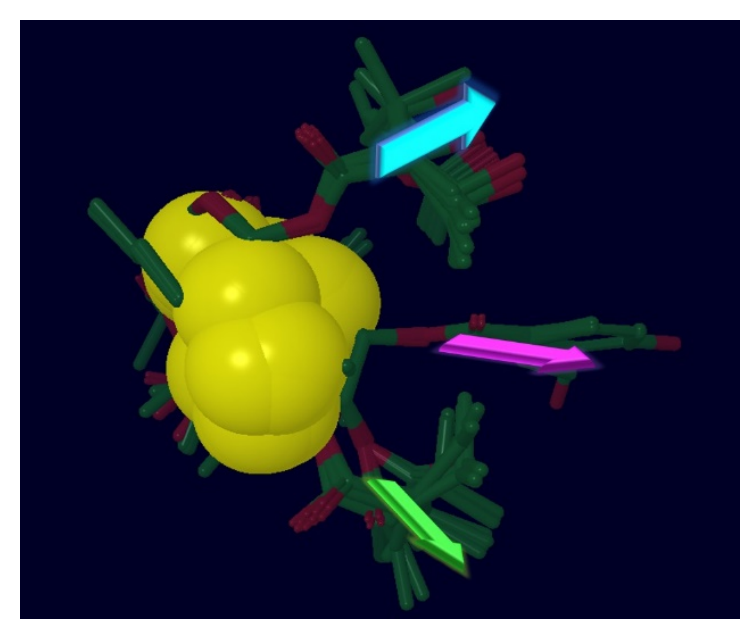

Figure 5. Sixty-nine natural product molecules in cluster 6 overlaid based on the cedrane scaffold $\mathbf{1}$. Highlighted arrows show the $3 \mathrm{D}$ orientation of the precursors into a relatively limited space by cedrane scaffold.

Scheme 1. Synthetic plan adopted from literature to make cedrane scaffold with three orthogonally reactive chemical handles. ${ }^{\mathrm{a}}$

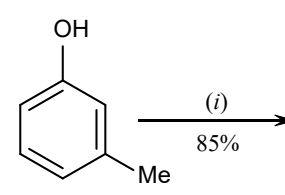

7<smiles>CC#CCCC1=CCC=C(OC)C1</smiles>
9<smiles>COC1=CC(C)CC(C)C1CC1CC2CC1C(C)C2(C)N</smiles>

10 $11^{\alpha}{ }_{\beta}$ (iv) $\ 2 \%$

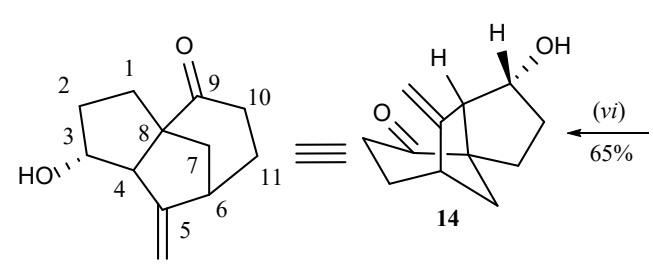<smiles>CO[C@]1(CCC2OCCCO2)C=C(C)C2CC1C2</smiles><smiles>CC1=C(C)C2CC1CC(C)C2(C)C</smiles>

a(i) MeI, K2CO3, acetone, reflux, (ii) $\mathrm{Na}, \mathrm{NH}_{3}$ (liq), $\mathrm{H}_{2} \mathrm{O}, \mathrm{EtOH}$, (iii) acrylonitrile, $120{ }^{\circ} \mathrm{C}, 16 \mathrm{~h}$ (iv) a: LDA/THF, $-78{ }^{\circ} \mathrm{C}$; b: $\mathrm{O}_{2}-78{ }^{\circ} \mathrm{C}$; c: $\mathrm{Na}_{2} \mathrm{SO}_{3}, 0-25{ }^{\circ} \mathrm{C}$, (v) 2-(2-bromoethyl)-1,3-dioxane, $\mathrm{Mg}, \mathrm{Br}\left(\mathrm{CH}_{2}\right)_{2} \mathrm{Br},(v i)$ TsOH, acetone, reflux. 
potassium carbonate in refluxing acetone to give $\mathbf{8}$ in $85 \%$ yield. ${ }^{38}$ Then, Birch reduction of $\mathbf{8}$ yielded $9(70 \%)$. Cycloaddition of acrylonitrile and the conjugated diene 10, generated in situ from $\mathbf{9}$, gave a mixture of nitriles $\mathbf{1 1 a}, \mathbf{b} \cdot{ }^{39}$ Deprotonation of $\mathbf{1 1}$ with lithium diisopropylamide followed by treatment with oxygen, and subsequent reduction with sodium sulfite gave the ketone $\mathbf{1 2}$ in 72\% yield. Ketone $\mathbf{1 2}$ was then treated with 2-(2-bromoethyl)-1,3-dioxane and magnesium turnings in THF to obtain a readily separable mixture of endo (13a) and exo alcohols (13b) in 62:38 ratio in good yield (75\%). In the final step, the mixture of alcohols $\mathbf{1 3}$ underwent pinacol rearrangement to yield ketone 14, upon treatment with $p$ - $\mathrm{TsOH}$ (1.3 eq) in refluxing acetone for $16 \mathrm{~h} .{ }^{40}$ This strategy provided $5 \mathrm{~g}$ of scaffold with three orthogonally reactive chemical handles allowing decoration at positions 3,5 and 9 to generate 1D, 2D and 3D libraries that sample the diversity of the natural products. The overall approach for library generation is outlined in Scheme 2. Esterification of the $\alpha$-hydroxyl group at C3 of $\mathbf{1 4}$ afforded Chemset 1 (15a-15r). In order to prepare the second library, the C3 hydroxyl group of 14 was inverted through a Mitsunobu reaction to give intermediate 16 (Scheme 6) which was followed by hydrolysis to yield 17. Subsequent esterification of the resulting alcohol with the same groups utilized in the first library synthesis generated Chemset 2 . Finally, the members of Chemset 1 were subject to sodium borohydride reduction to yield Chemset 3 .

To select the diversifying reagents and avoid a totally random diversification in the generated libraries, an R-group analysis was performed on the 161 cedrane scaffold containing natural products reported in the DNP to determine the patterns of functionalization by Nature in the 10 available positions (Figure S2). This selected diversification will also give us a chance to further examine the hypothesis regarding the similarities of the active sites of proteins involved in biosynthetic pathways and biological targets ${ }^{10,} 11$ through the analysis of 
biological responses. The R-group analysis identified mostly esterification at position 3 . Carboxylic acids A-R used for the esterification of the cedrane scaffold to generate the 3 libraries (Chemset 1, 2 and 3) are presented in Figure 6. Carboxylic acids A-E correspond directly to known natural product $\mathrm{C} 3$ substituents. The remaining acid reagents $\mathbf{F}-\mathbf{R}$ were selected for structural diversity

Scheme 2. Overall approach to generate 1D focused libraries of Chemset 1 and Chemset 2 along with 2D library of Chemset 3 based on the cedrane scaffold.

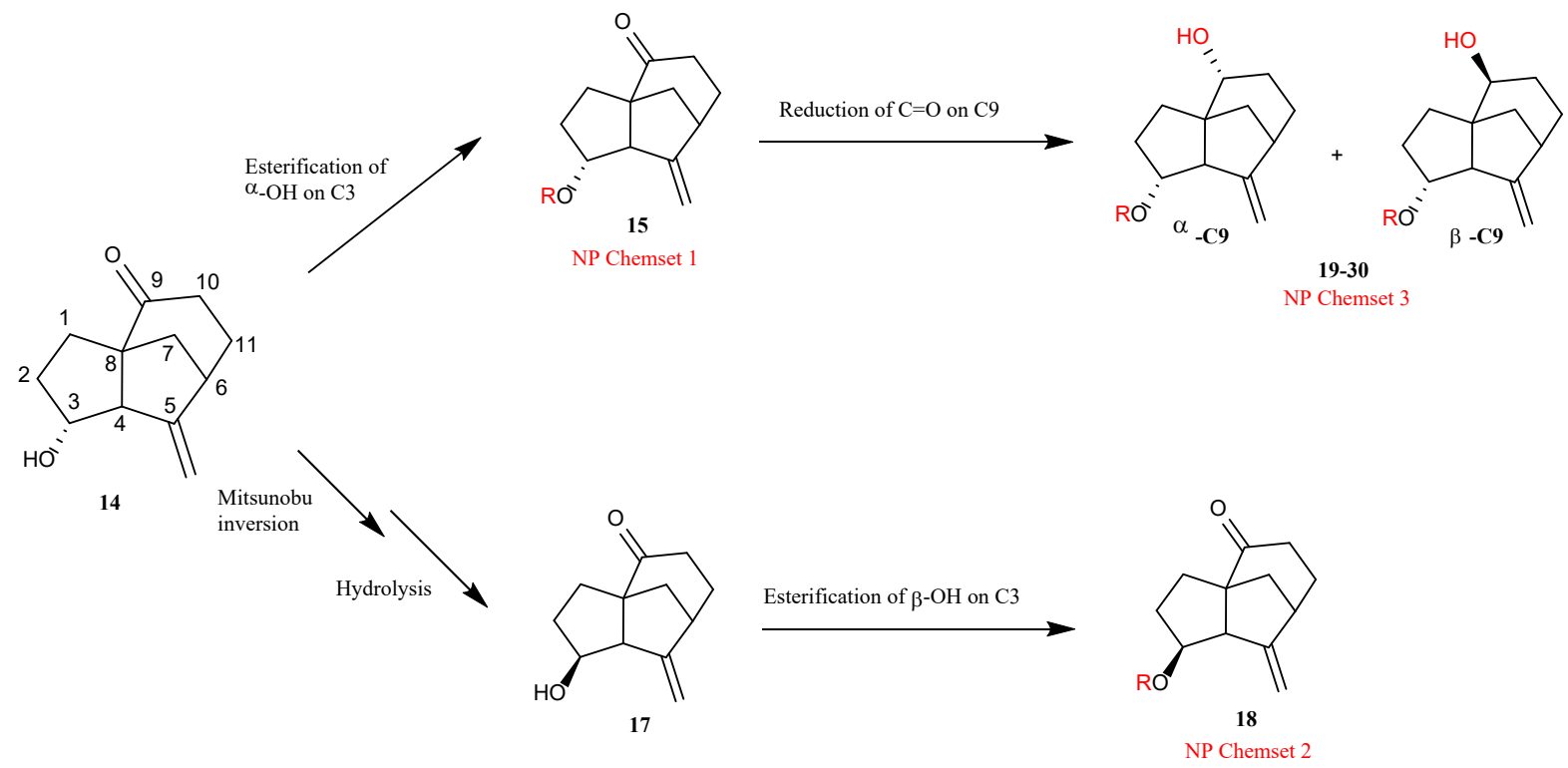

and drug-likeness. ${ }^{41}$ Specifically, carboxylic acids that contained inappropriately reactive functional groups and elements (e.g. boronic acids, nitro, sulfate, sulfur, halogens...) were not considered. In order to assess the drug-like properties of the 60 synthesized compounds their physicochemical properties were analyzed and checked against Lipinski's Rule of 5 (Figure 7 and Table S3). All synthesized molecules had between 0-2 HBD and 2-3 HBA, and as depicted in Figure 7, molecular weight and calculated $\log P$ of the synthesized compounds are in the acceptable drug-like range. 

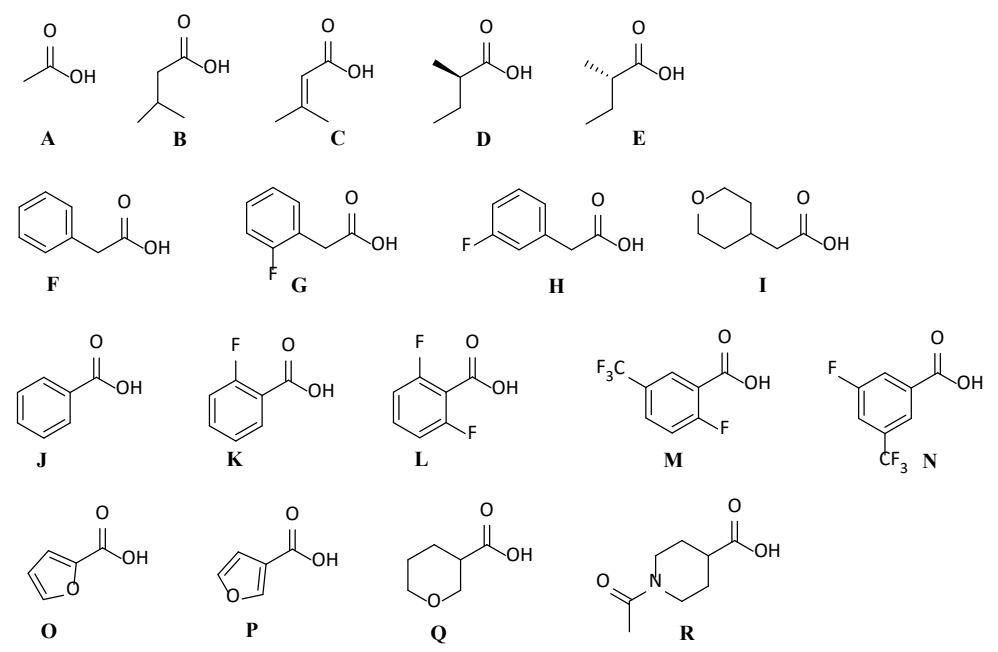

Figure 6. Diversifying reagents A-R used for library generation.
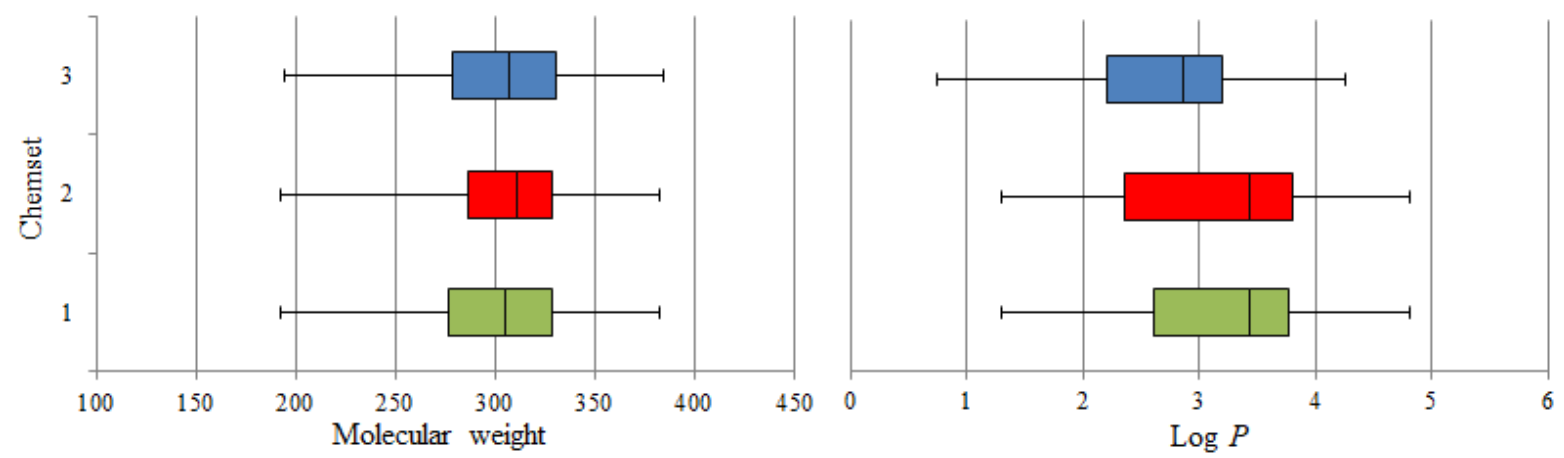

Figure 7. Boxplot of the molecular weight and $\log P$ of the Chemsets 1 (green), 2 (red), and 3 (blue).

\section{Synthesis of 1D and 2D Libraries at Positions 3 and 9 of the Cedrane Scaffold}

Synthesis of Chemset 1 was achieved via esterification of the $\alpha$-alcohol at C3 with carboxylic acids A-R to afford esters 15 (Scheme 3). Esterification was generally carried out via the corresponding acid chlorides, followed by coupling with the hydroxyl group of the cedrane scaffold in the presence of triethylamine (procedure $(i)$ ). The reactions proceeded in moderate to good yields (Table 1) with the exception of esters $\mathbf{1 5 0}$ and $\mathbf{1 5 p}$, which were obtained in only $10 \%$ yield. Ester 15a was obtained in $87 \%$ yield through acetylation of the hydroxyl group using acetic acid anhydride in the presence of 4-dimethylaminopyridine 
(DMAP) (procedure (ii)). Esterification of the hydroxyl group of the cedrane scaffold with acid reagent $\mathbf{R}$ was carried out similarly by conversion to the corresponding acid chloride with thionyl chloride followed by coupling with 14 in the presence of DMAP and pyridine as solvent (procedure (iii)) to afford the ester $15 \mathrm{r}$ in $75 \%$ yield.

Scheme 3. Synthetic procedures used to generate Chemset $1^{\text {a }}$
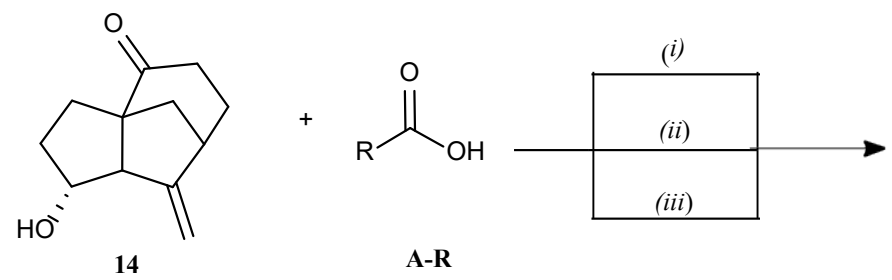

A-R

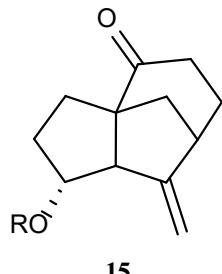

a( $i)$ a: $(\mathrm{COCl})_{2}, \mathrm{DCM}, \mathrm{DMF}$ (1-2 drops), rt, 2 h; b: Acid chloride, Et ${ }_{3} \mathrm{~N}, \mathrm{DCM}$, DMAP (cat. amount), rt, 4-24 h, (ii) $\left(\mathrm{CH}_{3} \mathrm{CO}\right)_{2} \mathrm{O}, \mathrm{DMAP}, \mathrm{Et}_{3} \mathrm{~N}$, rt, $20 \mathrm{~h}$, (iii) $\mathrm{SOCl}_{2}$, DMAP, pyridine, $17 \mathrm{~h}$.

NMR analysis of the product of the esterification of the $\alpha-\mathrm{OH}$ on $\mathrm{C} 3$ with 3,3dimethylacrylic acid (acid reagent $\mathbf{C}$ in Figure 6) revealed that the expected ester product 15c was not produced. Instead, the $\beta, \gamma$-unsaturated ester $\mathbf{1 5} \mathbf{c}^{\prime}$, resulting from deconjugative rearrangement of the side-chain, was produced (Scheme 4). A mechanism for the formation of compound $\mathbf{1 5} \mathbf{c}^{\prime}$ via a ketene intermediate is suggested in Scheme $5 .{ }^{42}$

Scheme 4. Production of unexpected rearranged product 15c' and synthesis of diastereomers $21 \boldsymbol{\alpha}$ and $21 \boldsymbol{\beta}$ from compound $15 \mathrm{c}^{\prime}$. $^{\mathrm{a}}$

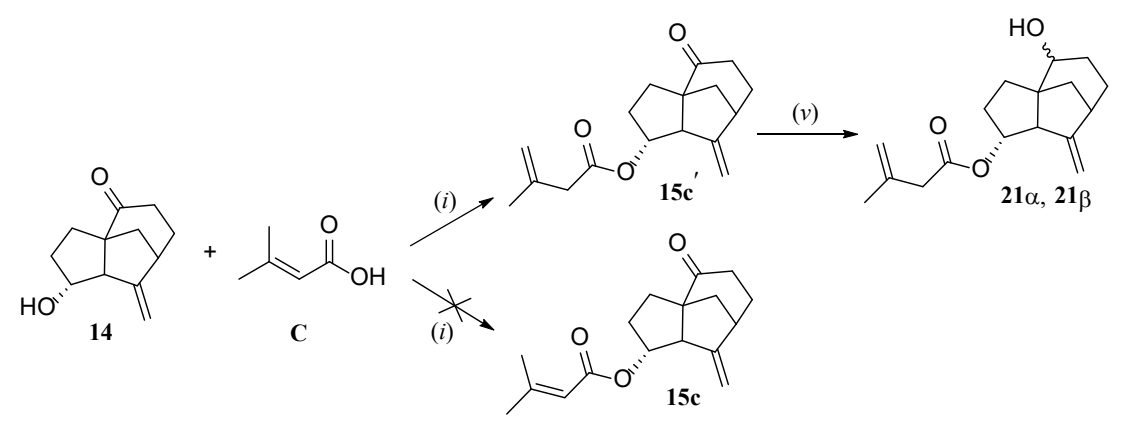

a( $i)$ See scheme 3, (v) a) $\mathrm{NaBH}_{4}, \mathrm{MeOH}, 0^{\circ} \mathrm{C}, 1 \mathrm{~h}$; b) $\mathrm{HCl}(2 \mathrm{M}), 10 \mathrm{~min}$. 
Scheme 5. Mechanism of formation of 15c'.

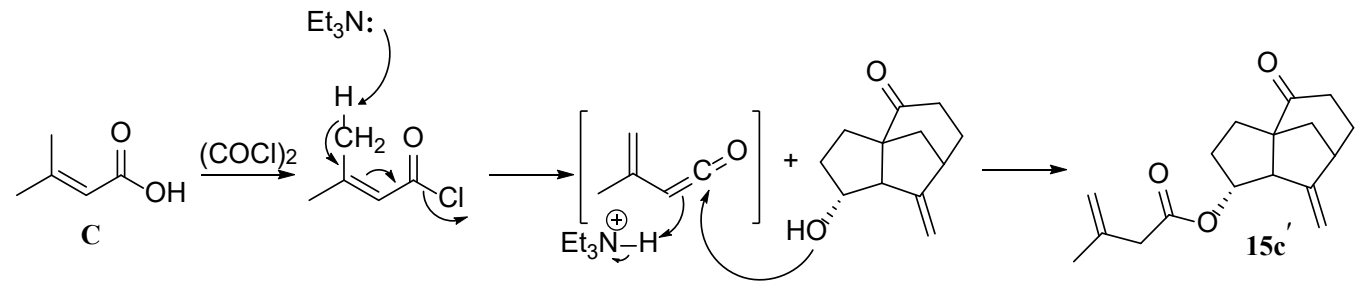

Table 1. Isolated yields for compounds $\mathbf{1 5}$ in Chemset $1^{a}$

\begin{tabular}{cccccccc}
\hline Compound & $\mathrm{R}$ & Procedure & Yield & Compound & $\mathrm{R}$ & Procedure & Yield \\
\hline $15 \mathrm{a}$ & $\mathrm{A}$ & $(i i)$ & $87 \%$ & $15 \mathrm{j}$ & $\mathrm{J}$ & $(i)$ & $56 \%$ \\
$15 \mathrm{~b}$ & $\mathrm{~B}$ & $(i)$ & $70 \%$ & $15 \mathrm{k}$ & $\mathrm{K}$ & $(i)$ & $56 \%$ \\
$15 \mathrm{c}^{\mathrm{b}}$ & $\mathrm{C}$ & $(i)$ & $56 \%$ & $15 \mathrm{l}$ & $\mathrm{L}$ & $(i)$ & $30 \%$ \\
$15 \mathrm{~d}$ & $\mathrm{D}$ & $(i)$ & $63 \%$ & $15 \mathrm{~m}$ & $\mathrm{M}$ & $(i)$ & $45 \%$ \\
$15 \mathrm{e}$ & $\mathrm{E}$ & $(i)$ & $61 \%$ & $15 \mathrm{n}$ & $\mathrm{N}$ & $(i)$ & $42 \%$ \\
$15 \mathrm{f}$ & $\mathrm{F}$ & $(i)$ & $58 \%$ & $15 \mathrm{o}$ & $\mathrm{O}$ & $(i)$ & $10 \%$ \\
$15 \mathrm{~g}$ & $\mathrm{G}$ & $(i)$ & $61 \%$ & $15 \mathrm{p}$ & $\mathrm{P}$ & $(i)$ & $10 \%$ \\
$15 \mathrm{~h}$ & $\mathrm{H}$ & $(i)$ & $57 \%$ & $15 \mathrm{q}$ & $\mathrm{Q}$ & $($ i) & $42 \%$ \\
$15 \mathrm{i}$ & $\mathrm{I}$ & $(i)$ & $42 \%$ & $15 \mathrm{r}$ & $\mathrm{R}$ & $($ iii $)$ & $75 \%$ \\
\hline
\end{tabular}

${ }^{a}$ See Scheme 3 for conditions (i)-(iii). ${ }^{b}$ See Scheme 4 for the structure of 15c'.

Chemset 2 was generated using the inverted alcohol 17 with the aim of introducing the same substituents as Chemset 1 in order to study the effect of stereochemistry and 3D orientation on biological activity. The Mitsunobu reaction was employed to generate the inverted cedrane scaffold 17 from 14 according to Scheme 6. Alcohol 14 was treated with $p$ nitrobenzoic acid in the presence of diisopropyl azodicarboxylate (DIAD), triphenylphosphine $\left(\mathrm{PPh}_{3}\right)$ and toluene as solvent at $80{ }^{\circ} \mathrm{C}$ for $2 \mathrm{~h}$. The generated ester 16 was then hydrolyzed using potassium hydroxide to give inverted alcohol 17. Esterification of 17 with carboxylic acids A, B, D, F-R (Figure 6) afforded esters 18a, 18b, 18d, 18f-18r in moderate to good yields with the exception of compounds $\mathbf{1 8 0}$ and $\mathbf{1 8 p}$ with $12 \%$ yields (Table 2). 
Scheme 6. Synthesis of Chemset $2^{\text {a }}$

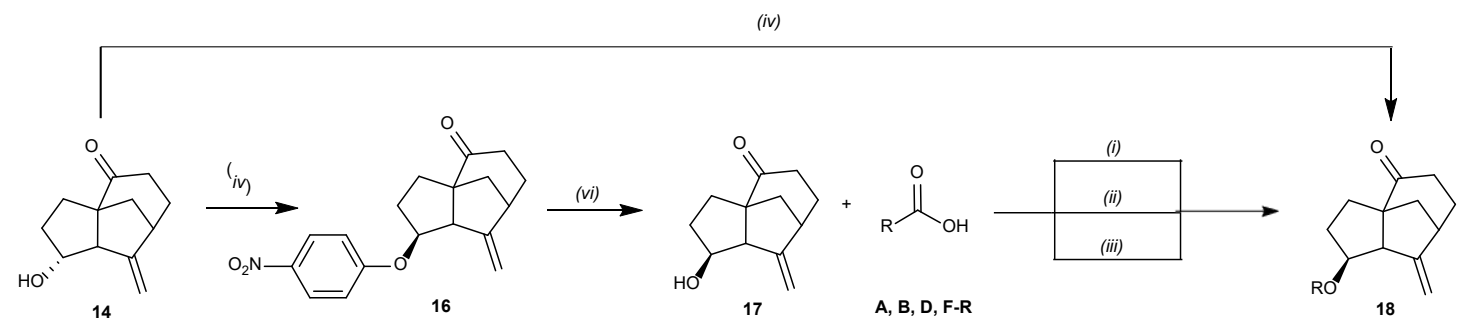

a (i ) a: $(\mathrm{COCl})_{2}$, DCM, DMF (1-2 drops), rt, 2 h; b: Acid chloride, Et ${ }_{3} \mathrm{~N}, \mathrm{DCM}, \mathrm{DMAP}$ (cat. amount), rt, 4-24 h; (ii) $\mathrm{Ac}_{2} \mathrm{O}, \mathrm{DMAP}, \mathrm{Et}_{3} \mathrm{~N}, \mathrm{rt}, 20 \mathrm{~h}$; (iii) a: $\mathrm{SOCl}_{2}$, DMAP, dry pyridine, $17 \mathrm{~h}$; (iv) $\mathrm{PPh}_{3}$ (2.5 eq), DIAD (2.5 eq), toluene, $80{ }^{\circ} \mathrm{C}, 2 \mathrm{~h} ;(v i) \mathrm{KOH}, \mathrm{EtOH}, 50{ }^{\circ} \mathrm{C}, 3 \mathrm{~h}$.

In general procedure (i) was used to produce the corresponding acid chloride from the carboxylic acid, followed by coupling of the acid chloride and $\beta$-hydroxyl group in the presence of triethylamine. However, phenylacetic acid derivatives (18f-18h) and ester 18i were not produced by procedure (i). Instead, a Mitsunobu reaction, which was used to produce compound 16, was used to produce derivatives $\mathbf{1 8 f}-\mathbf{1 8 i}$ directly from $\mathbf{1 4}$ in good yield (procedure $i v$ in Scheme 6).

Table 2. Isolated yields for compounds $\mathbf{1 8}$ in Chemset $2^{a}$

\begin{tabular}{cccccccc}
\hline Compound & $\mathrm{R}$ & Procedure & Yield & Compound & $\mathrm{R}$ & Procedure & Yield \\
\hline $18 \mathrm{a}$ & $\mathrm{A}$ & $(i i)$ & $85 \%$ & $18 \mathrm{k}$ & $\mathrm{K}$ & $(i)$ & $76 \%$ \\
$18 \mathrm{~b}$ & $\mathrm{~B}$ & $(i)$ & $56 \%$ & 181 & $\mathrm{~L}$ & $(i)$ & $39 \%$ \\
$18 \mathrm{~d}$ & $\mathrm{D}$ & $(i)$ & $68 \%$ & $18 \mathrm{~m}$ & $\mathrm{M}$ & $(i)$ & $51 \%$ \\
$18 \mathrm{f}$ & $\mathrm{F}$ & $(i v)$ & $72 \%$ & $18 \mathrm{n}$ & $\mathrm{N}$ & $(i)$ & $54 \%$ \\
$18 \mathrm{~g}$ & $\mathrm{G}$ & $(i v)$ & $68 \%$ & $18 \mathrm{o}$ & $\mathrm{O}$ & $(i)$ & $12 \%$ \\
$18 \mathrm{~h}$ & $\mathrm{H}$ & $(i v)$ & $75 \%$ & $18 \mathrm{p}$ & $\mathrm{P}$ & $(i)$ & $12 \%$ \\
$18 \mathrm{i}$ & $\mathrm{I}$ & $(i v)$ & $69 \%$ & $18 \mathrm{q}$ & $\mathrm{Q}$ & $(i)$ & $42 \%$ \\
$18 \mathrm{j}$ & $\mathrm{J}$ & $(i)$ & $68 \%$ & $18 \mathrm{r}$ & $\mathrm{R}$ & $($ iii $)$ & $77 \%$ \\
\hline
\end{tabular}

${ }^{a}$ See Scheme 6 for conditions $(i)-(i v)$.

We next sought to generate a $2 \mathrm{D}$ library by further elaboration of Chemset 1 through reduction of the C9 carbonyl group of esters $\mathbf{1 5}$ to afford the corresponding hydroxy esters 19-30 (Scheme 7). 
Scheme 7. Synthesis of Chemset $3^{a}$
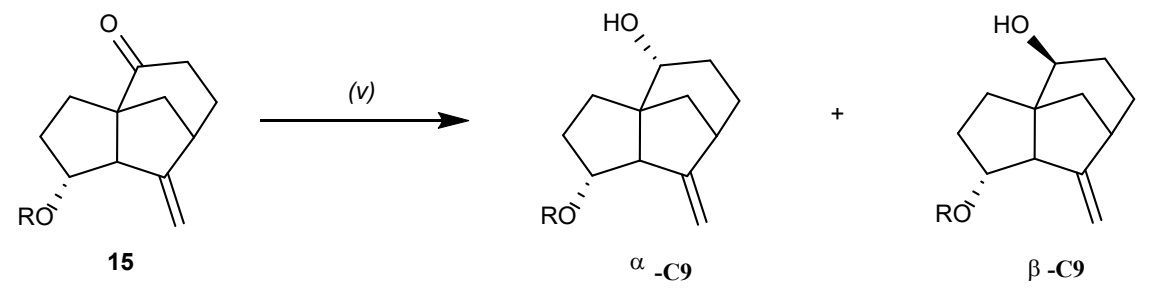

$\begin{array}{llll}\text { 19; } & \text { R: hydrogen } & 25 ; & \text { R: H } \\ 20 ; & \text { R: B } & 26 ; & \text { R: I } \\ 21 ; & \text { R: C } & 27 ; & \text { R: J } \\ 22 ; & \text { R: D } & 28 ; & \text { R: L } \\ 23 ; & \text { R: E } & 29 ; & \text { R: N } \\ 24 ; & \text { R: G } & 30 ; & \text { R: Q }\end{array}$

${ }^{a}(v)$ a: $\mathrm{NaBH}_{4}, \mathrm{MeOH}, 0{ }^{\circ} \mathrm{C}, 1 \mathrm{~h}$; b: $\mathrm{HCl}(0.35 \mathrm{~mol}), 10 \mathrm{~min}$.

Sodium borohydride reduction of the C9-carbonyl occurred in high yield (Table 3), however, this non-stereoselective reduction yielded both diastereomers. The configuration of the hydroxyl group generated in position 9 was determined by calculation of the dihedral angles (Figures S3 and S4) and confirmed by comparison of the spectral data with those of reported values ${ }^{43,44}$ Molecular modelling on compound $19 \alpha$ predicted a doublet of doublets for the $\beta$ $\mathrm{H}$ on $\mathrm{C} 9$ with $J$ values of $8.8 \mathrm{~Hz}$ and $7.1 \mathrm{~Hz}$ while the $J$ values for compound $\mathbf{1 9 \beta}$ were predicted to be $4.5 \mathrm{~Hz}$ and $2.0 \mathrm{~Hz}$. These predicted values correlate well with the observed values (dd; $10.3 \mathrm{~Hz}$ and $5.8 \mathrm{~Hz}$ for the compounds $19 \alpha$ and broad singlet; $2.6 \mathrm{~Hz}$ and $1.2 \mathrm{~Hz}$ for the compound 19ק). Separation of the diastereomeric pairs was carried out using silica gel column chromatography. Further purification using HPLC was also employed in some cases in order to achieve acceptable purity for biological screening. 
Table 3. Isolated yields for compounds in Chemset $3^{a, b}$

\begin{tabular}{ccccc}
\hline Compound & $\mathrm{R}$ & Procedure & Ratio $(\alpha: \beta)$ & Yield \\
\hline 19 & Hydrogen & $(v)$ & $62: 38$ & $87 \%$ \\
20 & $\mathrm{~B}$ & $(v)$ & $42: 58$ & $95 \%$ \\
21 & $\mathrm{C}$ & $(v)$ & $42: 58$ & $92 \%$ \\
22 & $\mathrm{D}$ & $(v)$ & $39: 61$ & $94 \%$ \\
23 & $\mathrm{E}$ & $(v)$ & $40: 60$ & $94 \%$ \\
24 & $\mathrm{G}$ & $(v)$ & $45: 55$ & $89 \%$ \\
25 & $\mathrm{H}$ & $(v)$ & $41: 59$ & $91 \%$ \\
26 & $\mathrm{I}$ & $(v)$ & $65: 35$ & $95 \%$ \\
27 & $\mathrm{~J}$ & $(v)$ & $44: 56$ & $96 \%$ \\
28 & $\mathrm{~L}$ & $(v)$ & $39: 61$ & $93 \%$ \\
29 & $\mathrm{~N}$ & $(v)$ & $43: 57$ & $89 \%$ \\
30 & $\mathrm{Q}$ & $(v)$ & $56: 44$ & $94 \%$ \\
\hline
\end{tabular}

${ }^{a}$ See Scheme 5 for condition $(v) .{ }^{b}$ See Scheme 4 for the structure of $\mathbf{2} 1 \alpha$ and $\mathbf{2 1 \beta}$.

\section{Biological Activity of the Synthesised Compounds in a PD Phenotypic Assay}

A phenotypic assay was used to test the biological profile of all synthesized compounds against normal and Parkinson's patient-derived hONS cells. Cells were treated with $10 \mu \mathrm{M}$ of each compound for $24 \mathrm{~h}$ in a 96 -well plate format. Cytological parameters were assessed by staining with fluorescent probes targeting various cellular pathways and organelles implicated in PD. These included mitochondria, early endosomes, lysosomes, microtubulebased cytoskeleton, and autophagosomes. The cellular markers including Dapi (nucleus), MitoTracker (mitochondria), LysoTracker (lysosome), anti $\alpha$-tubulin antibody (microtubule, cytosckeleton), anti EEA1 antibody (early endosomes) and anti LC3b antibody (autophagosomes) were used due to their significance in the biology of PD. In order to quantify the biological effects, 38 parameters from the combination of different fluorescent probes were used (Table S4). ${ }^{32}$ Comparative analyses were performed on the effect of compounds on the normal vs Parkinson's patient-derived cells followed by comparative analysis between of the effect of Chemsets against Parkinson's patient-derived cell line. None of the compounds used in the assay found to have cytotoxicity effect based on the total 
number of cells remaining after 24 hours of treatment with a compound. The stability of synthesized cedrane scaffold 14 and two ester derivatives 150 and $28 \beta$ was assessed under the phenotypic assay conditions (Figures S5-S7). The LC-MS results showed no evidence of hydrolyses of compounds $\mathbf{1 5 0}$ or $\mathbf{2 8} \boldsymbol{\beta}$ and cedrane scaffold $\mathbf{1 4}$ was stable under various evaluated conditions.

\section{Comparative analysis of the biological activity of synthesized compounds against}

\section{healthy and Parkinson's patient-derived cell lines}

Chemset 1: Most of the compounds in Chemset 1 showed a slightly higher negative effect on nucleus intensity marker of normal cell line compared to Parkinson's patient-derived cell, of which the 3-furoic ester derivative 15p showed the highest effect (Figure 8). The majority of compounds showed a larger negative effect on $\alpha$-tubulin markers of the normal cell line. Phenylacetic ester derivatives $\mathbf{1 5 g}$ displayed the highest effect on $\alpha$-tubulin markers PD patient while 15h displayed the highest effect on $\alpha$ - tubulin markers in the normal cell lines. For markers related to mitochondria the effects on PD patient cell line were stronger and positive for most of the derivatives, and compounds $\mathbf{1 5 n}$, with trifluoromethyl group, and 15q, with heteroatoms on the side chain, displayed the highest positive effects. The 3-furoic ester derivative 15p had the most significant positive effect on mitochondria of healthy cell line. The core scaffold 14, its derivatives with aliphatic side chains (compounds $\mathbf{1 5 a}$, 15b, 15 $\mathbf{c}^{\prime}, \mathbf{1 5 d}$ and $\left.15 \mathbf{e}\right)$ and compounds $15 \mathbf{h}, \mathbf{1 5 i}, \mathbf{1 5} \mathbf{j}$ and $\mathbf{1 5 k}$ displayed higher negative effects on LC3b markers of the healthy control cell line, of which compound 15e exhibited the strongest effect. The effects of most of the compounds on lysosome markers were generally negative for healthy control and positive for PD patient cell lines. All derivatives in this 


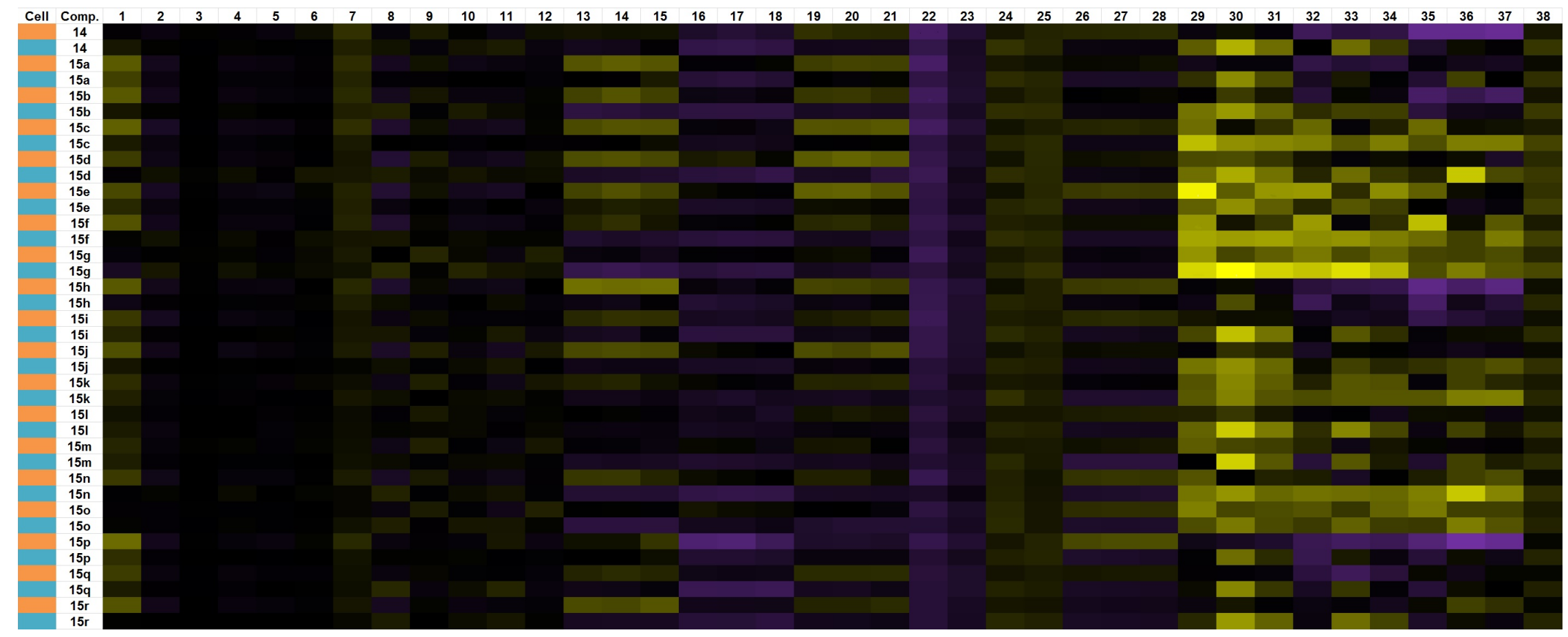

Figure 8. Heatmap depicting the cytological profile of compounds 14-15r of the Chemset 1 at $10 \mu \mathrm{M}$ on 38 parameters of normal (orange) and PD derived (blue) cell lines. The effects of compounds were plotted as log2 ratio to the DMSO control. Yellow shows a decrease versus control and purple shows an increase versus control. Individual compounds are presented on the $\mathrm{y}$-axis with individual features on the $\mathrm{x}$-axis. 1. Nucleus marker intensity mean $/ \mu \mathrm{m}^{2} \mathbf{2}$. Nucleus morphology area 3. Nucleus morphology roundness 4 . Nucleus morphology width $(\mu \mathrm{m})$ 5. Nucleus morphology length $(\mu \mathrm{m}) \mathbf{6}$. Nucleus morphology ratio width to length 7. Nucleus marker texture index SER spot 1 px 8. Cell morphology area 9. Cell morphology roundness index 10. Cell morphology width $(\mu \mathrm{m})$ 11. Cell morphology length $(\mu \mathrm{m}) \mathbf{1 2}$. Cell morphology ratio width to length $13 . \alpha$-Tubulin marker intensity mean $\mathbf{1 4}$. $\alpha$-Tubulin marker intensity outer region mean/ $\mu \mathrm{m}^{2}$ 15. $\alpha$-Tubulin marker intensity inner region mean $/ \mu \mathrm{m}^{2} \mathbf{1 6}$. Mitochondria marker intensity mean $\mathbf{1 7}$. Mitrochondria marker intensity outer region mean/ $\mu \mathrm{m}^{2} \mathbf{1 8}$. Mitrochondria marker intensity inner region mean $/ \mu \mathrm{m}^{2}$ 19. LC3b marker intensity mean $\mathbf{2 0}$. LC3b marker intensity outer region mean $/ \mu \mathrm{m}^{2} \mathbf{2 1}$. LC3b marker 
intensity inner region mean $/ \mu \mathrm{m}^{2}$ 22. Tubulin marker texture SER spot 1 px 23. Mitochondria marker texture SER spot 1 px 24 . LC3b marker texture SER spot 1 px 25. Lysosome marker texture SER spot 1 px 26. Lysosome marker intensity mean $\mathbf{2 7}$. Lysosome marker intensity outer region mean/ $\mathrm{m}^{2}$ 28. Lysosome marker intensity inner region mean $/ \mu \mathrm{m}^{2} \mathbf{2 9}$. Relative spot signal on cytoplasm 30. Number of spots on cytoplasm $\mathbf{3 1}$. Number of spots per area of cytoplasm $\mathbf{3 2}$. Relative spot signal on outer region 33. Number of spots on outer region $\mathbf{3 4}$. Number of spots per area of outer region $\mathbf{3 5}$. Relative spot signal on inner region $\mathbf{3 6}$. Number of spots on inner region 37. Number of spots per area of inner region 38. EEA1 marker texture SER spot 1 px. 
chemset except 15e showed a strong negative effect on the number and intensities of spot signal on cytoplasm markers of PD patient cell line.

Chemset 2: All compounds in Chemset 2 had negative effects on nucleus intensity marker of both cell lines, however, the effect was generally 1-3 fold higher for the normal cell line (Figure S8). The only compound that violated this pattern was compound $\mathbf{1 8 b}$ which showed the highest observed negative effect against PD patient cell line. Comparison of the activity of compounds on $\alpha$-tubulin markers of normal cell line vs PD Patient cell line showed that they are not following a general pattern. Compounds $\mathbf{1 8 b}, \mathbf{1 8 k}$ and $18 \mathrm{l}$ displayed a high positive effect on $\alpha$-tubulin markers of PD patient cell line and compounds 18o, 18p, 18q and 18r had high negative effects on $\alpha$-tubulin markers of normal cell line. The markers related to lysosome have been positively affected by most of the compounds but the effect was stronger for PD cell line. All derivatives in this Chemset had shown a stronger (2-4 fold) negative effect on number of spot signal on cytoplasm marker of PD patient cell line only. The strongest effect on this marker was observed for the core scaffold, compound 17.

Chemset 3 ( $\boldsymbol{\alpha}$-C9 and $\boldsymbol{\beta}$-C9): Comparative analysis of the biological activity of the synthesized compounds in Chemset 3 ( $\alpha$-C9 and $\beta$-C9) against control cell line $v s$ PD patientderived cell line (Figure S9) revealed the following general pattern: 1) Most of the compounds did not have significant effects on nucleus and cell morphology markers of both cell lines; 2) There are stronger effects (2-3 fold) for most of the compounds on $\alpha$-tubulin, mitochondria, LC3b markers of normal cell line; 3) Most of the compounds showed a stronger effect on lysosome markers of PD patient cell line; 4) Most of the compounds showed a stronger negative effect (2-5 fold) on the number of spots on cytoplasm marker of PD patient cell line. In addition, the $m$-fluoro phenylacetic ester derivative, compound $\mathbf{2 5} \boldsymbol{\alpha}$, 
exhibited significant negative effects on $\alpha$-tubulin and LC3b markers and positive effects on number and intensities of EEA1 marker of only normal cell line. Amongst the $\boldsymbol{\alpha}$ series of Chemset 3, compound $29 \alpha$ displayed considerably strong effects on the vast majority of the biological markers of both normal and PD patient cell lines. Compound 29a showed the strongest negative effects on nucleus intensity, $\alpha$-tubulin, mitochondria, LC3b and lysosome markers and also strongest positive effects on cell morphology area, number of spots on cytoplasm as well as number of spots on outer and inner regions. In $\boldsymbol{\beta}$ series, compound $\mathbf{2 7 \boldsymbol { \beta }}$ displayed considerably strong effects on the vast majority of the biological markers of the normal and PD patient cell lines. It showed the strongest negative effects on nucleus intensity, $\alpha$-tubulin, mitochondria, LC3b, lysosome and relative spot signal on inner region markers and strongest positive effects on cell morphology area, number of spots on cytoplasm and also number of spots on outer and inner regions.

\section{Comparative analysis of the biological profile of synthesised compounds against Parkinson's patient-derived cell line}

Chemset $1 v$ Chemset 2: The biological effect of compounds in Chemset 1 and their diastereomers in Chemset 2 on the biological markers (38 parameters) of PD patient cell line are compared in Figure 9. Comparative analysis of the biological activity of Chemsets 1 and 2 revealed the following observations for both Chemsets: 1) Small negative effect on nuclear and cell morphology markers; 2) Moderate positive effects on $\alpha$-tubulin, mitochondria, LC3b and lysosome markers; 3) Negative effect for most of compounds in both Chemsets on number and intensities of EEA1 markers.

In addition to the above mentioned similarities some interesting differences between the biological effects of compounds in Chemset 1 and their stereoisomers in Chemset 2 were 


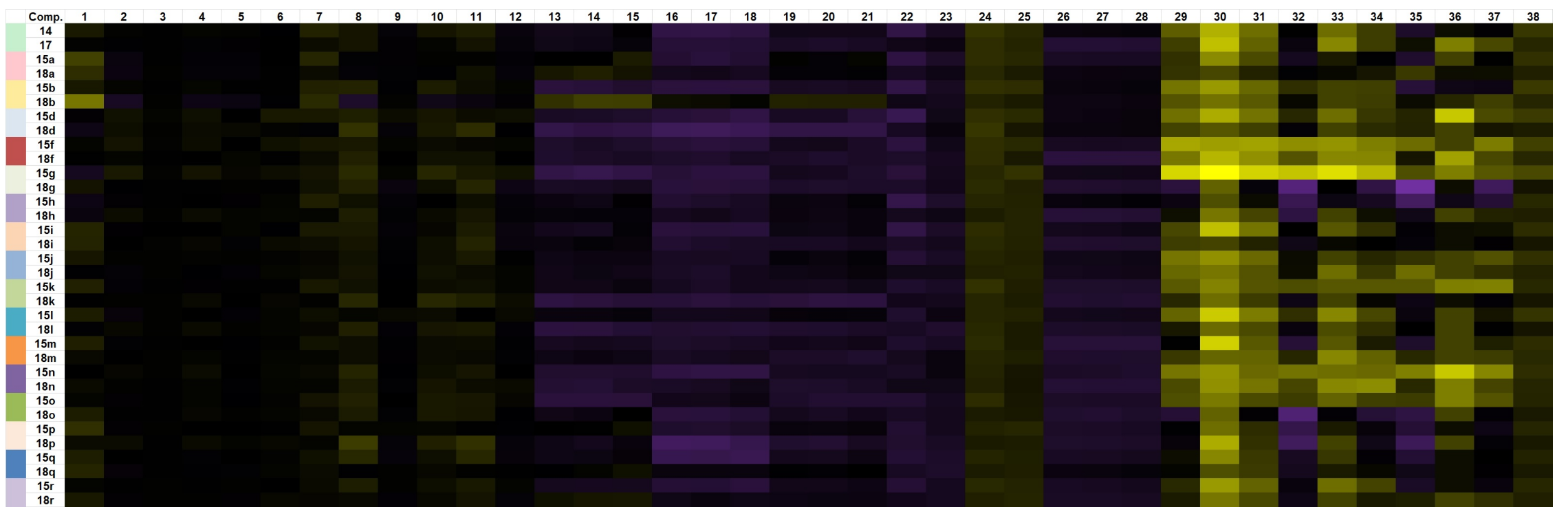

Figure 9. Heatmap depicting the comparative cytological profile of compounds 14-15r of Chemset 1 and $\mathbf{1 7 - 1 8 r}$ of the Chemset 2 at $10 \mu \mathrm{M}$ on 38 parameters of Parkinson's patient-derived cell lines. The effects of compounds were plotted as $\log 2$ ratio to the DMSO control. Yellow shows a decrease versus control and purple shows an increase versus control. Individual compounds are presented on the y-axis (compounds with same derivatives are shown with the same colour) with individual features on the x-axis. For the features descriptions refer to Figure 8. 
noticed. The core scaffold $\mathbf{1 4}$ displayed 4-fold stronger effect on $\alpha$-tubulin marker texture SER spot 1 px while its diastereomer in Chemest 2, compound 17, showed 3 and 5 times higher effects on lysosome and number of spot on inner region, respectively. Compound 15a exhibited a negative effect on relative spot signal on inner region, whereas compound 18a, had the reverse positive effect. Compound $\mathbf{1 8 b}$ had a 5-fold stronger effect on nucleus marker intensity mean compared to its diastereomer in Chemset 1, compound 15b. Furthermore, compound $\mathbf{1 5 b}$ displayed moderate positive effect on $\alpha$-tubulin and mitochondria markers while compound $\mathbf{1 8 b}$ showed small negative effects. There was a 2fold positive effect on $\alpha$-tubulin, mitochondria and LC3b markers for compound 18d and a double size negative effect on number and intensities of EEA1 markers for compound 15d. The $m$-flouro phenylacetic ester $\mathbf{1 5 g}$ compared to its diastereomer $\mathbf{1 8 g}$ had a stronger effect (2-5 times more) on markers related to $\alpha$-tubulin and number and intensities of EEA1 but the effect was reversed for relative spot signal on inner region and number of spots per area of inner region markers for which compound $\mathbf{1 8 g}$ had stronger effect. Compound $\mathbf{1 8 h}$ showed 3 times stronger effects on lysosome marker while its diastereomer, derivative $\mathbf{1 5 h}$, had a 6 fold stronger positive effect on relative spot signal on inner region. Compound 18k exhibited a 2-fold effect compared to $\mathbf{1 5 k}$ on markers related to $\alpha$-tubulin, mitochondria and LC3b. Derivative 18I compared to its diastereomer in Chemset 1, derivative 15l, had a 3 times stronger effect on $\alpha$-tubulin and LC3b whereas $\mathbf{1 5 l}$ showed double size effect on relative spot signal on cytoplasm and number of spots on cytoplasm. While compound $\mathbf{1 5 n}$ showed a stronger effect on LC3b marker, its distereomer 18n had stronger effects on relative spot signal on inner region, number of spots on inner region and number of spots per area of inner region markers. The 2-furoic ester derivative in Chemset 1, compound 15o, displayed 3-fold 
stronger effect on $\alpha$-tubulin whereas the diastereomer $\mathbf{1 8 0}$ showed a 3-fold stronger effect on mitochondria marker. The 3-furoic ester derivatives $15 p$ and 18p, exhibited different size effects on many parameters. Markers related to cell morphology area and length, LC3b, mitochondria, numbers of spots on cytoplasm and inner region have been affected by compound $\mathbf{1 8 p}$ two fold more strongly than compound $\mathbf{1 5 p}$. The ester $\mathbf{1 5 q}$ in comparison to its diastereomer 18q had stronger effects (4 times more) on markers related to mitochondria. There was a weak negative effect on $\alpha$-tubulin markers caused by compound $\mathbf{1 8} \mathbf{r}$ while the effect on these markers was positive for compound 15r. The observed different pattern of biological profile between diastereomers in Chemsets 1 and 2 highlights the important role of both stereochemistry and substituted groups at C-3 of the scaffold on biological activity.

Chemsets $1 v$ Chemset 3 [( $\alpha-\mathbf{C} 9)$ and ( $\beta$-C9)]: The effect of compounds in Chemset 1 and their diastereomers in Chemset $3[(\alpha-C 9)$ and $(\beta-C 9)]$ on the 38 biological markers of Parkinson's patient-derived cell line are depicted in Figure 10. Comparison of the biological activity of Chemsets 1 and 3 showed the following trends: 1) Except for compounds $27 \boldsymbol{\beta}$ and 29a, no considerable effects on parameters related to nucleolus and cell morphology was observed for all compounds; 2) Positive effect on mitochondria markers was noticed for all compounds except for compounds $24 \beta, 26 \alpha, 27 \beta$ and $29 \alpha ; 3$ ) Four times stronger positive effect was observed for compounds in Chemset 1 compared to their diasteromers in Chemset $3[(\alpha-C 9)$ and $(\beta-C 9)] ; 4)$ All compounds had negative effect on mitochondria and LC3B texture SER spot 1 px markers; 5) Except for compounds $27 \boldsymbol{\beta}$ and $29 \alpha$, positive effect on lysosome markers was observed for all compounds; 6) Negative effect on number of spots on cytoplasm and inner region markers was observed for all compounds except for compounds $27 \beta$ and $29 \alpha$. 
In addition, the following differences between the biological effects of compounds in Chemest 1 and their stereoisomers in Chemest 3 were observed. The reduction of carbonyl group in the core scaffold 14 led to an increase in the effect caused by $19 \alpha$ and $19 \beta$ on nucleus intensity mean, lysosome and number of spots on inner region markers. On the other hand, distereomers $19 \alpha$ and $19 \beta$ showed 4 times lower effect on mitochondria markers compared to the oxidized form, compound 14 . Compound $19 \alpha$ showed a moderate positive effect on relative spot signal on outer region while the observed effect for its diastereomer $19 \beta$ was negative. Compound $15 b$, compared to its oxidized form, compounds $20 \alpha$ and $20 \beta$, showed 3 times larger effect on mitochondria, relative spot signal on cytoplasm and inner region markers. The biological markers related to $\alpha$-tubulin and LC3b have been affected equally by $\mathbf{1 5 b}$ and $\mathbf{2 0 \beta}$ and that was 3 times stronger compared to what observed for compound 20a. Compound 15c' compared to its reduced forms in Chemset 3, distereomers $21 \alpha$ and 21及, showed stronger effects on number and intensities of EEA1 markers. Compound $21 \alpha$ displayed moderate negative effects on $\alpha$-tubulin, LC3b and large positive effect on relative spot signal on outer and inner regions which is opposite to the effect observed for the diasteroemers $\mathbf{1 5} \mathbf{c}^{\prime}$ and $\mathbf{2 1 \beta}$. There was an increased effect for the reduced forms of compound $\mathbf{1 5 d}$, derivatives $\mathbf{2 2} \alpha$ and $\mathbf{2 2 \beta}$, on nucleus intensity mean marker, while for the markers related to $\alpha$-tubulin, LC3b, number of spots on inner region, number of spots per area of inner region and also EEA1 marker texture SER spot 1 px, the observed effect for the oxidized form, compound 15d, was 1-4 times stronger. Compounds $\mathbf{1 5 d}$ and $\mathbf{2 2 \beta}$ displayed negative effect on relative spot signal on cytoplasm, number and relative spot signal on outer and inner region but the effect observed for derivative $\mathbf{2 2 \alpha}$ on these parameters was positive. 


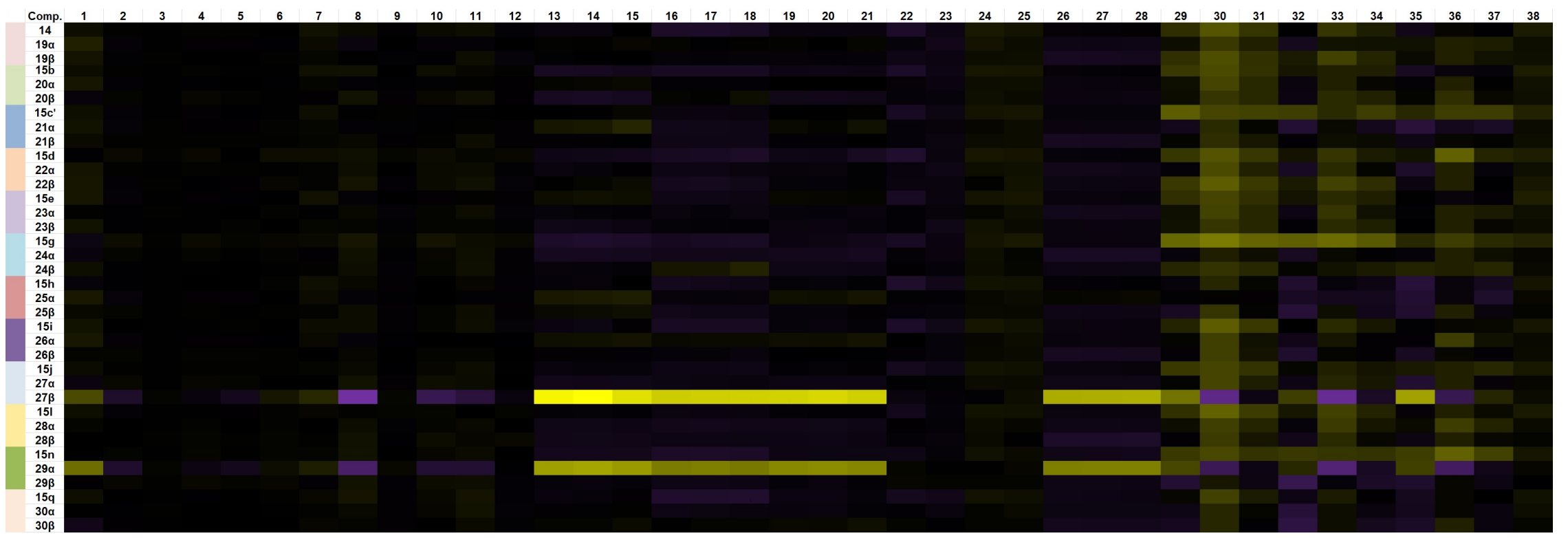

Figure 10. Heatmap depicting the comparative cytological profile of compounds 14-15q of Chemset $1, \mathbf{1 9 \alpha - 3 0 \alpha}$ of the Chemset $3(\alpha-C 9)$ as well as 19-30 $\beta$ of the Chemset $3(\beta-C 9)$ at $10 \mu \mathrm{M}$ on 38 parameters of Parkinson's patient-derived cell lines. The effects of compounds were plotted as log2 ratio to the DMSO control. Yellow shows a decrease versus control and purple shows an increase versus control. Individual compounds are presented on the y-axis with individual features on the x-axis. For the features descriptions refer to Figure 8. Compounds with same derivatives are shown with the same colour. 
Compounds 15e and its reduced forms in Chemset 3, diastereomers $\mathbf{2 3 \alpha}$ and $\mathbf{2 3 \beta}$, displayed a similar size and type of effect on most of the parameters except the observed four fold higher effects on $\alpha$-tubulin markers for compounds $\mathbf{2 3} \boldsymbol{\alpha}$ and $\mathbf{2 3} \boldsymbol{\beta}$. The reduction of the carbonyl group in compound $\mathbf{1 5 g}$ led to considerable decrease (3-8 fold) for compound $\mathbf{2 4 \alpha}$ and $\mathbf{2 4 \beta}$ on the parameters related to number and intensities of EEA1 markers. Furthermore, compound 15g showed higher effect on $\alpha$-tubulin markers. Compounds 15g and $\mathbf{2 4 \alpha}$ had positive effect on mitochondria markers while the effect was negative for compound $\mathbf{2 4 \boldsymbol { \beta }}$. A negative effect was observed for compound $\mathbf{2 5 \alpha}$ on $\alpha$-tubulin and LC3B markers while the effect observed for its diastereomer in Chemset 3, compound $\mathbf{2 5 \boldsymbol { \beta }}$, and its oxidized form in Chemset 1, compound $\mathbf{1 5 h}$, was reversed. Compound 15i displayed 4 times higher effects compared to compounds $26 \boldsymbol{\alpha}$ and $\mathbf{2 6 \boldsymbol { \beta }}$ on mitochondria markers and also had significant negative effects on number and relative spot on cytoplasm.

The benzoic acid derivative in Chemset 3 ( $\beta$-C9), compound $\mathbf{2 7} \boldsymbol{\beta}$, had considerably strong effects (3-20 fold stronger) across all parameters compare to its oxidized form in Chemset 1 , compound $\mathbf{1 5 j}$, and also its diasteromer in Chemset $3(\alpha-C 9)$, compound 27 $\boldsymbol{\alpha}$. In fact, this compound revealed the highest observed effect on most biological markers among the 60 synthesized compounds. The reduction of the carbonyl group in compound 15l resulted in increasing the effect on markers related to $\alpha$-tubulin, mitochondria and LC3b as was observed for compounds $\mathbf{2 8 \alpha}$ and $\mathbf{2 8 \beta}$. However, the reduced forms, diastereomers $\mathbf{2 8 \alpha}$ and $\mathbf{2 8 \boldsymbol { \beta }}$, showed less negative effect on number and relative spot on cytoplasm. In addition, compound $\mathbf{2 8 \beta}$ exhibited twice positive effect on lysosome markers compare to $\mathbf{2 8 \alpha}$.

The 3-fluoro-5- trifluoromethyl derivative $29 \alpha$ compared to its diasteromer $29 \beta$ and its oxidized form $\mathbf{1 5 n}$, displayed very strong effects on most of the measured biological 
markers. The marker related to relative spot signal on outer region was the only parameter that had been positively affected by compound 29ק. Reduction of compound 15q caused a decrease in the observed effect on mitochondria and number of spots on cytoplasm markers and doubled the effect on markers related to spot signal on outer region for compounds $\mathbf{3 0 \alpha}$ and $\mathbf{3 0 \beta}$.

Overall, in comparison to Chemset 1 , the effects of compounds in Chemset 3 were stronger across most of the parameters. This means that the reduced form of scaffold in position C-9 is important for biological activity. Furthermore, the different pattern of biological profile between $(\alpha-\mathrm{C} 9)$ and $(\beta-\mathrm{C} 9)$ diastereomers in Chemset 3 revealed that the stereochemistry of the hydroxy group in position C-9 is also playing an important role in interaction with enzymes and therefor biological activity.

\section{CONCLUSION}

Natural products as a source of non-flat scaffolds offer an opportunity to cover neglected areas of biological space. A chemoinformatic analysis was developed to identify non-flat scaffolds embedded in natural products within the DNP. Manual selection based on recognizing non-flat scaffolds that direct substituents in 3D space gave the cedrane scaffold as an example. The presented protocol offers opportunity for automation to analyse the 6,102 natural product derived scaffolds identified from the chemoinformatic study. Synthesizing diverse natural product-like libraries, based on 3D (non-flat) natural product scaffolds that maintain the $3 \mathrm{D}$ orientations during biosynthesis can explore uncovered portions of biologically relevant chemical space. A synthetic approach, adapted from the literature, was employed to achieve $5 \mathrm{~g}$ of a cedrane scaffold that had 3 points of attachments allowing future generation of $1 \mathrm{D}, 2 \mathrm{D}$ and $3 \mathrm{D}$ libraries covering more than $50 \%$ of the natural diversity of natural products 
with an embedded cedrane scaffold. Calculation of key physicochemical and structural properties revealed that NP Chemsets 1-3 have values that are within range of generally acceptable values for drug-likeness.

The structure activity relationship analysis of the compounds within or between Chemsets demonstrated, as expected, that changing the functionality and stereochemistry of sidechains can have a dramatic effect on biological activity. These results are consistent with the hypothesis that a 3D scaffold can serve to direct substituents in $3 \mathrm{D}$ space in order to interact with biological targets and highlights the importance of scaffold selection in drug discovery. Compound 15g in Chemset 1 and compound 17 as a core scaffold in Chemset 2 and their derivatives with aromatic side chains, compounds $\mathbf{1 8 f}$ and $\mathbf{1 8 p}$, showed some selective activity for markers related to $\alpha$-tubulin, mitochondria, lysosome and EEA1 markers of Parkinson's patient-derived cell line compared to the normal cell line.

\section{EXPERIMENTAL SECTION}

\section{Molecular Modelling Study}

Dictionary of Natural Products (sdf version 211.9) was used for chemoinformatic analysis in scaffold abstraction. All the computational work was performed in Macromodel Maestro-Schrödinger version 9.7. For energy calculations including multi-minimization and conformational search OLPS-2005 force field was employed. A mixed torsional/low-mode sampling method was used in conformational search and only one conformer with minimum energy was kept in project table as the best conformer. To renumber atoms in cedrane scaffold, Chem \& Bio 3D 12.0 software was used. X-Clustering was performed using 
Atomic RMSD as the distance criterion. An average linkage method was used for clustering of molecules based on the scaffold heavy atoms.

\section{General Experimental Details}

LC-MS spectra were obtained using either a Waters ZQ electrospray mass spectrometer with a Phenomenex Luna $\mathrm{C}_{18}$ column $(4.6 \times 50 \mathrm{~mm}, 3 \mu \mathrm{m})$ for purity check or a Thermo $^{\mathrm{TM}}$ UltiMate 3000 HPLC system equipped with MSQ Plus mass detector with a Accucore $^{\mathrm{TM}} \mathrm{C}_{18}$ column $(2.1 \times 150 \mathrm{~mm}, 2.6 \mu \mathrm{m})$ for stability test. Analytical HPLC was performed with a Phenomenex Onyx Monolithic $\mathrm{C}_{18}$ column (4.6 x $\left.100 \mathrm{~mm}\right)$. A Betasil $\mathrm{C}_{18}$ column $(21.2 \times 150 \mathrm{~mm})$ was used for semi-preparative HPLC separation. All HPLC and LC-MS experiments were performed with $\mathrm{MeOH}-\mathrm{H}_{2} \mathrm{O}$ gradient solvent system. Milipore Milli-Q PF filtered $\mathrm{H}_{2} \mathrm{O}$ and HPLC grade solvents were used for chromatography. NMR spectra were recorded at $30{ }^{\circ} \mathrm{C}$ on Varian $400 \mathrm{MHz}, 500 \mathrm{MHz}$ and $600 \mathrm{MHz}$ spectrometers. ${ }^{1} \mathrm{H}$ NMR spectra were referenced to either tetramethylsilane or residual isotopomer with one less deuterium of the perdeuterated

solvent. ${ }^{1} \mathrm{H}$ NMR data reported as chemical shift in parts per million (ppm), relative integral, multiplicity (designated as s, singlet; br s, broad singlet; d, doublet; dd, doublet of doublets; t, triplet; q, quartet; and m, multiplet), coupling constants $J$ are reported in Hz. ${ }^{13} \mathrm{C}$ NMR chemical shifts are reported in ppm and referenced to solvent resonance. All reactions were conducted under an inert atmosphere $\left(\mathrm{N}_{2}(\mathrm{~g})\right.$ or $\left.\operatorname{Ar}(\mathrm{g})\right)$ unless otherwise stated. Glassware was either oven dried or flame dried under vacuum prior to use. Commercially available chemicals were used as purchased or purified using standard procedures by Armarego et al ${ }^{45}$ Reactions at $0{ }^{\circ} \mathrm{C}$ or $-78{ }^{\circ} \mathrm{C}$ were conducted by respectively cooling the reaction vessel in baths of ice and water or dry ice and acetone. Anhydrous tetrahydrofuran was obtained from Pure Solve solvent distillation apparatus. Thin layer chromatography (TLC) was performed on Merck Kieselgel 60 
F254 pre-coated aluminium sheets. Column chromatography was performed on Merck Kieselgel 60 (230-400 mesh) or Davisil Chromatographic Silica Media (LC60A 40-63 micron). HPLC grade solvents were used for column chromatography. A combination of ${ }^{1} \mathrm{H}$ NMR, LC-UV and LC-MS was used to confirm $\geq 95 \%$ purity of the compounds prior to biological assay.

\section{Synthesis of Cedrane Scaffold}

3-Methyl anisole (8). To a solution of $m$-cresol (60 g, $555 \mathrm{mmol})$ in acetone (400 $\mathrm{mL})$ where added anhydrous $\mathrm{K}_{2} \mathrm{CO}_{3}(102 \mathrm{~g}, 738 \mathrm{mmol})$ and iodomethane $(104.8$ $\mathrm{g}, 738 \mathrm{mmol})$. The mixture was heated at reflux $\left(72^{\circ} \mathrm{C}\right)$ under argon for $24 \mathrm{~h}$. After cooling the reaction to room temperature, the solution was filtered with Celite, washed with acetone, and concentrated under reduced pressure. The residue was dissolved in dichloromethane and washed with $2 \mathrm{M} \mathrm{NaOH}$. Further simple distillation afforded pure $m$-methylanisole as a pale yellow liquid $(57 \mathrm{~g})$ in $85 \%$ yield; ${ }^{1} \mathrm{H}$ NMR $\left(500 \mathrm{MHz}, \mathrm{CDCl}_{3}\right) \delta 7.20(\mathrm{t}, \mathrm{J}=7.63 \mathrm{~Hz}, 1 \mathrm{H}), 6.84(\mathrm{~d}, J=7.6$ $\mathrm{Hz}, 1 \mathrm{H}), 6.78(\mathrm{~s}, 1 \mathrm{H}), 6.77(\mathrm{~d}, J=7.6 \mathrm{~Hz}, 1 \mathrm{H}), 3.82(\mathrm{~s}, 3 \mathrm{H}), 2.37(\mathrm{~s}, 3 \mathrm{H})$.

1-methoxy-5-methylcyclohexa-1,4-diene (9). Sodium (15 g, 0.654 g-atom) was added in small pieces over $1 \mathrm{~h}$ to a stirred solution of $m$-methylanisole $(20 \mathrm{~g}$, $163.6 \mathrm{mmol}), t$-BuOH $(82 \mathrm{~mL})$, and THF $(82 \mathrm{~mL})$ in liquid ammonia $(400 \mathrm{~mL})$. After stirring for $30 \mathrm{~min}$, methanol was added drop-wise and the ammonia was allowed to evaporate under $\mathrm{N}_{2}$. Then water and diethyl ether were added, the organic phase was separated, the aqueous phase was extracted with fresh ether, and the combined organic phases were washed with a saturated brine solution and then dried (anhydrous $\mathrm{MgSO}_{4}$ ). The organic solvent was evaporated and the residue distilled to give diene 9 (14 g) in 70\% yield without further purification. ${ }^{1} \mathrm{H}$ NMR (500 MHz, CD $\left.3 \mathrm{OD}\right) \delta 5.37$ (br s, 1H), 4.64 (br s, 1H), 3.52 (s, 3H), 2.73 
(br s, 2H), $2.56(\mathrm{t}, \mathrm{J}=7.63,2 \mathrm{H}), 1.67(\mathrm{~s}, 3 \mathrm{H}) ;{ }^{13} \mathrm{C} \mathrm{NMR}\left(125 \mathrm{MHz}, \mathrm{CD}_{3} \mathrm{OD}\right) \delta$ $154.2,131.4,119.9,91.3,54.2,34.0,27.8,23.1$.

l-Methoxy-2-cyano-5-methylbicyclo[2.2.2]oct-5-ene (11). A mixture of diene 9 $(1.0 \mathrm{~g}, 0.008 \mathrm{~mol})$, acrylonitrile $(0.841 \mathrm{~g}, 0.015 \mathrm{~mol})$, and hydroquinone $(0.2 \mathrm{mg})$ was placed in a glass pressure vessel and heated at $120{ }^{\circ} \mathrm{C}$ for $16 \mathrm{~h}$. Purification of the crude residue by silica gel column chromatography $(2: 5$ diethylether/hexane) gave nitrile $11(0.75 \mathrm{~g})$ in $52 \%$ yields. ${ }^{1} \mathrm{H}$ NMR (500 MHz, $\left.\mathrm{CD}_{3} \mathrm{OD}\right) \delta 5.91(\mathrm{~s}, 1 \mathrm{H}), 3.38(\mathrm{~s}, 1 \mathrm{H}), 3.09(\mathrm{dd}, \mathrm{J}=10.1,4.3 \mathrm{~Hz}, 1 \mathrm{H}), 2.39(\mathrm{~d}, \mathrm{~J}=$ $1.2 \mathrm{~Hz}, 1 \mathrm{H}), 2.13(\mathrm{~m}, 1 \mathrm{H}), 1.87(\mathrm{~d}, \mathrm{~J}=1.6 \mathrm{~Hz}, 1 \mathrm{H}), 1.71-1.49(\mathrm{~m}, 2 \mathrm{H}), 1.46-1.38$ $(\mathrm{m}, 1 \mathrm{H}) ;{ }^{13} \mathrm{C}$ NMR $\left(125 \mathrm{MHz}, \mathrm{CD}_{3} \mathrm{OD}\right) \delta 145.3,125.8,123.3,79.6,51.1,35.6$, $34.7,33.1,28.3,25.8,20.0$.

l-Methoxy-5-methylbicyclo[2.2.2] diisopropylamide, solution was prepared in 5 eq. by the drop-wise addition of $n$ butyllithium (2.05 M, $160 \mathrm{~mL}, 0.33 \mathrm{~mol})$ to diisopropylamine (34 mL, $0.24 \mathrm{~mol})$ in dry THF at $0{ }^{\circ} \mathrm{C}$. Then a solution of nitrile $11(10 \mathrm{~g}, 0.056 \mathrm{~mol})$ in dried THF (50 mL) was added drop-wise at $-78^{\circ} \mathrm{C}$ in to the LDA solution, under Ar. After stirring for $1 \mathrm{~h}$, oxygen (dried by passing through $\mathrm{KOH}$ tower) was bubbled into the lithionitrile solution at $-78{ }^{\circ} \mathrm{C}$ for $5 \mathrm{~h}$. The reaction was quenched with $1 \mathrm{M}$ sodium sulfite $(60 \mathrm{~mL})$ and allowed to stir for $30 \mathrm{~min}$ at $0{ }^{\circ} \mathrm{C}$ and then for $16 \mathrm{~h}$ at room temperature. The reaction mixture was extracted with ether ( 5 times) and the organic layer washed with $2 \mathrm{~N} \mathrm{NaOH}$ and saturated brine solution and then dried over $\mathrm{MgSO}_{4}$. Compound 12 was purified by chromatography on silica gel in $75 \%$ yield $(6.9 \mathrm{~g}) .{ }^{1} \mathrm{H}$ NMR $\left(500 \mathrm{MHz}, \mathrm{CD}_{3} \mathrm{OD}\right) \delta 5.80(\mathrm{~s}, 1 \mathrm{H}), 3.47(\mathrm{~s}, 3 \mathrm{H})$, $2.64(\mathrm{dd}, \mathrm{J}=5.0,2.6 \mathrm{~Hz}, 1 \mathrm{H}), 2.11-2.07(\mathrm{~m}, 1 \mathrm{H}), 1.84(\mathrm{~d}, \mathrm{~J}=1.6 \mathrm{~Hz}, 3 \mathrm{H}), 1.80-$ 
$1.67(\mathrm{~m}, 2 \mathrm{H}), 1.65-1.57(\mathrm{~m}, 1 \mathrm{H}) ;{ }^{13} \mathrm{C} \mathrm{NMR}\left(125 \mathrm{MHz}, \mathrm{CD}_{3} \mathrm{OD}\right) \delta 210.2,145.8$, $121.6,84.6,53.1,40.0,37.0,27.4,24.9,20.4$.

2-[(1,3-Dioxane-2-yl)ethyl]-4-methoxy-6-methylbicyclo-[2.2.2]oct-5-en-2 (13). To a fresh surface (crushed under Ar) of magnesium turnings (600 mg, $25 \mathrm{mmol}$ ) was added THF $(10 \mathrm{~mL})$ and catalytic amount of 1,2-dibromoethane (150 $\mu \mathrm{L})$ and the mixture was sonicated for $30 \mathrm{~s}$. To this mixture, a solution of 2-(2bromoethyl)-1,3-dioxane $(2.38 \mathrm{~mL}, 17.5 \mathrm{mmol})$ in dry THF (18 mL) was added over $2 \mathrm{~h}$. Then a solution of ketone $12(830 \mathrm{mg}, 5 \mathrm{mmol})$ in dry THF (10 mL) was added dropwise at $0{ }^{\circ} \mathrm{C}$ to the Grignard reagent solution. After $1.5 \mathrm{~h}$, the mixture was quenched with saturated aqueous $\mathrm{NH}_{4} \mathrm{Cl}$ solution, extracted with EtOAc, washed with brine, and dried over $\mathrm{MgSO}_{4}$. The organic layer was concentrated in vacuo, and the residue was purified by silica gel chromatography $(\mathrm{Hex} /$ EtOAc $=7: 1)$ to afford endo 13a $(760 \mathrm{mg})$ in $54 \%$ yield and exo alcohol 13b (460 mg) in 33\% yield. endo-Alcohol 13a: ${ }^{1} \mathrm{H}$ NMR (500 MHz, pyridine) $\delta$ $5.93(\mathrm{~s}, 1 \mathrm{H}), 4.58(\mathrm{t}, \mathrm{J}=5.1 \mathrm{~Hz}, 1 \mathrm{H}), 3.99(\mathrm{dd}, \mathrm{J}=11.8,4.4 \mathrm{~Hz}, 2 \mathrm{H}), 3.70-3.54$ (m, 2H), $3.36(\mathrm{~s}, 3 \mathrm{H}), 2.40(\mathrm{ddd}, \mathrm{J}=17.3,11.9,4.0 \mathrm{~Hz}, 2 \mathrm{H}), 2.29-2.20(\mathrm{~m}, 1 \mathrm{H})$, $2.19(\mathrm{~s}, 1 \mathrm{H}), 2.07-1.87(\mathrm{~m}, 2 \mathrm{H}), 1.87-1.78(\mathrm{~m}, 1 \mathrm{H}), 1.77-1.60(\mathrm{~m}, 6 \mathrm{H}), 1.57-$ $1.43(\mathrm{~m}, 1 \mathrm{H}), 1.40(\mathrm{~d}, \mathrm{~J}=11.6 \mathrm{~Hz}, 1 \mathrm{H}), 1.08(\mathrm{~d}, \mathrm{~J}=13.3 \mathrm{~Hz}, 1 \mathrm{H}) .{ }^{13} \mathrm{C}$ NMR $(125$ $\mathrm{MHz}$, pyridine) $\delta 135.6,125.3,105.6,82.5,78.1,65.2,51.3,40.8,36.7,33.5$, 28.1, 27.8, 25.1, 22.9, 20.5. exo-Alcohol (13b): ${ }^{1} \mathrm{H}$ NMR (500 MHz, pyridine) $\delta$ $6.10(\mathrm{~s}, 1 \mathrm{H}), 4.68(\mathrm{~d}, \mathrm{~J}=5.1 \mathrm{~Hz}, 1 \mathrm{H}), 4.07(\mathrm{ddd}, \mathrm{J}=16.1,12.0,6.0 \mathrm{~Hz}, 2 \mathrm{H})$, 3.76-3.63 (m, 2H), $3.42(\mathrm{~s}, 3 \mathrm{H}), 2.40(\mathrm{tdd}, \mathrm{J}=14.0,9.4,4.7 \mathrm{~Hz}, 2 \mathrm{H}), 2.18(\mathrm{~s}$, $1 \mathrm{H}), 2.12-1.93(\mathrm{~m}, 2 \mathrm{H}), 1.83-1.68(\mathrm{~m}, 5 \mathrm{H}), 1.66-1.50(\mathrm{~m}, 3 \mathrm{H}), 1.43(\mathrm{ddd}, \mathrm{J}=$ 14.6, 7.3, $5.0 \mathrm{~Hz}, 1 \mathrm{H}), 1.31(\mathrm{ddd}, \mathrm{J}=12.1,8.5,4.1 \mathrm{~Hz}, 1 \mathrm{H}), 1.17-1.09(\mathrm{~m}, 1 \mathrm{H})$. 
${ }^{13} \mathrm{C}$ NMR (125 MHz, pyridine) $\delta 135.7,125.8,105.3,78.2,63.8,52.1,43.1,35.9$, $32.5,29.1,27.5,26.8,25.1,24.6,20.3$.

Tricyclic ketone (14), Cedrane Scaffold. A mixture of alcohols 13a and b (2.5 $\mathrm{g}, 8.86 \mathrm{mmol})$ and $p$-TsOH. $\mathrm{H}_{2} \mathrm{O}(1.49 \mathrm{~g}, 7.83 \mathrm{mmol})$ was refluxed in acetone $(215 \mathrm{~mL}, 0.04 \mathrm{M})$ for $16 \mathrm{~h}$. The reaction mixture was quenched with saturated aqueous $\mathrm{NaHCO}_{3}$ solution, and the acetone was removed in vacuo. The reaction was extracted with EtOAc, washed with brine and then dried over $\mathrm{MgSO}_{4}$. The organic layer was concentrated in vacuo and the residue was purified by silica gel column chromatography $(\mathrm{Hex} / \mathrm{EtOAc}=7: 1)$ to obtain ketone 14 as a white powder $(1.1 \mathrm{~g})$ in $65 \%$ yield; m.p.: $79-81{ }^{\circ} \mathrm{C},{ }^{1} \mathrm{H}$ NMR $\left(500 \mathrm{MHz}, \mathrm{CDCl}_{3}\right) \delta 5.17$ $(\mathrm{d}, \mathrm{J}=1.0 \mathrm{~Hz}, 1 \mathrm{H}), 5.14(\mathrm{dd}, \mathrm{J}=1.4,1.0 \mathrm{~Hz}, 1 \mathrm{H}), 4.09(\mathrm{dd}, \mathrm{J}=13.9,6.7 \mathrm{~Hz}, 1 \mathrm{H})$, $2.95(\mathrm{~d}, \mathrm{~J}=3.6 \mathrm{~Hz}, 1 \mathrm{H}), 2.61(\mathrm{~d}, \mathrm{~J}=6.3 \mathrm{~Hz}, 1 \mathrm{H}), 2.58-2.52(\mathrm{~m}, 1 \mathrm{H}), 2.41-2.37$ (m, 2H), 2.14-2.08 (m, 1H), 1.93-1.82 (m, 3H), 1.74-1.68 (m, 1H), $1.65(\mathrm{~d}, \mathrm{~J}=$ $12.3 \mathrm{~Hz}, 1 \mathrm{H}), 1.35-1.27(\mathrm{~m}, 1 \mathrm{H}) .{ }^{13} \mathrm{C} \mathrm{NMR}\left(125 \mathrm{MHz}, \mathrm{CDCl}_{3}\right) \delta 211.2,155.4$, 107.2, 79.1, 64.0, 61.0, 45.2, 42.9, 35.7, 35.5, 33.0, 24.7.

\section{Synthetic Procedures Used for Derivatization}

\section{Procedure (i)}

To a stirred solution of carboxylic acid $(1.43 \mathrm{mmol})$ in anhydrous DCM $(2 \mathrm{~mL})$ and one drop of DMF, oxalyl chloride $(2.15 \mathrm{mmol})$ was added dropwise. After stirring for $2 \mathrm{~h}$, the solution was concentrated in vacuo, then re-dissolved in chloroform $(1 \mathrm{~mL})$ and concentrated in vacuo twice to obtain the acid chloride residue. The acid chloride was then dissolved in DCM (1 mL), and added drop-wise to the solution of alcohol 14, $(20$ $\mathrm{mg}, 0.10 \mathrm{mmol})$ in $\mathrm{DCM}(2 \mathrm{~mL})$ and dry triethylamine $(0.16 \mathrm{mmol}, 33 \mu \mathrm{L})$ and a catalytic amount of DMAP $(1 \mathrm{mg})$. The mixture was stirred until complete by TLC (4 
h-24 h). The product was purified by quick silica gel column chromatography and further HPLC where impurities of more than 5\% were present.

\section{Procedure (ii)}

Acetic anhydride (40 $\mu \mathrm{L}, 0.44 \mathrm{mmol})$ was added to a stirred solution of 14 (20 mg, 0.10 mmol), DMAP $(0.5 \mathrm{mg})$, and triethylamine $(21 \mu \mathrm{L}, 0.16 \mathrm{mmol})$. After $20 \mathrm{~h}$, the reaction mixture was quenched by the addition of water $(2 \mathrm{~mL})$, followed by addition of saturated sodium carbonate solution $(2-3 \mathrm{~mL})$. The organic layer extracted with chloroform $(6 \mathrm{~mL})$, dried over anhydrous $\mathrm{MgSO}_{4}$ and the solvent removed to give the crude extract. Silica gel column chromatography on the crude extract gave pure product.

\section{Procedure (iii)}

To stirred $\mathrm{SOCl}_{2}(3.5 \mathrm{~mL})$ was added 1-acetyl-piperidine-4-carboxylic acid (500 mg, $2.92 \mathrm{mmol}$ ) at $\mathrm{rt}$. After $5 \mathrm{~min}$ the acid chloride was precipitated from the solution. The precipitate was collected by vacuum filtration and washed several times with petroleum ether $(150 \mathrm{~mL})$ and filtered to obtain $99 \%$ pure 1-acetyl-piperidine-4-carbonyl chloride as a white powder. The acid chloride (200 $\mathrm{mg}, 896 \mathrm{mmol})$ was the dissolved in anhydrous pyridine $(2 \mathrm{~mL})$, and the resulting solution was added drop-wise to a solution of alcohol 14 (20 mg, $0.10 \mathrm{mmol})$ in pyridine $(3 \mathrm{~mL})$ and DMAP (catalytic amount) under Ar. After $17 \mathrm{~h}$, the mixture was washed with $1 \mathrm{M} \mathrm{HCl}(20 \mathrm{~mL})$ and extracted with ethyl acetate. The organic layer was washed with saturated $\mathrm{NaHCO}_{3}$ solution and dried under $\mathrm{MgSO}_{4}$. The ester product was purified by silica gel column chromatography.

\section{Procedure (iv)}

Alcohol 14 (10 mg, $0.05 \mathrm{mmol})$, carboxylic acid $(0.13 \mathrm{mmol})$ and triphenylphosphine (34 mg, $0.13 \mathrm{mmol}$ ) were added into an oven dried two-necked round bottom flask equipped with condenser (under $\mathrm{N}_{2}$ ) followed by addition of anhydrous toluene ( $1 \mathrm{~mL}$ ). The mixture was stirred for $2-5 \mathrm{~min}$ and then diisopropyl azodicarboxylate $(0.13 \mathrm{mmol}$, 
$17 \mu \mathrm{L})$ was added to it in a drop-wise manner. The reaction mixture was heated to $80{ }^{\circ} \mathrm{C}$ for $2 \mathrm{~h}$ under $\mathrm{N}_{2}$. The crude mixture was concentrated in vacuo and purified by silica gel column chromatography to obtain the pure ester product.

\section{Procedure (v)}

Sodium borohydride $(8 \mathrm{mg}, 0.21 \mathrm{mmol})$ was added at $0{ }^{\circ} \mathrm{C}$ to alcohol $14(20 \mathrm{mg}, 0.10$ mmol) dissolved in dry methanol $(2.5 \mathrm{~mL})$ and the contents was stirred for $1 \mathrm{~h}$ at this temperature. After this, a $2 \mathrm{M}$ aq. $\mathrm{HCl}(0.35 \mathrm{~mL})$ was added to the solution and stirred for 10 min. The solution was neutralized with saturated $\mathrm{NaHCO}_{3}$ solution, and extracted with DCM. The combined organic layer was dried over $\mathrm{MgSO}_{4}$ and concentrated in vacuo. The residue was purified by silica gel column chromatography (hexane/EtOAc/DCM 3:0.5:1) which resulted in two diastereomers.

\section{Procedure (vi)}

Compound 16 (5 mg, $0.014 \mathrm{mmol}$ ) was dissolved in 5\% potassium hydroxide-ethanol solution $(3 \mathrm{~mL})$ and heated to $50{ }^{\circ} \mathrm{C}$ for $3 \mathrm{~h}$ under $\mathrm{N}_{2}$. Following the addition of saturated ammonium chloride solution, the product was extracted with DCM (4 times). The organic layer was dried over $\mathrm{MgSO}_{4}$ and concentrated in vacuo. The crude residue was purified by silica gel column chromatography (hexane/EtOAc 7:3) to obtain compound 17.

\section{Characterization Data for Synthesized Derivatives}

Compound 15a. White powder (87\% yield); m.p. $60-62{ }^{\circ} \mathrm{C} ;{ }^{1} \mathrm{H}$ NMR $(500 \mathrm{MHz}$, $\left.\mathrm{CDCl}_{3}\right) \delta 5.23(\mathrm{~d}, J=1.0 \mathrm{~Hz}, 1 \mathrm{H}), 5.16(\mathrm{dd}, J=1.4,1.0 \mathrm{~Hz}, 1 \mathrm{H}), 4.95(\mathrm{dd}, J=10.7,4.4$ Hz, 1H), $2.94(\mathrm{~d}, J=3.7 \mathrm{~Hz}, 1 \mathrm{H}), 2.78(\mathrm{br} \mathrm{s}, 1 \mathrm{H}), 2.46-2.37(\mathrm{~m}, 3 \mathrm{H}), 2.17-2.10(\mathrm{~m}$, 1H), $2.05(\mathrm{~s}, 3 \mathrm{H}), 1.91-1.86(\mathrm{~m}, 3 \mathrm{H}), 1.81-1.75(\mathrm{~m}, 1 \mathrm{H}), 1.62(\mathrm{~d}, J=12.7 \mathrm{~Hz}, 1 \mathrm{H})$, $1.48-1.43(\mathrm{~m}, 1 \mathrm{H}) ;{ }^{13} \mathrm{C}$ NMR $\left(125 \mathrm{MHz}, \mathrm{CDCl}_{3}\right) \delta 211.0,170.8,154.4,108.7,81.5$, 
64.2, 58.7, 45.2, 41.4, 36.0, 32.6, 31.8, 25.9, 21.4; HRESIMS $\mathrm{m} / \mathrm{z}$ Calcd for $\mathrm{C}_{14} \mathrm{H}_{18} \mathrm{O}_{3} \mathrm{Na}[\mathrm{M}+\mathrm{Na}]^{+}:$257.1148, Found: 257.1149 .

Compound 15b. Colourless oil (70\% yield); ${ }^{1} \mathrm{H}$ NMR $\left(500 \mathrm{MHz}, \mathrm{CDCl}_{3}\right) \delta 5.22(\mathrm{~d}, J=$ $1.0 \mathrm{~Hz}, 1 \mathrm{H}), 5.18(\mathrm{dd}, J=1.4,1.0 \mathrm{~Hz}, 1 \mathrm{H}), 4.97(\mathrm{dd}, J=10.9,4.7 \mathrm{~Hz}, 1 \mathrm{H}), 2.95(\mathrm{~d}, J=$ $3.6 \mathrm{~Hz}, 1 \mathrm{H}), 2.78(\mathrm{~s}, 1 \mathrm{H}), 2.47-2.37(\mathrm{~m}, 3 \mathrm{H}), 2.18(\mathrm{~d}, J=7.4 \mathrm{~Hz}, 2 \mathrm{H}), 2.15-2.08(\mathrm{~m}$, 2H), 1.92-1.86 (m, 3H), 1.78-1.74 (m, 1H), $1.63(\mathrm{~d}, J=12.2 \mathrm{~Hz}, 1 \mathrm{H}), 1.47-1.42(\mathrm{~m}$, 1H), $0.96(\mathrm{~d}, J=6.6 \mathrm{~Hz}, 6 \mathrm{H}) ;{ }^{13} \mathrm{C} \mathrm{NMR}\left(125 \mathrm{MHz}, \mathrm{CDCl}_{3}\right) \delta 211.1,172.9,154.5$, $108.8,81.2,64.2,58.7,45.2,43.8,41.6,36.0,32.6,31.9,25.9$ (2C), 22.6, 22.5; HRESIMS $m / z$ Calcd for $\mathrm{C}_{17} \mathrm{H}_{24} \mathrm{O}_{3} \mathrm{Na}[\mathrm{M}+\mathrm{Na}]^{+}:$299.1618, Found: 299.1620.

Compound 15c'. Colourless oil (56\% yield); ${ }^{1} \mathrm{H}$ NMR $\left(600 \mathrm{MHz}, \mathrm{CDCl}_{3}\right) \delta 5.22(\mathrm{~d}, J=$ $0.9 \mathrm{~Hz}, 1 \mathrm{H}), 5.18(\mathrm{~d}, J=2.2 \mathrm{~Hz}, 1 \mathrm{H}), 4.97$ (dt, $J=6.2,4.7 \mathrm{~Hz}, 1 \mathrm{H}), 4.92(\mathrm{~s}, 1 \mathrm{H}), 4.84$ (s, 1H), $3.01(\mathrm{~s}, 2 \mathrm{H}), 2.94(\mathrm{~d}, J=3.6 \mathrm{~Hz}, 1 \mathrm{H}), 2.78(\mathrm{~s}, 1 \mathrm{H}), 2.43(\mathrm{dt}, J=13.7,8.9 \mathrm{~Hz}$, 1H), 2.40-2.36 (m, 2H), 2.16-2.37 (m, 1H), 1.92-1.84 (m, 3H), 1.80 (s, 3H), 1.79-1.74 $(\mathrm{m}, 1 \mathrm{H}), 1.62(\mathrm{~d}, J=12.4 \mathrm{~Hz}, 1 \mathrm{H}), 1.45(\mathrm{ddd}, J=13.2,7.3,4.6 \mathrm{~Hz}, 1 \mathrm{H}) ;{ }^{13} \mathrm{C} \mathrm{NMR}(150$ $\left.\mathrm{MHz}, \mathrm{CDCl}_{3}\right) \delta 211.0,171.2,154.4,138.5,114.9,108.8,81.7,64.2,58.7,45.2,43.8$, 41.6, 36.0, 32.6, 31.8, 25.9, 22.6; HRESIMS $m / z$ Calcd for $\mathrm{C}_{17} \mathrm{H}_{22} \mathrm{O}_{3} \mathrm{Na}[\mathrm{M}+\mathrm{Na}]^{+}$: 297.1461, Found: 297.1465.

Compound 15d. Mixture of diastereomers, colourless oil (63\% yield); ${ }^{1} \mathrm{H}$ NMR (500 $\left.\mathrm{MHz}, \mathrm{CDCl}_{3}\right) \delta 5.20(\mathrm{~d}, J=1.0 \mathrm{~Hz}, 1 \mathrm{H}), 5.16(\mathrm{dd}, J=1.4,1.0 \mathrm{~Hz}, 1 \mathrm{H}), 4.95(\mathrm{dd}, J=$ 11.1, 4.9 Hz, 1H), 2.96 (d, $J=3.5 \mathrm{~Hz}, 1 \mathrm{H}), 2.76$ (br s, 1H), 2.47-2.31 (m, 4H), 2.19$2.11(\mathrm{~m}, 1 \mathrm{H}), 1.92-1.85(\mathrm{~m}, 3 \mathrm{H}), 1.77-1.70(\mathrm{~m}, 1 \mathrm{H}), 1.69-1.64(\mathrm{~m}, 1 \mathrm{H}), 1.61(\mathrm{~d}, J=$ $12.4 \mathrm{~Hz}, 1 \mathrm{H}), 1.48-1.41(\mathrm{~m}, 2 \mathrm{H}), 1.12(\mathrm{~d}, J=7.0 \mathrm{~Hz}, 3 \mathrm{H}), 0.89(\mathrm{t}, J=7.5 \mathrm{~Hz}, 3 \mathrm{H}) ;{ }^{13} \mathrm{C}$ NMR (125 MHz, $\left.\mathrm{CDCl}_{3}\right) \delta 211.1$ (2C), 176.5 (2C), 154.6, 108.7 (2C), 81.1, 64.2 (2C), 58.7, 45.2, 41.7, 41.6, 41.3 (2C), 36.0 (2C), 32.7 (2C), 32.0 (2C), 26.9 (2C), 25.9 (2C), 
16.7 (2C), 11.8 (2C); HRESIMS $m / z$ Calcd for $\mathrm{C}_{17} \mathrm{H}_{24} \mathrm{O}_{3} \mathrm{Na}[\mathrm{M}+\mathrm{Na}]^{+}: 299.1618$, Found: 299.1622.

Compound 15e. Colourless oil (61\% yield); ${ }^{1} \mathrm{H}$ NMR (500 MHz, $\left.\mathrm{CDCl}_{3}\right) \delta 5.21$ (d, $J=$ $1.0 \mathrm{~Hz}, 1 \mathrm{H}), 5.17(\mathrm{dd}, J=1.4,1.0 \mathrm{~Hz}, 1 \mathrm{H}), 4.95(\mathrm{dd}, J=11.7,5.7 \mathrm{~Hz}, 1 \mathrm{H}), 2.94(\mathrm{~d}, J=$ $3.4 \mathrm{~Hz}, 1 \mathrm{H}), 2.76($ br s, $1 \mathrm{H}), 2.47-2.43(\mathrm{~m}, 1 \mathrm{H}), 2.40-2.37(\mathrm{~m}, 2 \mathrm{H}), 2.36-2.31(\mathrm{~m}, 1 \mathrm{H})$, 2.19-2.12 (m, 1H), 1.92-1.84 (m, 3H), 1.77-1.71 (m, 1H), 1.69-1.65 (m, 1H), $1.62(\mathrm{~d}$, $J=12.8 \mathrm{~Hz}, 1 \mathrm{H}), 1.45-1.37(\mathrm{~m}, 2 \mathrm{H}), 1.13(\mathrm{~d}, J=7.0 \mathrm{~Hz}, 3 \mathrm{H}), 0.89$ (t, $J=7.5 \mathrm{~Hz}, 3 \mathrm{H})$; ${ }^{13} \mathrm{C}$ NMR (125 MHz, $\left.\mathrm{CDCl}_{3}\right) \delta 211.0$ (2C), 176.5 (2C), 154.5, 108.6 (2C), 81.0, 64.2 (2C), 58.7, 45.2, $41.6(2 \mathrm{C}), 41.2$ (2C), 36.0 (2C), 32.6 (2C), 32.0 (2C), 26.9 (2C), 25.8 (2C), 16.6 (2C), 11.7 (2C); HRESIMS $m / z$ Calcd for $\mathrm{C}_{17} \mathrm{H}_{24} \mathrm{O}_{3} \mathrm{Na}[\mathrm{M}+\mathrm{Na}]^{+}:$299.1618, Found: 299.1621.

Compound 15f. Colourless oil (58\% yield); ${ }^{1} \mathrm{H}$ NMR (500 MHz, $\left.\mathrm{CDCl}_{3}\right) \delta 7.35-7.23$ (m, 5H), $5.11(\mathrm{~d}, J=1.9 \mathrm{~Hz}, 1 \mathrm{H}), 5.09(\mathrm{~s}, 1 \mathrm{H}), 4.95(\mathrm{dd}, J=10.7,4.7 \mathrm{~Hz}, 1 \mathrm{H}), 3.60(\mathrm{~s}$, 2H), $2.91(\mathrm{~d}, J=3.7 \mathrm{~Hz}, 1 \mathrm{H}), 2.73(\mathrm{~s}, 1 \mathrm{H}), 2.48-2.31(\mathrm{~m}, 3 \mathrm{H}), 2.20-2.09(\mathrm{~m}, 1 \mathrm{H})$, $1.91-1.82(\mathrm{~m}, 3 \mathrm{H}), 1.81-1.71(\mathrm{~m}, 1 \mathrm{H}), 1.61(\mathrm{~d}, J=12.3 \mathrm{~Hz}, 1 \mathrm{H}), 1.48-1.39(\mathrm{~m}, 1 \mathrm{H})$; ${ }^{13} \mathrm{C}$ NMR $\left(125 \mathrm{MHz}, \mathrm{CDCl}_{3}\right) \delta 211.0,171.4,154.2,134.1,129.3$ (2C), 128.7 (2C), 127.3, 108.8, 81.8, 64.2, 58.6, 45.1, 41.8, 41.5, 36.0, 32.6, 31.8, 25.9; HRESIMS $m / z$ Calcd for $\mathrm{C}_{20} \mathrm{H}_{22} \mathrm{O}_{3} \mathrm{Na}[\mathrm{M}+\mathrm{Na}]^{+}: 333.1461$, Found: 333.1468 .

Compound 15g. Colourless oil (61\% yield); ${ }^{1} \mathrm{H}$ NMR (500 MHz, $\left.\mathrm{CDCl}_{3}\right) \delta 7.28-7.23$ (m, 2H), 7.11-7.04 (m, 2H), $5.14(\mathrm{~d}, J=2.2 \mathrm{~Hz}, 2 \mathrm{H}), 4.97(\mathrm{dd}, J=10.9,4.6 \mathrm{~Hz}, 1 \mathrm{H})$, $3.66(\mathrm{~s}, 2 \mathrm{H}), 2.92(\mathrm{~d}, J=3.6 \mathrm{~Hz}, 1 \mathrm{H}), 2.75(\mathrm{br} \mathrm{s}, 1 \mathrm{H}), 2.44-2.35(\mathrm{~m}, 3 \mathrm{H}), 2.18-2.11(\mathrm{~m}$, 1H) $1.90-1.84(\mathrm{~m}, 3 \mathrm{H}), 1.81-1.75(\mathrm{~m}, 1 \mathrm{H}), 1.61(\mathrm{~d}, J=12.1 \mathrm{~Hz}, 1 \mathrm{H}), 1.46-1.41(\mathrm{~m}$, $1 \mathrm{H}) ;{ }^{13} \mathrm{C} \mathrm{NMR}\left(125 \mathrm{MHz}, \mathrm{CDCl}_{3}\right) \delta 210.9,170.5(\mathrm{~d}, J=1 \mathrm{~Hz}), 161.2(\mathrm{~d}, J=254 \mathrm{~Hz})$, 154.2, $131.5(\mathrm{~d}, J=3 \mathrm{~Hz}), 129.2(\mathrm{~d}, J=8 \mathrm{~Hz}), 124.3(\mathrm{~d}, J=3 \mathrm{~Hz}), 121.5(\mathrm{~d}, J=16 \mathrm{~Hz})$, $115.5(\mathrm{~d}, J=22 \mathrm{~Hz}), 108.8,82.1,64.1,58.6,45.1,41.5,36.0,35.0(\mathrm{~d}, J=3 \mathrm{~Hz}), 32.6$, 
31.7, 25.9; HRESIMS $m / z$ Calcd for $\mathrm{C}_{20} \mathrm{H}_{21} \mathrm{FO}_{3} \mathrm{Na}[\mathrm{M}+\mathrm{Na}]^{+}$: 351.1367, Found: 351.1374 .

Compound 15h. Colourless oil (57\% yield); ${ }^{1} \mathrm{H}$ NMR (500 MHz, $\left.\mathrm{CDCl}_{3}\right) \delta 7.31-7.26$ (m, 1H), 7.06-6.94 (m, 3H), $5.12(\mathrm{~d}, J=2.2 \mathrm{~Hz}, 1 \mathrm{H}), 5.10(\mathrm{~d}, J=1.4 \mathrm{~Hz}, 1 \mathrm{H}), 4.96(\mathrm{dd}$, $J=10.9,4.6 \mathrm{~Hz}, 1 \mathrm{H}), 3.60(\mathrm{~s}, 2 \mathrm{H}), 2.93(\mathrm{~d}, J=3.6 \mathrm{~Hz}, 1 \mathrm{H}), 2.75$ (br s, 1H), 2.47-2.31 $(\mathrm{m}, 3 \mathrm{H}), 2.18-2.11(\mathrm{~m}, 1 \mathrm{H}) 1.90-1.85(\mathrm{~m}, 3 \mathrm{H}), 1.80-1.73(\mathrm{~m}, 1 \mathrm{H}), 1.61(\mathrm{~d}, J=12.4 \mathrm{~Hz}$ 1H), $1.50-1.38(\mathrm{~m}, 1 \mathrm{H}) ;{ }^{13} \mathrm{C}$ NMR $\left(125 \mathrm{MHz}, \mathrm{CDCl}_{3}\right) \delta 210.9,170.8,163.0(\mathrm{~d}, J=248$ $\mathrm{Hz}), 154.2,136.3$ (d, $J=8 \mathrm{~Hz}), 130.1$ (d, $J=9 \mathrm{~Hz}), 125.1$ (d, $J=3 \mathrm{~Hz}), 116.4$ (d, $J=23$ Hz), $114.3(\mathrm{~d}, J=20 \mathrm{~Hz}), 108.8,82.1,68.8,64.2,58.6,45.1,41.5,41.4$ (d, $J=2 \mathrm{~Hz})$, 36.0, 32.6, 31.8, 25.9; HRESIMS $m / z$ Calcd for $\mathrm{C}_{20} \mathrm{H}_{21} \mathrm{FO}_{3} \mathrm{Na}[\mathrm{M}+\mathrm{Na}]^{+}:$351.1367, Found: 351.1380 .

Compound 15i. Colourless oil (42\% yield); ${ }^{1} \mathrm{H}$ NMR $\left(500 \mathrm{MHz}, \mathrm{CDCl}_{3}\right) \delta 5.21(\mathrm{~s}, 1 \mathrm{H})$, $5.18(\mathrm{~d}, J=1.9 \mathrm{~Hz}, 1 \mathrm{H}), 4.96(\mathrm{dd}, J=10.9,4.7 \mathrm{~Hz}, 1 \mathrm{H}), 3.94(\mathrm{dd}, J=11.2,3.7 \mathrm{~Hz}$ 2H), $3.40(\mathrm{t}, J=11.8 \mathrm{~Hz}, 2 \mathrm{H}), 2.95(\mathrm{~d}, J=3.7 \mathrm{~Hz}, 1 \mathrm{H}), 2.76($ br s, $1 \mathrm{H}), 2.46-2.37(\mathrm{~m}$, $3 \mathrm{H}), 2.24(\mathrm{~d}, J=7.1 \mathrm{~Hz}, 2 \mathrm{H}), 2.19-2.12(\mathrm{~m}, 1 \mathrm{H}), 2.05-1.98(\mathrm{~m}, 1 \mathrm{H}), 1.92-1.86(\mathrm{~m}$, $3 \mathrm{H}), 1.79-1.73(\mathrm{~m}, 1 \mathrm{H}), 1.63(\mathrm{~d}, J=12.6 \mathrm{~Hz}, 3 \mathrm{H}), 1.48-1.43(\mathrm{~m}, 1 \mathrm{H}), 1.39-1.30(\mathrm{~m}$, $2 \mathrm{H}) ;{ }^{13} \mathrm{C} \mathrm{NMR}\left(125 \mathrm{MHz}, \mathrm{CDCl}_{3}\right) \delta 211.0,172.2,154.5,108.7,81.4,67.9$ (2C), 64.2, 58.7, 45.2, 41.8, 41.5, 36.0, 32.9, 32.8, 32.6, 32.3, 31.9, 25.9; HRESIMS $m / z$ Calcd for $\mathrm{C}_{19} \mathrm{H}_{26} \mathrm{O} 4 \mathrm{Na}[\mathrm{M}+\mathrm{Na}]^{+}:$341.1723, Found: 341.1727 .

Compound 15j. White powder (56\% yield) m.p. $84-86{ }^{\circ} \mathrm{C} ;{ }^{1} \mathrm{H}$ NMR $(500 \mathrm{MHz}$, $\left.\mathrm{CDCl}_{3}\right) \delta 8.04-8.02(\mathrm{~m}, 2 \mathrm{H}), 7.56(\mathrm{t}, J=7.4 \mathrm{~Hz}, 1 \mathrm{H}), 7.44(\mathrm{t}, J=7.7 \mathrm{~Hz}, 2 \mathrm{H}), 5.32(\mathrm{~s}$, 1H), 5.27-5.16 (m, 2H), $2.98(\mathrm{~d}, J=3.5 \mathrm{~Hz}, 1 \mathrm{H}), 2.95(\mathrm{br} \mathrm{s}, 1 \mathrm{H}), 2.53(\mathrm{dt}, J=13.6,8.9$ $\mathrm{Hz}, 1 \mathrm{H}), 2.42-2.40(\mathrm{~m}, 2 \mathrm{H}), 2.29-2.23(\mathrm{~m}, 1 \mathrm{H}), 1.98-1.86(\mathrm{~m}, 4 \mathrm{H}), 1.66(\mathrm{~d}, J=12.2$ $\mathrm{Hz}, 1 \mathrm{H}), 1.54(\mathrm{ddd}, J=13.3,7.3,4.4 \mathrm{~Hz}, 1 \mathrm{H}) ;{ }^{13} \mathrm{C} \mathrm{NMR}\left(125 \mathrm{MHz}, \mathrm{CDCl}_{3}\right) \delta 211.0$, $166.3,154.4,133.2,130.5,129.7,128.5,109.0,82.1,64.3,58.9,45.2,41.5,36.1,32.6$, 
31.9, 26.1; HRESIMS $\mathrm{m} / z$ Calcd for $\mathrm{C}_{19} \mathrm{H}_{20} \mathrm{O}_{3} \mathrm{Na}[\mathrm{M}+\mathrm{Na}]^{+}$: 319.1305, Found: 319.1312 .

Compound 15k. White powder (56\% yield); m.p. $51-53{ }^{\circ} \mathrm{C} ;{ }^{1} \mathrm{H}$ NMR $(500 \mathrm{MHz}$, $\left.\mathrm{CDCl}_{3}\right) \delta 7.91(\mathrm{td}, J=7.5,1.4 \mathrm{~Hz}, 1 \mathrm{H}), 7.54-7.49(\mathrm{~m}, 1 \mathrm{H}), 7.20(\mathrm{t}, J=7.6 \mathrm{~Hz}, 1 \mathrm{H})$, $7.13(\mathrm{dd}, J=10.7,8.5 \mathrm{~Hz}, 1 \mathrm{H}), 5.35(\mathrm{~s}, 1 \mathrm{H}), 5.22-5.19(\mathrm{~m}, 2 \mathrm{H}), 2.98(\mathrm{~d}, J=3.4 \mathrm{~Hz}$ 1H), 2.95 (br s, 1H), $2.52(\mathrm{dt}, J=13.5,8.8 \mathrm{~Hz}, 1 \mathrm{H}), 2.43-2.37(\mathrm{~m}, 2 \mathrm{H}), 2.31-2.23(\mathrm{~m}$, 1H), $1.98-1.87(\mathrm{~m}, 4 \mathrm{H}), 1.66(\mathrm{~d}, J=12.3 \mathrm{~Hz}, 1 \mathrm{H}), 1.54-1.49(\mathrm{~m}, 1 \mathrm{H}) ;{ }^{13} \mathrm{C}$ NMR $(125$ $\left.\mathrm{MHz}^{\mathrm{CDCl}} \mathrm{CD}_{3}\right) \delta 211.0,164.2(\mathrm{~d}, J=4 \mathrm{~Hz}), 162.2(\mathrm{~d}, J=260 \mathrm{~Hz}), 154.3,134.6(\mathrm{~d}, J=9$ Hz), 132.2, 124.1 (d, $J=4 \mathrm{~Hz}), 119.0(\mathrm{~d}, J=10 \mathrm{~Hz}), 117.2$ (d, $J=22 \mathrm{~Hz}), 109.0,82.4$, 64.2, 58.7, 45.2, 41.6, 36.0, 32.6, 31.9, 26.0; HRESIMS $m / z$ Calcd for $\mathrm{C}_{19} \mathrm{H}_{19} \mathrm{O}{ }_{3} \mathrm{Na}$ $[\mathrm{M}+\mathrm{Na}]^{+}:$337.1210, Found: 337.1221.

Compound 15l. White powder (30\% yield) m.p. $79-81{ }^{\circ} \mathrm{C} ;{ }^{1} \mathrm{H}$ NMR $(500 \mathrm{MHz}$, $\left.\mathrm{CDCl}_{3}\right) \delta$ 7.61-7.57 (m, 1H), 7.24-7.19 (m, 1H), 7.13-7.09 (m, 1H), $5.33(\mathrm{~s}, 1 \mathrm{H}), 5.23$ (d, $J=1.9 \mathrm{~Hz}, 1 \mathrm{H}), 5.20(\mathrm{dd}, J=10.5,4.8 \mathrm{~Hz}, 1 \mathrm{H}), 2.98(\mathrm{~d}, J=3.5 \mathrm{~Hz}, 1 \mathrm{H}), 2.94$ (br s, 1H), $2.52(\mathrm{dt}, J=13.6,8.8 \mathrm{~Hz}, 1 \mathrm{H}), 2.41(\mathrm{dd}, J=8.8,6.0 \mathrm{~Hz}, 2 \mathrm{H}), 2.31-2.24(\mathrm{~m}, 1 \mathrm{H})$, $1.98-1.85(\mathrm{~m}, 4 \mathrm{H}), 1.66(\mathrm{~d}, J=12.2 \mathrm{~Hz}, 1 \mathrm{H}), 1.56-1.50(\mathrm{~m}, 1 \mathrm{H}) ;{ }^{13} \mathrm{C} \mathrm{NMR}(125 \mathrm{MHz}$, $\left.\mathrm{CDCl}_{3}\right) \delta 210.8,163.1(\mathrm{~m}), 158.3(\mathrm{dd}, J=245,3 \mathrm{~Hz}), 157.8(\mathrm{dd}, J=256,2 \mathrm{~Hz}), 154.2$, $121.4(\mathrm{dd}, J=24,9 \mathrm{~Hz}), 120.0(\mathrm{dd}, J=12,8 \mathrm{~Hz}), 118.7(\mathrm{dd}, J=26,8 \mathrm{~Hz}), 118.4(\mathrm{dd}, J$ $=26,1 \mathrm{~Hz}), 109.1,82.9,64.2,58.7,45.2,41.6,36.0,32.6,31.9,26.0$; HRESIMS $m / z$ Calcd for $\mathrm{C}_{19} \mathrm{H}_{18} \mathrm{~F}_{2} \mathrm{O}_{3} \mathrm{Na}[\mathrm{M}+\mathrm{Na}]^{+}$: 355.1116, Found: 355.1121 .

Compound 15m. Colourless crystals (45\% yield). m.p. $131-13{ }^{\circ} \mathrm{C} ;{ }^{1} \mathrm{H}$ NMR $(600$

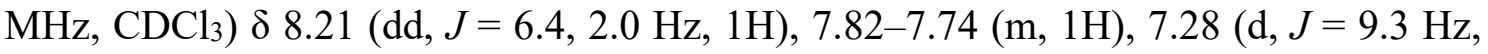
1H), $5.34(\mathrm{~d}, J=1.5 \mathrm{~Hz}, 1 \mathrm{H}), 5.23-5.21(\mathrm{~m}, 2 \mathrm{H}), 2.99(\mathrm{~d}, J=3.6 \mathrm{~Hz}, 1 \mathrm{H}), 2.96(\mathrm{~s}, 1 \mathrm{H})$, $2.53(\mathrm{dt}, J=13.7,8.8 \mathrm{~Hz}, 1 \mathrm{H}), 2.46-2.38(\mathrm{~m}, 2 \mathrm{H}), 2.29(\mathrm{ddt}, J=13.9,9.0,7.1 \mathrm{~Hz}, 1 \mathrm{H})$, 2.00-1.87 (m, 4H), $1.67(\mathrm{~d}, J=12.2 \mathrm{~Hz}, 1 \mathrm{H}), 1.56-1.51(\mathrm{~m}, 1 \mathrm{H}) ;{ }^{13} \mathrm{C} \mathrm{NMR}(125 \mathrm{MHz}$, 
$\left.\mathrm{CDCl}_{3}\right) \delta 210.7,163.4(\mathrm{~d}, J=268 \mathrm{~Hz}), 163.0(\mathrm{~d}, J=4 \mathrm{~Hz}), 154.2,131.6(\mathrm{~m}), 130.0(\mathrm{~m})$, $127.1(\mathrm{~d}, J=34 \mathrm{~Hz}), 123.4$ (q, $J=273 \mathrm{~Hz}), 119.7$ (d, $J=12 \mathrm{~Hz}), 118.2(\mathrm{~d}, J=24 \mathrm{~Hz})$, 109.1, 83.2, 64.3, 58.7, 45.2, 41.6, 36.0, 32.7, 31.9, 26.0; HRESIMS $m / z$ Calcd for $\mathrm{C}_{20} \mathrm{H}_{18} \mathrm{~F}_{4} \mathrm{O}_{3} \mathrm{Na}[\mathrm{M}+\mathrm{Na}]^{+}:$405.1084, Found: 405.1100 .

Compound 15n. White powder (42\% yield); m.p. $43-45{ }^{\circ} \mathrm{C} ;{ }^{1} \mathrm{H}$ NMR $(600 \mathrm{MHz}$, $\left.\mathrm{CDCl}_{3}\right) \delta 8.08(\mathrm{~s}, 1 \mathrm{H}), 7.89(\mathrm{~d}, J=8.5 \mathrm{~Hz}, 1 \mathrm{H}), 7.53(\mathrm{~d}, J=8.0 \mathrm{~Hz}, 1 \mathrm{H}), 5.30(\mathrm{~s}, 1 \mathrm{H})$, $5.24(\mathrm{~s}, 1 \mathrm{H}), 5.23(\mathrm{dd}, J=6.5,4.8 \mathrm{~Hz}, 1 \mathrm{H}), 3.00(\mathrm{~d}, J=3.5 \mathrm{~Hz}, 1 \mathrm{H}), 2.95(\mathrm{~s}, 1 \mathrm{H}), 2.53$ (dt, $J=13.6,8.9 \mathrm{~Hz}, 1 \mathrm{H}), 2.44-2.40(\mathrm{~m}, 2 \mathrm{H}), 2.31-2.25(\mathrm{~m}, 1 \mathrm{H}), 1.99-1.89(\mathrm{~m}, 4 \mathrm{H})$, $1.68(\mathrm{~d}, J=12.2 \mathrm{~Hz}, 1 \mathrm{H}), 1.58-1.37(\mathrm{~m}, 1 \mathrm{H}) ;{ }^{13} \mathrm{C} \mathrm{NMR}\left(150 \mathrm{MHz}, \mathrm{CDCl}_{3}\right) \delta 210.7$, $163.9(\mathrm{~d}, J=3 \mathrm{~Hz}) 162.5(\mathrm{~d}, J=250 \mathrm{~Hz}), 154.2,133.7(\mathrm{~d}, J=7 \mathrm{~Hz}), 133.2(\mathrm{~d}, J=34$ Hz), 122.7 (q, $J=274 \mathrm{~Hz}$, based on HMBC correlations) , 122.4, 120.1 (d, $J=23 \mathrm{~Hz}$ ), , $117.3(\mathrm{~d}, J=24 \mathrm{~Hz}), 109.2,83.3,64.3,58.8,45.2,41.5,36.0,32.6,31.9,26.1$; HRESIMS $m / z$ Calcd for $\mathrm{C}_{20} \mathrm{H}_{18} \mathrm{~F}_{4} \mathrm{O}_{3} \mathrm{Na}[\mathrm{M}+\mathrm{Na}]^{+}:$405.1084, Found: 405.1086 .

Compound 15o. Colourless oil (10\% yield); ${ }^{1} \mathrm{H}$ NMR $\left(500 \mathrm{MHz}, \mathrm{CDCl}_{3}\right) \delta 7.58-7.57$ (m, 1H), 7.17-7.15 (m, 1H), 6.51-6.50 ( m, 1H), $5.30(\mathrm{~s}, 1 \mathrm{H}), 5.21(\mathrm{~d}, J=1.8 \mathrm{~Hz}, 1 \mathrm{H})$, $5.18(\mathrm{dd}, J=10.8,4.9 \mathrm{~Hz}, 1 \mathrm{H}), 2.97(\mathrm{~d}, J=3.5 \mathrm{~Hz}, 1 \mathrm{H}), 2.93($ br s, $1 \mathrm{H}), 2.51(\mathrm{dt}, J=$ 13.6, $8.8 \mathrm{~Hz}, 1 \mathrm{H}), 2.40(\mathrm{dd}, J=9.0,5.9 \mathrm{~Hz}, 2 \mathrm{H}), 2.28-2.21(\mathrm{~m}, 1 \mathrm{H}), 1.97-1.86(\mathrm{~m}, 4 \mathrm{H})$, $1.65(\mathrm{~d}, J=12.1 \mathrm{~Hz}, 1 \mathrm{H}), 1.54-1.48(\mathrm{~m}, 1 \mathrm{H}) ;{ }^{13} \mathrm{C} \mathrm{NMR}\left(125 \mathrm{MHz}, \mathrm{CDCl}_{3}\right) \delta 210.9$, $158.5,154.2,146.5,144.9,118.1,112.0,109.1,82.1,64.3,58.7,45.2,41.6,36.1,32.7$, 31.9, 26.0; HRESIMS $\mathrm{m} / \mathrm{z}$ Calcd for $\mathrm{C}_{17} \mathrm{H}_{18} \mathrm{O}_{4} \mathrm{Na}[\mathrm{M}+\mathrm{Na}]^{+}$: 309.1097, Found: 309.1105 .

Compound 15p. pale pink oil (10\% yield); ${ }^{1} \mathrm{H}$ NMR $\left(500 \mathrm{MHz}, \mathrm{CDCl}_{3}\right) \delta 8.01(\mathrm{~s}, 1 \mathrm{H})$, $7.43(\mathrm{t}, J=1.6 \mathrm{~Hz}, 1 \mathrm{H}), 6.74-6.73(\mathrm{~m}, 1 \mathrm{H}), 5.29(\mathrm{~s}, 1 \mathrm{H}), 5.21(\mathrm{~d}, J=2.2 \mathrm{~Hz}, 1 \mathrm{H}), 5.15$ $(\mathrm{dd}, J=10.7,4.5 \mathrm{~Hz}, 1 \mathrm{H}), 2.97(\mathrm{~d}, J=3.6 \mathrm{~Hz}, 1 \mathrm{H}), 2.89($ br s, $1 \mathrm{H}), 2.48$ (dt, $J=13.7$, $8.9 \mathrm{~Hz}, 1 \mathrm{H}), 2.41(\mathrm{dd}, J=8.8,6.1 \mathrm{~Hz}, 2 \mathrm{H}), 2.22(\mathrm{~m}, 1 \mathrm{H}), 1.97-1.85(\mathrm{~m}, 4 \mathrm{H}), 1.65(\mathrm{~d}, J$ 
$=12.3 \mathrm{~Hz}, 1 \mathrm{H}), 1.55-1.48(\mathrm{~m}, 1 \mathrm{H}) ;{ }^{13} \mathrm{C} \mathrm{NMR}\left(125 \mathrm{MHz}, \mathrm{CDCl}_{3}\right) \delta 211.0,162.9,154.4$, $147.9,143.9,119.7,109.9,108.9,81.6,64.3,58.8,45.2,41.5,36.1,32.6,31.9,26.0$; HRESIMS $m / z$ Calcd for $\mathrm{C}_{17} \mathrm{H}_{18} \mathrm{O}_{4} \mathrm{Na}[\mathrm{M}+\mathrm{Na}]^{+}:$309.1097, Found: 309.1109.

Compound 15q. Mixture of diastereomers, colourless oil (42\% yield); ${ }^{1} \mathrm{H}$ NMR (500 $\left.\mathrm{MHz} \mathrm{CDCl}_{3}\right) \delta 5.21(\mathrm{~d}, J=7.7 \mathrm{~Hz}, 1 \mathrm{H}), 5.18(\mathrm{~s}, 1 \mathrm{H}), 4.96(\mathrm{dd}, J=10.1,4.4 \mathrm{~Hz}, 1 \mathrm{H})$, 4.05-3.93 (m, 1H), 3.81-3.77 (m, 1H), 3.64-3.52 (m, 1H), 3.44-3.39 (m, 1H), $2.95(\mathrm{~d}$, $J=3.5 \mathrm{~Hz}, 1 \mathrm{H}), 2.76(\mathrm{~s}, 1 \mathrm{H}), 2.57(\mathrm{td}, J=9.3,4.4 \mathrm{~Hz}, 1 \mathrm{H}), 2.48-2.37$ (m, 3H), 2.17$2.08(\mathrm{~m}, 1 \mathrm{H}), 2.07-1.98(\mathrm{~m}, 1 \mathrm{H}), 1.89-1.83(\mathrm{~m}, 3 \mathrm{H}), 1.76-1.56(\mathrm{~m}, 5 \mathrm{H}), 1.52-1.41(\mathrm{~m}$, $1 \mathrm{H}) ;{ }^{13} \mathrm{C} \mathrm{NMR}\left(125 \mathrm{MHz}, \mathrm{CDCl}_{3}\right) \delta 210.9,210.8,172.9,172.8,154.4,154.3,108.7$, 81.4 (2C), 69.0 (2C), 68.2, 64.2, 64.1, 58.7, 58.5, 45.1 (2C), 41.8 (2C), 41.6, 41.5, 35.9 (2C), 32.6, 32.5, 31.9, 31.8, 26.0, 25.8 (2C), 24.9, 24.8; HRESIMS $\mathrm{m} / \mathrm{z}$ Calcd for $\mathrm{C}_{18} \mathrm{H}_{24} \mathrm{O}_{4} \mathrm{Na}[\mathrm{M}+\mathrm{Na}]^{+}: 327.1567$, Found: 327.1578 .

Compound 15r. white powder (75\% yield); m.p. $126-127{ }^{\circ} \mathrm{C} ;{ }^{1} \mathrm{H}$ NMR $(400 \mathrm{MHz}$, $\left.\mathrm{CDCl}_{3}\right) \delta 5.19(\mathrm{~s}, 1 \mathrm{H}), 5.18(\mathrm{~s}, 1 \mathrm{H}), 5.02-4.91(\mathrm{~m}, 1 \mathrm{H}), 4.42($ br s, $1 \mathrm{H}), 3.79($ br s, $1 \mathrm{H})$, $3.13($ br s, 1H), $2.95(\mathrm{~d}, J=3.5 \mathrm{~Hz}, 1 \mathrm{H}), 2.81$ (br s, 1H), $2.74(\mathrm{~s}, 1 \mathrm{H}), 2.55-2.48(\mathrm{~m}$, 1H), 2.47-2.34 (m, 3H), 2.19-2.12 (m, 1H), $2.09(\mathrm{~s}, 3 \mathrm{H}), 1.94-1.86(\mathrm{~m}, 6 \mathrm{H}), 1.79-1.71$ (m, 1H), 1.66-1.58 (m, 2H), 1.50-1.41 (m, 1H); ${ }^{13} \mathrm{C}$ NMR (100 MHz, $\left.\mathrm{CDCl}_{3}\right) \delta$ 211.0, $173.9,169.2,154.3,108.8,81.6,64.2,58.7,45.1,41.4,41.1,36.0,32.5,31.9,28.3$, 28.2, 28.1, 28.0, 25.9, 21.5; HRESIMS $m / z$ Calcd for $\mathrm{C}_{20} \mathrm{H}_{27} \mathrm{NO}_{4} \mathrm{Na}[\mathrm{M}+\mathrm{Na}]^{+}$: 368.1832, Found: 368.1826.

Compound 16. white powder (62\% yield); ${ }^{1} \mathrm{H}$ NMR $\left(500 \mathrm{MHz}, \mathrm{CDCl}_{3}\right) \delta 8.28(\mathrm{dd}, J=$ 8.9, $1.3 \mathrm{~Hz}, 2 \mathrm{H}), 8.11(\mathrm{dd}, J=8.9,1.3 \mathrm{~Hz}, 2 \mathrm{H}), 5.77-5.74(\mathrm{~m}, 1 \mathrm{H}), 5.17(\mathrm{~d}, J=1.3 \mathrm{~Hz}$, $1 \mathrm{H}), 4.95(\mathrm{~s}, 1 \mathrm{H}), 3.12(\mathrm{~d}, J=5.4 \mathrm{~Hz}, 1 \mathrm{H}), 3.01(\mathrm{~d}, J=3.3 \mathrm{~Hz}, 1 \mathrm{H}), 2.71-2.66(\mathrm{~m}, 1 \mathrm{H})$, 2.50-2.39 (m, 2H), $2.30(\mathrm{dd}, J=11.9,4.7 \mathrm{~Hz}, 1 \mathrm{H}), 2.18-2.08(\mathrm{~m}, 2 \mathrm{H}), 1.93-1.87(\mathrm{~m}$, 2H), $1.82(\mathrm{~d}, J=12.0 \mathrm{~Hz}, 1 \mathrm{H}), 1.61(\mathrm{dt}, J=13.9,8.7 \mathrm{~Hz}, 1 \mathrm{H}) ;{ }^{13} \mathrm{C}$ NMR $(125 \mathrm{MHz}$, 
$\left.\mathrm{CDCl}_{3}\right) \delta 210.2,164.0,150.8,150.5,135.9,130.5,123.6,109.7,78.4,65.6,58.1,45.9$ $43.8,35.4,34.3,33.3,26.2$.

Compound 17. Colourless oil (69\% yield); ${ }^{1} \mathrm{H} \mathrm{NMR}\left(500 \mathrm{MHz}, \mathrm{CDCl}_{3}\right) \delta 5.36(\mathrm{~d}, J=$ $2.2 \mathrm{~Hz}, 1 \mathrm{H}), 4.99(\mathrm{~d}, J=1.4 \mathrm{~Hz}, 1 \mathrm{H}), 4.26(\mathrm{dd}, J=6.5,2.7 \mathrm{~Hz}, 1 \mathrm{H}), 2.98(\mathrm{~d}, J=3.5 \mathrm{~Hz}$, $1 \mathrm{H}), 2.85(\mathrm{~d}, J=2.2 \mathrm{~Hz}, 1 \mathrm{H}), 2.56(\mathrm{ddd}, J=12.6,9.9,2.5 \mathrm{~Hz}, 1 \mathrm{H}), 2.43-2.32(\mathrm{~m}, 2 \mathrm{H})$, 2.21 (ddd, $J=12.0,4.7,2.8 \mathrm{~Hz}, 1 \mathrm{H}), 2.09-2.04(\mathrm{~m}, 1 \mathrm{H}), 1.95-1.77$ (m, 4H), 1.68 (d, $J$ $=11.9 \mathrm{~Hz}, 1 \mathrm{H}), 1.61-1.55(\mathrm{~m}, 1 \mathrm{H}) ;{ }^{13} \mathrm{C} \mathrm{NMR}\left(125 \mathrm{MHz}, \mathrm{CDCl}_{3}\right) \delta 210.9,153.5,108.8$, 74.5, 65.5, 60.4, 46.7, 44.5, 35.8, 35.5, 33.0, 26.2; HRESIMS $\mathrm{m} / \mathrm{z}$ Calcd for $\mathrm{C}_{12} \mathrm{H}_{16} \mathrm{O}_{2} \mathrm{Na}[\mathrm{M}+\mathrm{Na}]^{+}:$215.1043, Found: 215.1047.

Compound 18a. Colourless oil (85\% yield); ${ }^{1} \mathrm{H} \mathrm{NMR}\left(500 \mathrm{MHz}, \mathrm{CDCl}_{3}\right) \delta 5.49$ (dd, $J$ $=6.0,3.0 \mathrm{~Hz}, 1 \mathrm{H}), 5.20(\mathrm{~s}, 1 \mathrm{H}), 4.91(\mathrm{~s}, 1 \mathrm{H}), 2.96(\mathrm{br} \mathrm{s}, 2 \mathrm{H}), 2.60-2.55(\mathrm{~m}, 1 \mathrm{H}), 2.43-$ $2.35(\mathrm{~m}, 2 \mathrm{H}), 2.21(\mathrm{~d}, J=12.4 \mathrm{~Hz}, 1 \mathrm{H}), 2.00(\mathrm{~s}, 3 \mathrm{H}), 1.99-1.95(\mathrm{~m}, 2 \mathrm{H}), 1.90-1.84(\mathrm{~m}$, 2H), $1.69(\mathrm{~d}, J=11.8 \mathrm{~Hz}, 1 \mathrm{H}), 1.51(\mathrm{dt}, J=13.4,8.7 \mathrm{~Hz}, 1 \mathrm{H}) ;{ }^{13} \mathrm{C}$ NMR $(125 \mathrm{MHz}$, $\left.\mathrm{CDCl}_{3}\right) \delta 210.9,170.4,151.4,109.3,76.6,65.8,58.2,46.1,43.8,35.6,34.3,33.6,26.1$, 21.4; HRESIMS $m / z$ Calcd for $\mathrm{C}_{14} \mathrm{H}_{18} \mathrm{O}_{3} \mathrm{Na}[\mathrm{M}+\mathrm{Na}]^{+}: 257.1148$, Found: 257.1157 .

Compound 18b. Colourless oil (56\% yield); ${ }^{1} \mathrm{H}$ NMR (500 MHz, $\left.\mathrm{CDCl}_{3}\right) \delta 5.58-5.43$ (m, 1H), $5.19(\mathrm{~s}, 1 \mathrm{H}), 4.93(\mathrm{~s}, 1 \mathrm{H}), 2.96(\mathrm{~s}, 2 \mathrm{H}), 2.68-2.52(\mathrm{~m}, 1 \mathrm{H}), 2.45-2.34(\mathrm{~m}, 2 \mathrm{H})$, $2.23(\mathrm{~d}, J=11.8 \mathrm{~Hz}, 1 \mathrm{H}), 2.14(\mathrm{~d}, J=7.2 \mathrm{~Hz}, 2 \mathrm{H}), 2.05(\mathrm{dt}, J=14.1,7.0 \mathrm{~Hz}, 1 \mathrm{H})$, $1.98-1.94(\mathrm{~m}, 2 \mathrm{H}), 1.91-1.84(\mathrm{~m}, 2 \mathrm{H}), 1.70(\mathrm{~d}, J=11.9 \mathrm{~Hz}, 1 \mathrm{H}), 1.49(\mathrm{dt}, J=13.5,9.0$ $\mathrm{Hz}, 1 \mathrm{H}), 0.94(\mathrm{~d}, J=6.6 \mathrm{~Hz}, 6 \mathrm{H}) ;{ }^{13} \mathrm{C} \mathrm{NMR}\left(100 \mathrm{MHz}, \mathrm{CDCl}_{3}\right) \delta 211.0,172.4,151.2$, $109.4,76.6,65.7,58.3,46.1,44.1,44.0,35.6,34.7,33.6,26.2,25.8,22.6,22.5$; HRESIMS $m / z$ Calcd for $\mathrm{C}_{17} \mathrm{H}_{25} \mathrm{O}_{3} \mathrm{Na}[\mathrm{M}+\mathrm{H}]^{+}:$277.1798, Found: 277.1805 .

Compound 18d. Mixture of diastereomers, colourless oil (68\% yield); ${ }^{1} \mathrm{H}$ NMR (500 $\left.\mathrm{MHz}, \mathrm{CDCl}_{3}\right) \delta 5.50-5.48(\mathrm{~m}, 1 \mathrm{H}), 5.18(\mathrm{~d}, J=2.3 \mathrm{~Hz}, 1 \mathrm{H}), 4.93(\mathrm{ddd}, J=4.2,1.8,0.7$ $\mathrm{Hz}, 1 \mathrm{H}), 2.96$ (br s, 2H), 2.67-2.56 (m, 1H), 2.46-2.32 (m, 2H), 2.34-2.27 (m, 1H), 
$2.24(\mathrm{ddd}, J=11.9,4.5,2.5 \mathrm{~Hz}, 1 \mathrm{H}), 1.98-1.94(\mathrm{~m}, 2 \mathrm{H}), 1.90-1.85(\mathrm{~m}, 2 \mathrm{H}), 1.71(\mathrm{~d}, J$ $=11.7 \mathrm{~Hz}, 1 \mathrm{H}), 1.67-1.59(\mathrm{~m}, 1 \mathrm{H}), 1.53-1.38(\mathrm{~m}, 2 \mathrm{H}), 1.10(\mathrm{~d}, J=7.0,3 \mathrm{H}), 0.89(\mathrm{t}, J=$ 7.4, 3H); ${ }^{13} \mathrm{C} \mathrm{NMR}\left(125 \mathrm{MHz}, \mathrm{CDCl}_{3}\right) \delta 211.0,175.9,151.0,109.4$ (2C), 76.4, 76.3, 65.7, $58.4(2 \mathrm{C}), 46.2(2 \mathrm{C}), 44.0(2 \mathrm{C}), 41.7,41.6,35.6,34.7,33.6,26.8$ (2C), 26.3, 17.0, 16.8, 11.8, 11.7; HRESIMS $m / z$ Calcd for $\mathrm{C}_{17} \mathrm{H}_{24} \mathrm{O}_{3} \mathrm{Na}[\mathrm{M}+\mathrm{Na}]^{+}:$299.1618, Found: 299.1634.

Compound 18f. white powder (72\% yield); m.p. 54-56 ${ }^{\circ} \mathrm{C} ;{ }^{1} \mathrm{H}$ NMR (500 MHz, $\left.\mathrm{CDCl}_{3}\right) \delta 7.40-7.15(\mathrm{~m}, 5 \mathrm{H}), 5.58-5.42(\mathrm{~m}, 1 \mathrm{H}), 5.00(\mathrm{~d}, J=2.2 \mathrm{~Hz}, 1 \mathrm{H}), 4.83(\mathrm{~d}, J=$ $1.2 \mathrm{~Hz}, 1 \mathrm{H}), 3.52(\mathrm{~d}, J=15.0 \mathrm{~Hz}, 1 \mathrm{H}), 3.48(\mathrm{~d}, J=15.0 \mathrm{~Hz}, 1 \mathrm{H}), 2.90(\mathrm{~d}, J=5.5 \mathrm{~Hz}$, 1H), $2.68(\mathrm{~d}, J=3.7 \mathrm{~Hz}, 1 \mathrm{H}), 2.58-2.53(\mathrm{~m}, 1 \mathrm{H}), 2.35-2.32(\mathrm{~m}, 2 \mathrm{H}), 1.95-1.91(\mathrm{~m}$, $2 \mathrm{H}), 1.87-1.77(\mathrm{~m}, 3 \mathrm{H}), 1.51(\mathrm{~d}, J=11.8 \mathrm{~Hz}, 1 \mathrm{H}), 1.37(\mathrm{dt}, J=13.6,9.1 \mathrm{~Hz}, 1 \mathrm{H}) ;{ }^{13} \mathrm{C}$ NMR (125 MHz, $\left.\mathrm{CDCl}_{3}\right) \delta 210.9,170.7,150.8,134.2,129.6$ (2C), $128.6(2 \mathrm{C}), 127.1$, 109.4, 77.1, 65.6, 58.3, 46.0, 43.7, 42.1, 35.6, 34.5, 33.5, 26.1; HRESIMS $m / z$ Calcd for $\mathrm{C}_{20} \mathrm{H}_{22} \mathrm{O}_{3} \mathrm{Na}[\mathrm{M}+\mathrm{Na}]^{+}:$333.1461, Found: 333.1455.

Compound 18g. white powder (68\% yield); m.p. 54-56 ${ }^{\circ} \mathrm{C} ;{ }^{1} \mathrm{H}$ NMR $(500 \mathrm{MHz}$, $\left.\mathrm{CDCl}_{3}\right) \delta 7.27-7.17(\mathrm{~m}, 2 \mathrm{H}), 7.08(\mathrm{td}, J=7.5,1.2 \mathrm{~Hz}, 1 \mathrm{H}), 7.03(\mathrm{ddd}, J=9.5,8.2,1.0$ $\mathrm{Hz}, 1 \mathrm{H}), 5.48$ (ddd, $J=5.7,4.2,1.8 \mathrm{~Hz}, 1 \mathrm{H}), 5.03$ (d, $J=2.2 \mathrm{~Hz}, 1 \mathrm{H}), 4.83$ (d, $J=1.2$ $\mathrm{Hz}, 1 \mathrm{H}), 3.64(\mathrm{~d}, J=15.9 \mathrm{~Hz}, 1 \mathrm{H}), 3.59(\mathrm{~d}, J=15.9 \mathrm{~Hz}, 1 \mathrm{H}), 2.89(\mathrm{~d}, J=5.5 \mathrm{~Hz}, 1 \mathrm{H})$, $2.66(\mathrm{~d}, J=3.8 \mathrm{~Hz}, 1 \mathrm{H}), 2.61-2.46(\mathrm{~m}, 1 \mathrm{H}), 2.37-2.26(\mathrm{~m}, 2 \mathrm{H}), 1.99-1.87(\mathrm{~m}, 2 \mathrm{H})$, $1.84-1.67(\mathrm{~m}, 3 \mathrm{H}), 1.47(\mathrm{~d}, J=11.8 \mathrm{~Hz}, 1 \mathrm{H}), 1.40-1.30(\mathrm{~m}, 1 \mathrm{H}) ;{ }^{13} \mathrm{C} \mathrm{NMR}(125 \mathrm{MHz}$, $\left.\mathrm{CDCl}_{3}\right) \delta 210.9,169.8,162.2(\mathrm{~d}, J=247 \mathrm{~Hz}), 150.7,131.7(\mathrm{~d}, J=4 \mathrm{~Hz}), 129.1(\mathrm{~d}, J=8$ Hz), 124.1 (d, $J=4 \mathrm{~Hz}), 121.7$ (d, $J=16 \mathrm{~Hz}), 115.5$ (d, $J=22 \mathrm{~Hz}), 109.3,77.4,65.5$, 58.3, 46.0, 43.6, 35.5, 35.2, 34.5, 33.5, 26.1; HRESIMS $m / z$ Calcd for $\mathrm{C}_{20} \mathrm{H}_{21} \mathrm{FO}_{3} \mathrm{Na}$ $[\mathrm{M}+\mathrm{Na}]^{+}:$351.1367, Found: 351.1375. 
Compound 18h. Colourless oil (75\% yield); ${ }^{1} \mathrm{H}$ NMR (500 MHz, $\left.\mathrm{CDCl}_{3}\right) \delta 7.33-7.20$ (m, 1H), 7.05-6.86 (m, 3H), 5.49-5.47 (m, 1H), $5.01(\mathrm{~d}, J=2.1 \mathrm{~Hz}, 1 \mathrm{H}), 4.82(\mathrm{~s}, 1 \mathrm{H})$, $3.57(\mathrm{~d}, J=15.1 \mathrm{~Hz}, 1 \mathrm{H}), 3.53(\mathrm{~d}, J=15.1 \mathrm{~Hz}, 1 \mathrm{H}), 2.90(\mathrm{~d}, J=5.4 \mathrm{~Hz}, 1 \mathrm{H}), 2.70(\mathrm{~d}, J$ $=3.7 \mathrm{~Hz}, 1 \mathrm{H}), 2.62-2.45(\mathrm{~m}, 1 \mathrm{H}), 2.34-2.31(\mathrm{~m}, 2 \mathrm{H}), 2.02-1.88(\mathrm{~m}, 2 \mathrm{H}), 1.87-1.73(\mathrm{~m}$, $3 \mathrm{H}), 1.53(\mathrm{~d}, J=12.0 \mathrm{~Hz}, 1 \mathrm{H}), 1.36(\mathrm{dt}, J=13.6,9.1 \mathrm{~Hz}, 1 \mathrm{H}) ;{ }^{13} \mathrm{C} \mathrm{NMR}(125 \mathrm{MHz}$, $\left.\mathrm{CDCl}_{3}\right) \delta 210.8,170.1,162.9(\mathrm{~d}, J=246 \mathrm{~Hz}), 150.8,136.5(\mathrm{~d}, J=8 \mathrm{~Hz}), 130.0(\mathrm{~d}, J=8$ Hz), $125.3(\mathrm{~d}, J=3 \mathrm{~Hz}), 116.6(\mathrm{~d}, J=22 \mathrm{~Hz}), 114.1$ (d, $J=21 \mathrm{~Hz}), 109.4,77.4,65.6$, 58.3, 46.0, 43.7, 41.8, 35.5, 34.5, 33.5, 26.1; HRESIMS m/z Calcd for $\mathrm{C}_{20} \mathrm{H}_{21} \mathrm{FO}_{3} \mathrm{Na}$ $[\mathrm{M}+\mathrm{Na}]^{+}:$351.1367, Found: 351.1360.

Compound 18i. white powder (69\% yield); m.p. $98-101{ }^{\circ} \mathrm{C} ;{ }^{1} \mathrm{H}$ NMR (500 MHz, $\left.\mathrm{CDCl}_{3}\right) \delta 5.51(\mathrm{dt}, J=5.9,3.1 \mathrm{~Hz}, 1 \mathrm{H}), 5.17(\mathrm{~d}, J=2.2 \mathrm{~Hz}, 1 \mathrm{H}), 4.91(\mathrm{~d}, J=1.0 \mathrm{~Hz}$, 1H), $3.94(\mathrm{~d}, J=11.9 \mathrm{~Hz}, 1 \mathrm{H}), 3.93(\mathrm{~d}, J=11.9 \mathrm{~Hz}, 1 \mathrm{H}), 3.38(\mathrm{tdd}, J=11.8,5.5,2.1$ $\mathrm{Hz}, 2 \mathrm{H}), 2.95(\mathrm{t}, J=5.3 \mathrm{~Hz}, 2 \mathrm{H}), 2.68-2.55(\mathrm{~m}, 1 \mathrm{H}), 2.44-2.34(\mathrm{~m}, 2 \mathrm{H}), 2.26-2.15(\mathrm{~m}$, $3 \mathrm{H}), 2.01-1.92(\mathrm{~m}, 3 \mathrm{H}), 1.92-1.82(\mathrm{~m}, 2 \mathrm{H}), 1.71(\mathrm{~d}, J=11.8 \mathrm{~Hz}, 1 \mathrm{H}), 1.66-1.60(\mathrm{~m}$, 2H), $1.52-1.45(\mathrm{~m}, 1 \mathrm{H}), 1.37-1.22(\mathrm{~m}, 2 \mathrm{H}) ;{ }^{13} \mathrm{C} \mathrm{NMR}\left(125 \mathrm{MHz}, \mathrm{CDCl}_{3}\right) \delta 210.8$, 171.6, 151.3, 109.4, 76.8, 67.9 (2C), 65.7, 58.3, 46.1, 43.9, 42.0, 35.6, 34.6, 33.5, 32.8, 32.8, 32.2, 26.2; HRESIMS $m / z$ Calcd for $\mathrm{C}_{19} \mathrm{H}_{26} \mathrm{O}_{4} \mathrm{Na}[\mathrm{M}+\mathrm{Na}]^{+}:$341.1723, Found: 341.1717 .

Compound 18j. white powder (68\% yield); m.p. $58-61{ }^{\circ} \mathrm{C} ;{ }^{1} \mathrm{H}$ NMR $(500 \mathrm{MHz}$, $\left.\mathrm{CDCl}_{3}\right) \delta$ 7.97-7.94 (m, 2H), 7.57-7.54 (m, 1H), 7.45-7.42 (m, 2H), $5.73(\mathrm{ddd}, J=6.1$, 4.4, $2.0 \mathrm{~Hz}, 1 \mathrm{H}), 5.17(\mathrm{~d}, J=2.2 \mathrm{~Hz}, 1 \mathrm{H}), 4.97(\mathrm{~d}, J=1.3 \mathrm{~Hz}, 1 \mathrm{H}), 3.09(\mathrm{~d}, J=5.7 \mathrm{~Hz}$, 1H), $3.02(\mathrm{~d}, J=3.7 \mathrm{~Hz}, 1 \mathrm{H}), 2.67(\mathrm{ddd}, J=13.4,9.3,3.7 \mathrm{~Hz}, 1 \mathrm{H}), 2.51-2.31(\mathrm{~m}, 3 \mathrm{H})$, 2.19-2.03 (m, 2H), 1.92-1.89 (m, 2H), $1.80(\mathrm{~d}, J=11.9 \mathrm{~Hz}, 1 \mathrm{H}), 1.67-1.54(\mathrm{~m}, 1 \mathrm{H})$; ${ }^{13} \mathrm{C}$ NMR $\left(125 \mathrm{MHz}, \mathrm{CDCl}_{3}\right) \delta 211.0,166.0,150.9,133.0,130.7,129.6,128.5,109.7$, 
77.5, 65.8, 58.4, 46.1, 44.1, 35.6, 34.6, 33.5, 26.3; HRESIMS $\mathrm{m} / \mathrm{z}$ Calcd for $\mathrm{C}_{19} \mathrm{H}_{20} \mathrm{O}_{3} \mathrm{Na}[\mathrm{M}+\mathrm{Na}]^{+}:$319.1305, Found: 319.1307.

Compound 18k. white powder (76\% yield); m.p. $78-79{ }^{\circ} \mathrm{C} ;{ }^{1} \mathrm{H}$ NMR $(500 \mathrm{MHz}$, $\left.\mathrm{CDCl}_{3}\right) \delta 7.87(\mathrm{td}, J=7.6,1.8 \mathrm{~Hz}, 1 \mathrm{H}), 7.53-7.49(\mathrm{~m}, 1 \mathrm{H}), 7.20(\mathrm{t}, J=7.6 \mathrm{~Hz}, 1 \mathrm{H})$, $7.11(\mathrm{dd}, J=10.8,8.4 \mathrm{~Hz}, 1 \mathrm{H}), 5.77(\mathrm{t}, J=4.3 \mathrm{~Hz}, 1 \mathrm{H}), 5.18(\mathrm{~d}, J=1.9 \mathrm{~Hz}, 1 \mathrm{H}), 4.98$ (s, 1H), $3.08(\mathrm{~d}, J=5.6 \mathrm{~Hz}, 1 \mathrm{H}), 2.99($ br s, $1 \mathrm{H}), 2.66(\mathrm{ddd}, J=13.3,9.6,3.4 \mathrm{~Hz}, 1 \mathrm{H})$, 2.43-2.38 (m, 3H), 2.17-2.04 (m, 2H), 1.95-1.85 (m, 2H), $1.72(1 \mathrm{H}, \mathrm{d}, J=11.9 \mathrm{~Hz}$, 1H), $1.64-1.57(\mathrm{~m}, 1 \mathrm{H}) ;{ }^{13} \mathrm{C}$ NMR $\left(125 \mathrm{MHz}, \mathrm{CDCl}_{3}\right) \delta 211.0,163.9(\mathrm{~d}, J=3 \mathrm{~Hz})$, $162.0(\mathrm{~d}, J=260 \mathrm{~Hz}), 151.2,134.5(\mathrm{~d}, J=9 \mathrm{~Hz}), 132.2,124.1(\mathrm{~d}, J=4 \mathrm{~Hz}), 119.2$, $117.1(\mathrm{~d}, J=23 \mathrm{~Hz}), 109.5,77.9,65.8,58.5,46.15,43.6,35.6,34.7,33.6,26.3$; HRESIMS $m / z$ Calcd for $\mathrm{C}_{19} \mathrm{H}_{19} \mathrm{FO}_{3} \mathrm{Na}[\mathrm{M}+\mathrm{Na}]^{+}: 337.1210$, Found: 337.1219 .

Compound 18I. white powder (39\% yield); m.p. $83-86{ }^{\circ} \mathrm{C} ;{ }^{1} \mathrm{H}$ NMR $(600 \mathrm{MHz}$, $\left.\mathrm{CDCl}_{3}\right) \delta 7.54(\mathrm{ddd}, J=8.7,5.5,3.3 \mathrm{~Hz}, 1 \mathrm{H}), 7.20(\mathrm{dtd}, J=10.6,7.1,3.3 \mathrm{~Hz}, 1 \mathrm{H}), 7.09$ (td, $J=9.4,4.2 \mathrm{~Hz}, 1 \mathrm{H}), 5.75(\mathrm{dd}, J=7.2,3.0 \mathrm{~Hz}, 1 \mathrm{H}), 5.19(\mathrm{~d}, J=2.0 \mathrm{~Hz}, 1 \mathrm{H}), 4.97$ (s, 1H), $3.08(\mathrm{~d}, J=5.5 \mathrm{~Hz}, 1 \mathrm{H}), 3.00(\mathrm{~d}, J=3.3 \mathrm{~Hz}, 1 \mathrm{H}), 2.66(\mathrm{ddd}, J=13.4,9.5,3.6$ $\mathrm{Hz}, 1 \mathrm{H}), 2.47-2.40(\mathrm{~m}, 2 \mathrm{H}), 2.37$ (ddd, $J=12.1,4.8,2.3 \mathrm{~Hz}, 1 \mathrm{H}), 2.17-2.06(\mathrm{~m}, 2 \mathrm{H})$, $1.93-1.86(\mathrm{~m}, 2 \mathrm{H}), 1.73(\mathrm{~d}, J=11.9 \mathrm{~Hz}, 1 \mathrm{H}), 1.63-1.56(\mathrm{~m}, 1 \mathrm{H}) ;{ }^{13} \mathrm{C} \mathrm{NMR}(150 \mathrm{MHz}$, $\left.\mathrm{CDCl}_{3}\right) \delta 210.8,163.1(\mathrm{~m}), 158.3(\mathrm{dd}, J=245,3 \mathrm{~Hz}), 157.8(\mathrm{dd}, J=256,2 \mathrm{~Hz}), 121.2$ $(\mathrm{dd}, J=24,9 \mathrm{~Hz}), 120.2(\mathrm{dd}, J=13,8 \mathrm{~Hz}), 118.5(\mathrm{dd}, J=26,8 \mathrm{~Hz}), 118.2(\mathrm{dd}, J=26$, $2 \mathrm{~Hz}), 109.6$, 78.4, 65.8, 58.4, 46.1, 43.6, 35.6, 34.6, 33.6, 26.3; HRESIMS m/z Calcd for $\mathrm{C}_{19} \mathrm{H}_{18} \mathrm{~F}_{2} \mathrm{O}_{3} \mathrm{Na}[\mathrm{M}+\mathrm{Na}]^{+}:$355.1116, Found: 355.1115 .

Compound 18m. White powder (51\% yield); m.p. $75-77{ }^{\circ} \mathrm{C} ;{ }^{1} \mathrm{H}$ NMR $(500 \mathrm{MHz}$, $\left.\mathrm{CDCl}_{3}\right) \delta 8.26-8.11(\mathrm{dd}, J=6.5,2.3 \mathrm{~Hz}, 1 \mathrm{H}), 7.78(\mathrm{~m}, 1 \mathrm{H}), 7.26(\mathrm{~m}, 1 \mathrm{H}), 5.77(\mathrm{ddd}, J=$ 6.1, 4.3, 2.0 Hz, 1H), 5.27-5.12 (m, 1H), 4.97 (dd, $J=1.9,0.8 \mathrm{~Hz}, 1 \mathrm{H}), 3.10(\mathrm{~d}, J=5.8$ $\mathrm{Hz}, 1 \mathrm{H}), 3.00(\mathrm{~d}, J=4.1 \mathrm{~Hz}, 1 \mathrm{H}), 2.67(\mathrm{ddd}, J=13.4,9.3,3.9 \mathrm{~Hz}, 1 \mathrm{H}), 2.52-2.37(\mathrm{~m}$, 
2H), $2.36(\mathrm{ddd}, J=12.1,4.9,2.3 \mathrm{~Hz}, 1 \mathrm{H}), 2.21-2.02(\mathrm{~m}, 2 \mathrm{H}), 1.98-1.83(\mathrm{~m}, 2 \mathrm{H}), 1.74$ $(\mathrm{dt}, J=12.1,1.0 \mathrm{~Hz}, 1 \mathrm{H}), 1.69-1.49(\mathrm{~m}, 1 \mathrm{H}) ;{ }^{13} \mathrm{C} \mathrm{NMR}\left(125 \mathrm{MHz}, \mathrm{CDCl}_{3}\right) \delta 210.8$. $163.5(\mathrm{~d}, J=265 \mathrm{~Hz}), 162.6(\mathrm{~d}, J=4 \mathrm{~Hz}), 151.2,131.6(\mathrm{~m}), 130.2(\mathrm{~m}), 127.2(\mathrm{dd}, J=$ 32, $4 \mathrm{~Hz}), 124.5(\mathrm{q}, J=272 \mathrm{~Hz}), 120.0(\mathrm{~d}, J=10 \mathrm{~Hz}), 118.2(\mathrm{~d}, J=23 \mathrm{~Hz}), 109.6$, 78.7, 65.7, 58.4, 46.0, 43.6, 35.6, 34.6, 33.6, 26.2; HRESIMS $\mathrm{m} / \mathrm{z}$ Calcd for $\mathrm{C}_{20} \mathrm{H}_{18} \mathrm{~F}_{4} \mathrm{O}_{3} \mathrm{Na}[\mathrm{M}+\mathrm{Na}]^{+}:$405.1084, Found: 405.1092.

Compound 18n. White powder (54\% yield); m.p. $74-76{ }^{\circ} \mathrm{C} ;{ }^{1} \mathrm{H}$ NMR $(500 \mathrm{MHz}$, $\left.\mathrm{CDCl}_{3}\right) \delta 8.18(\mathrm{~d}, J=4.2 \mathrm{~Hz}, 1 \mathrm{H}), 7.88-7.66(\mathrm{~m}, 1 \mathrm{H}), 7.38-7.15(\mathrm{~m}, 1 \mathrm{H}), 5.77(\mathrm{~d}, J=$ $3.9 \mathrm{~Hz}, 1 \mathrm{H}), 5.20(\mathrm{~d}, J=1.7 \mathrm{~Hz}, 1 \mathrm{H}), 4.97(\mathrm{~s}, 1 \mathrm{H}), 3.10(\mathrm{~d}, J=5.0 \mathrm{~Hz}, 1 \mathrm{H}), 3.00(\mathrm{~d}, J=$ $2.5 \mathrm{~Hz}, 1 \mathrm{H}), 2.67$ (ddd, $J=13.3,9.3,3.6 \mathrm{~Hz}, 1 \mathrm{H}), 2.45-2.41(\mathrm{~m}, 2 \mathrm{H}), 2.36(\mathrm{dd}, J=$ 12.1, $2.4 \mathrm{~Hz}, 1 \mathrm{H}), 2.20-2.05(\mathrm{~m}, 2 \mathrm{H}), 1.90(\mathrm{t}, J=6.7 \mathrm{~Hz}, 2 \mathrm{H}), 1.75(\mathrm{~d}, J=12.1 \mathrm{~Hz}$, 1H), $1.66-1.50(\mathrm{~m}, 1 \mathrm{H}) ;{ }^{13} \mathrm{C} \mathrm{NMR}\left(125 \mathrm{MHz}, \mathrm{CDCl}_{3}\right) \delta 211.3,163.1(\mathrm{~d}, J=266 \mathrm{~Hz})$, $162.7(\mathrm{~d}, J=4 \mathrm{~Hz}), 151.1,131.5(\mathrm{~m}), 130.1(\mathrm{~m}), 127.1(\mathrm{dd}, J=34,4 \mathrm{~Hz}), 123.4(\mathrm{q}, J=$ $273 \mathrm{~Hz}), 119.9(\mathrm{~d}, J=11 \mathrm{~Hz}), 118.1(\mathrm{~d}, J=24 \mathrm{~Hz}), 109.6,78.7,65.7,58.4,46.0,43.6$, 35.6, 34.6, 33.6, 26.2; HRESIMS $m / z$ Calcd for $\mathrm{C}_{20} \mathrm{H}_{18} \mathrm{~F}_{4} \mathrm{O}_{3} \mathrm{Na}[\mathrm{M}+\mathrm{Na}]^{+}$: 405.1084, Found: 405.1105.

Compound 180. White powder (12\% yield); m.p. $127-130{ }^{\circ} \mathrm{C} ;{ }^{1} \mathrm{H}$ NMR $(600 \mathrm{MHz}$, $\left.\mathrm{CDCl}_{3}\right) \delta 7.93(\mathrm{~d}, J=1.7 \mathrm{~Hz}, 1 \mathrm{H}), 7.42(\mathrm{t}, J=1.4 \mathrm{~Hz}, 1 \mathrm{H}), 6.68(\mathrm{~d}, J=1.4 \mathrm{~Hz}, 1 \mathrm{H})$, 5.74-5.55 (m, 1H), $5.18(\mathrm{~d}, J=1.9 \mathrm{~Hz}, 1 \mathrm{H}), 4.96(\mathrm{~s}, 1 \mathrm{H}), 3.04(\mathrm{~d}, J=5.5 \mathrm{~Hz}, 1 \mathrm{H}), 2.99$ $(\mathrm{d}, J=3.4 \mathrm{~Hz}, 1 \mathrm{H}), 2.65(\mathrm{ddd}, J=13.4,9.4,3.6 \mathrm{~Hz}, 1 \mathrm{H}), 2.48-2.36(\mathrm{~m}, 2 \mathrm{H}), 2.28$ (ddd, $J=11.9,4.7,2.5 \mathrm{~Hz}, 1 \mathrm{H}), 2.14-1.99(\mathrm{~m}, 2 \mathrm{H}), 1.94-1.84(\mathrm{~m}, 2 \mathrm{H}), 1.77$ (d, $J=11.9 \mathrm{~Hz}$, $1 \mathrm{H}), 1.56(\mathrm{dt}, J=13.8,8.7 \mathrm{~Hz}, 1 \mathrm{H}) ;{ }^{13} \mathrm{C} \mathrm{NMR}\left(150 \mathrm{MHz}, \mathrm{CDCl}_{3}\right) \delta 210.7,162.4,151.0$, $147.5,143.9,119.9,109.9,109.6,77.3,65.7,58.3,46.1,44.0,35.6,34.5,33.5,26.3$; HRESIMS $m / z$ Calcd for $\mathrm{C}_{17} \mathrm{H}_{18} \mathrm{O}_{4} \mathrm{Na}[\mathrm{M}+\mathrm{Na}]^{+}:$309.1097, Found: 309.1102 . 
Compound 18p. Colourless oil (12\% yield); ${ }^{1} \mathrm{H}$ NMR $\left(600 \mathrm{MHz}, \mathrm{CDCl}_{3}\right) \delta 7.63$ (s, 1H), $7.31(\mathrm{~d}, J=3.5 \mathrm{~Hz}, 1 \mathrm{H}), 6.55(\mathrm{dd}, J=3.4,1.6 \mathrm{~Hz}, 1 \mathrm{H}), 5.38(\mathrm{~d}, J=2.0 \mathrm{~Hz}, 1 \mathrm{H})$, $5.01(\mathrm{~s}, 1 \mathrm{H}), 4.29(\mathrm{t}, J=4.5 \mathrm{~Hz}, 1 \mathrm{H}), 3.00(\mathrm{~d}, J=3.5 \mathrm{~Hz}, 1 \mathrm{H}), 2.88(\mathrm{~d}, J=2.4 \mathrm{~Hz}, 1 \mathrm{H})$, 2.63-2.53 (m, 1H), 2.47-2.34 (m, 2H), 2.23 (ddd, $J=11.9,4.5,2.9 \mathrm{~Hz}, 1 \mathrm{H}), 2.11-1.98$ (m, 1H), 1.97-1.79 (m, 3H), $1.71(\mathrm{~d}, J=11.9 \mathrm{~Hz}, 1 \mathrm{H}), 1.58(\mathrm{ddd}, J=13.5,9.9,8.1 \mathrm{~Hz}$ $1 \mathrm{H}) ;{ }^{13} \mathrm{C} \mathrm{NMR}\left(150 \mathrm{MHz}, \mathrm{CDCl}_{3}\right) \delta 211.1,162.4,153.5,147.3,144.1,119.9,112.3$, 108.9, 74.6, 65.6, 60.5, 46.7, 44.5, 35.8, 35.6, 33.0, 26.2; HRESIMS $m / z$ Calcd for $\mathrm{C}_{17} \mathrm{H}_{18} \mathrm{O}_{4} \mathrm{Na}[\mathrm{M}+\mathrm{Na}]^{+}:$309.1097, Found: 309.1102.

Compound 18q. Mixture of diastereomers, colourless oil (42\% yield); ${ }^{1} \mathrm{H}$ NMR (500 $\left.\mathrm{MHz}, \mathrm{CDCl}_{3}\right) \delta 5.51(\mathrm{ddd}, J=6.0,4.0,2.3 \mathrm{~Hz}, 1 \mathrm{H}), 5.20-5.19(\mathrm{~m}, 1 \mathrm{H}), 4.90(\mathrm{~d}, J=1.1$ Hz, 1H), 3.99 (ddd, $J=11.3,4.2,1.6 \mathrm{~Hz}, 1 \mathrm{H}), 3.84$ (dd, $J=11.7,3.3 \mathrm{~Hz}, 1 \mathrm{H}), 3.54-$ $3.47(\mathrm{~m}, 1 \mathrm{H}), 3.45-3.37(\mathrm{~m}, 1 \mathrm{H}), 2.97$ (br s, 2H), 2.66-2.57 (m, 1H), 2.56-2.49 (m, 1H), 2.43-2.36 (m, 2H), $2.20(\mathrm{ddd}, J=12.1,4.8,2.6 \mathrm{~Hz}, 1 \mathrm{H}), 2.05-1.93(\mathrm{~m}, 3 \mathrm{H}), 1.93-$ $1.83(\mathrm{~m}, 2 \mathrm{H}), 1.76-1.43(\mathrm{~m}, 5 \mathrm{H}) ;{ }^{13} \mathrm{C} \mathrm{NMR}\left(125 \mathrm{MHz}, \mathrm{CDCl}_{3}\right) \delta 210.8,172.3,151.1$, $109.5,76.6,69.1,68.3,65.7,58.3,46.1,43.9,41.9,35.6,34.5,33.5,26.4,26.2,25.0$; HRESIMS $m / z$ Calcd for $\mathrm{C}_{18} \mathrm{H}_{24} \mathrm{O}_{4} \mathrm{Na}[\mathrm{M}+\mathrm{Na}]^{+}:$327.1567, Found: 327.1570 .

Compound 18r. White powder (77\% yield); m.p. $126-127{ }^{\circ} \mathrm{C} ;{ }^{1} \mathrm{H}$ NMR $(500 \mathrm{MHz}$, $\left.\mathrm{CDCl}_{3}\right) \delta 5.58-5.47(\mathrm{~m}, 1 \mathrm{H}), 5.17(\mathrm{~d}, J=2.2 \mathrm{~Hz}, 1 \mathrm{H}), 4.89(\mathrm{~d}, J=1.1 \mathrm{~Hz}, 1 \mathrm{H}), 4.36(\mathrm{br}$ s, 1H), 3.74 (br s, 1H), $3.11($ br s, $1 \mathrm{H}), 2.98(\mathrm{~d}, J=5.6 \mathrm{~Hz}, 1 \mathrm{H}), 2.94(\mathrm{~d}, J=3.7 \mathrm{~Hz}$ 1H), 2.81 (br s, 1H), 2.64-2.59 (m, 1H), 2.50-2.45 (m, 1H), 2.43-2.34 (m, 2H), 2.20$2.13(\mathrm{~m}, 1 \mathrm{H}), 2.09(\mathrm{~s}, 3 \mathrm{H}), 2.02-1.93(\mathrm{~m}, 2 \mathrm{H}), 1.90-1.84(\mathrm{~m}, 4 \mathrm{H}), 1.71(\mathrm{~d}, J=11.9 \mathrm{~Hz}$, $1 \mathrm{H}), 1.68-1.53(\mathrm{~m}, 2 \mathrm{H}), 1.48(\mathrm{ddd}, J=13.7,9.6,8.3 \mathrm{~Hz}, 1 \mathrm{H}) ;{ }^{13} \mathrm{C}$ NMR $(100 \mathrm{MHz}$, $\left.\mathrm{CDCl}_{3}\right) \delta 210.6,173.2,169.4,151.1,109.5,77.4,65.6,58.3,46.1,43.9,41.1,35.5$, 34.5, 33.4, 28.5, 28.4, 28.1 (2C), 26.3, 21.3; HRESIMS $m / z$ Calcd for $\mathrm{C}_{20} \mathrm{H}_{27} \mathrm{NO}_{4} \mathrm{Na}$ $[\mathrm{M}+\mathrm{Na}]^{+}:$368.1832, Found: 368.1828 . 
Compound 19a. Colourless oil (54\% yield); ${ }^{1} \mathrm{H}$ NMR (600 MHz, $\left.\mathrm{CDCl}_{3}\right) \delta 5.02$ (s, 1H), $4.92(\mathrm{~d}, J=1.0 \mathrm{~Hz}, 1 \mathrm{H}), 4.01(\mathrm{dd}, J=12.9,6.3 \mathrm{~Hz}, 1 \mathrm{H}), 3.64(\mathrm{dd}, J=10.3,5.8$ $\mathrm{Hz}, 1 \mathrm{H}), 2.64$ (br s, 1H), $2.54(\mathrm{~d}, J=5.4 \mathrm{~Hz}, 1 \mathrm{H}), 2.15-2.02(\mathrm{~m}, 2 \mathrm{H}), 1.98-1.94 \quad(\mathrm{~m}$, 1H), 1.74-1.67 (m, 3H), $1.61(\mathrm{ddd}, J=11.7,4.9,2.3 \mathrm{~Hz}, 1 \mathrm{H}), 1.58-1.47$ (m, 2H), 1.36$1.22(\mathrm{~m}, 2 \mathrm{H}), 1.18(\mathrm{~d}, J=11.6 \mathrm{~Hz}, 1 \mathrm{H}) ;{ }^{13} \mathrm{C} \mathrm{NMR}\left(150 \mathrm{MHz}, \mathrm{CDCl}_{3}\right) \delta 157.5,105.3$, 79.7, 73.3, 56.6, 55.6, 45.1, 43.0, 36.4, 32.4, 30.5, 27.9; HRESIMS $\mathrm{m} / \mathrm{z}$ Calcd for $\mathrm{C}_{12} \mathrm{H}_{18} \mathrm{O}_{2} \mathrm{Na}[\mathrm{M}+\mathrm{Na}]^{+}:$217.1199;, Found: 217.1196.

Compound 19ק. Colourless oil (33\% yield); ${ }^{1} \mathrm{H}$ NMR (600 MHz, $\left.\mathrm{CDCl}_{3}\right) \delta 5.03$ (s, 1H), $4.96(\mathrm{~s}, 1 \mathrm{H}), 4.05(\mathrm{dd}, J=13.1,6.5 \mathrm{~Hz}, 1 \mathrm{H}), 3.78(\mathrm{~s}, 1 \mathrm{H}), 2.71(\mathrm{~s}, 1 \mathrm{H}), 2.29(\mathrm{~d}, J=$ $6.0 \mathrm{~Hz}, 1 \mathrm{H}), 2.16-2.11(\mathrm{~m}, 1 \mathrm{H}), 1.87(\mathrm{~d}, J=11.1 \mathrm{~Hz}, 1 \mathrm{H}), 1.76-1.70(\mathrm{~m}, 4 \mathrm{H}), 1.63-$ $1.54(\mathrm{~m}, 4 \mathrm{H}), 1.44-1.40(\mathrm{~m}, 1 \mathrm{H}), 1.29-1.26(\mathrm{~m}, 1 \mathrm{H}) ;{ }^{13} \mathrm{C} \mathrm{NMR}\left(150 \mathrm{MHz}, \mathrm{CDCl}_{3}\right) \delta$ 156.9, 105.8, 79.6, 75.7, 60.7, 56.3, 45.9, 36.7, 35.8, 31.4, 29.2, 28.5; HRESIMS $m / z$ Calcd for $\mathrm{C}_{12} \mathrm{H}_{18} \mathrm{O}_{2} \mathrm{Na}[\mathrm{M}+\mathrm{Na}]^{+}:$217.1199, Found: 217.1201.

Compound 20a. Colourless oil (40\% yield); ${ }^{1} \mathrm{H}$ NMR (600 MHz, $\left.\mathrm{CDCl}_{3}\right) \delta 5.05$ (s, $1 \mathrm{H}), 4.94(\mathrm{~d}, J=0.9 \mathrm{~Hz}, 1 \mathrm{H}), 4.91(\mathrm{dd}, J=11.6,5.5 \mathrm{~Hz}, 1 \mathrm{H}), 3.69(\mathrm{dd}, J=10.3,5.8$ $\mathrm{Hz}, 1 \mathrm{H}), 2.73(\mathrm{~d}, J=3.3 \mathrm{~Hz}, 1 \mathrm{H}), 2.65(\mathrm{~d}, J=3.2 \mathrm{~Hz}, 1 \mathrm{H}), 2.27-2.17(\mathrm{~m}, 3 \mathrm{H}), 2.17-$ $2.03(\mathrm{~m}, 2 \mathrm{H}), 1.99-1.95(\mathrm{~m}, 1 \mathrm{H}), 1.75-1.69(\mathrm{~m}, 1 \mathrm{H}), 1.66-1.63(\mathrm{~m}, 1 \mathrm{H}), 1.59-1.52(\mathrm{~m}$, 2H), 1.39-1.34 (m, 1H), 1.31-1.20 (m, 1H), $1.16(\mathrm{~d}, J=12.0 \mathrm{~Hz}, 1 \mathrm{H}), 0.97(\mathrm{dd}, J=6.5$, $0.9 \mathrm{~Hz}, 6 \mathrm{H})$ (signal due to hydroxyl proton not observed); ${ }^{13} \mathrm{C} \mathrm{NMR}\left(150 \mathrm{MHz}, \mathrm{CDCl}_{3}\right)$ $\delta 173.1,156.5,106.6,81.7,72.9,56.6,52.8,45.0,44.0,42.0,32.8,32.2,30.6,28.2$, 26.0, 22.6, 22.5; HRESIMS $m / z$ Calcd for $\mathrm{C}_{17} \mathrm{H}_{26} \mathrm{O}_{3} \mathrm{Na}[\mathrm{M}+\mathrm{Na}]^{+}:$301.1774, Found: 301.1794 .

Compound 20ß. Colourless oil (55\% yield); ${ }^{1} \mathrm{H}$ NMR $\left(600 \mathrm{MHz}, \mathrm{CDCl}_{3}\right) \delta 5.08$ (s, $1 \mathrm{H}), 5.02(\mathrm{t}, J=1.1 \mathrm{~Hz}, 1 \mathrm{H}), 4.94-4.91(\mathrm{~m}, 1 \mathrm{H}), 3.78(\mathrm{~s}, 1 \mathrm{H}), 2.71($ br s, $1 \mathrm{H}), 2.46(\mathrm{~d}, J$ $=2.3 \mathrm{~Hz}, 1 \mathrm{H}), 2.27-2.20(\mathrm{~m}, 1 \mathrm{H}), 2.19(\mathrm{~d}, J=2.3 \mathrm{~Hz}, 1 \mathrm{H}), 2.18(\mathrm{~d}, J=1.1 \mathrm{~Hz}, 1 \mathrm{H})$, 
2.16-2.08 (m, 1H), 1.87-1.82 (m, 1H), 1.79-1.66 (m, 5H), 1.59-1.56 (m, 1H), 1.47$1.41(\mathrm{~m}, 1 \mathrm{H}), 1.30(\mathrm{dd}, J=11.6,5.0 \mathrm{~Hz}, 1 \mathrm{H}), 0.97(\mathrm{dd}, J=6.5,1.2 \mathrm{~Hz}, 6 \mathrm{H})$ (signal due to hydroxyl proton not observed); ${ }^{13} \mathrm{C} \mathrm{NMR}\left(150 \mathrm{MHz}, \mathrm{CDCl}_{3}\right) \delta 173.0,155.8,107.3$, $81.9,75.8,58.2,56.6,45.8,43.9,35.5,32.7,32.2,29.1,28.8,26.0,22.6,22.5$; HRESIMS $m / z$ Calcd for $\mathrm{C}_{17} \mathrm{H}_{26} \mathrm{O}_{3} \mathrm{Na}[\mathrm{M}+\mathrm{Na}]^{+}: 301.1774$, Found: 301.1785 .

Compound 21 $\alpha$. Colourless oil (39\% yield); ${ }^{1} \mathrm{H}$ NMR $\left(600 \mathrm{MHz}, \mathrm{CDCl}_{3}\right) \delta 5.05$ (s, 1H), $4.94(\mathrm{~s}, 1 \mathrm{H}), 4.93-4.90(\mathrm{~m}, 2 \mathrm{H}), 4.86(\mathrm{~s}, 1 \mathrm{H}), 3.69(\mathrm{dd}, J=10.3,5.8 \mathrm{~Hz}, 1 \mathrm{H}), 3.04$ (s, 2H), $2.73(\mathrm{~d}, J=3.1 \mathrm{~Hz}, 1 \mathrm{H}), 2.65(\mathrm{~d}, J=3.2 \mathrm{~Hz}, 1 \mathrm{H}), 2.25-2.21(\mathrm{~m}, 1 \mathrm{H}), 2.07$ (dt, $J$ $=12.9,8.3 \mathrm{~Hz}, 1 \mathrm{H}), 1.99-1.95(\mathrm{~m}, 1 \mathrm{H}), 1.82(\mathrm{~s}, 3 \mathrm{H}), 1.76-1.71(\mathrm{~m}, 1 \mathrm{H}), 1.64(\mathrm{ddd}, J=$ 11.8, 5.0, $2.2 \mathrm{~Hz}, 1 \mathrm{H}), 1.58-1.51(\mathrm{~m}, 2 \mathrm{H}), 1.37(\mathrm{ddd}, J=12.9,7.4,5.6 \mathrm{~Hz}, 1 \mathrm{H}), 1.32-$ $1.20(\mathrm{~m}, 1 \mathrm{H}), 1.16(\mathrm{~d}, J=11.8 \mathrm{~Hz}, 1 \mathrm{H})$ (signal due to hydroxyl proton not observed); ${ }^{13} \mathrm{C} \mathrm{NMR}\left(150 \mathrm{MHz}, \mathrm{CDCl}_{3}\right) \delta 171.4,156.3,138.9,114.7,106.8,82.2,72.9,56.6,52.8$, 45.0, 44.0, 42.0, 32.7, 32.2, 30.6, 28.2, 22.7; HRESIMS $m / z$ Calcd for $\mathrm{C}_{17} \mathrm{H}_{24} \mathrm{O}_{3} \mathrm{Na}$ $[\mathrm{M}+\mathrm{Na}]^{+}:$299.1618, Found: 299.1629.

Compound 21ß. Colourless oil (53\% yield); ${ }^{1} \mathrm{H}$ NMR $\left(600 \mathrm{MHz}, \mathrm{CDCl}_{3}\right) \delta 5.08$ (s, 1H), 5.03-4.99 (t, $J=1.2 \mathrm{~Hz}, 1 \mathrm{H}), 4.93(\mathrm{dd}, J=4.8,1.7 \mathrm{~Hz}, 1 \mathrm{H}), 4.92(\mathrm{t}, J=1.7 \mathrm{~Hz}$, 1H), $4.86(\mathrm{~s}, 1 \mathrm{H}), 3.78(\mathrm{~s}, 1 \mathrm{H}), 3.03(\mathrm{~s}, 2 \mathrm{H}), 2.71(\mathrm{br} \mathrm{s}, 1 \mathrm{H}), 2.46(\mathrm{~d}, J=2.3 \mathrm{~Hz}, 1 \mathrm{H})$, 2.31-2.15 (m, 1H), $1.85(\mathrm{dd}, J=11.7,1.0 \mathrm{~Hz}, 1 \mathrm{H}), 1.82(\mathrm{~s}, 3 \mathrm{H}), 1.79-1.64(\mathrm{~m}, 5 \mathrm{H})$, $1.58-1.55(\mathrm{~m}, 1 \mathrm{H}), 1.46-1.41(\mathrm{~m}, 1 \mathrm{H}), 1.30(\mathrm{dd}, J=11.6,5.0 \mathrm{~Hz}, 1 \mathrm{H})$ (signal due to hydroxyl proton not observed); ${ }^{13} \mathrm{C}$ NMR $\left(150 \mathrm{MHz}, \mathrm{CDCl}_{3}\right) \delta 171.2,155.6,138.8$, $114.7,107.4,82.4,75.7,58.2,56.6,45.8,44.0,35.5,32.6,32.2,29.1,28.8,22.7$; HRESIMS $m / z$ Calcd for $\mathrm{C}_{17} \mathrm{H}_{24} \mathrm{O}_{3} \mathrm{Na}[\mathrm{M}+\mathrm{Na}]^{+}:$299.1618, Found: 299.1612.

Compound 22 $\alpha$. Mixture of diastereomers, colourless oil (37\% yield); ${ }^{1} \mathrm{H}$ NMR (600 $\left.\mathrm{MHz}, \mathrm{CDCl}_{3}\right) \delta 5.04(\mathrm{~s}, 1 \mathrm{H}), 4.94(\mathrm{~s}, 1 \mathrm{H}), 4.90(\mathrm{q}, J=5.8 \mathrm{~Hz}, 1 \mathrm{H}), 3.69(\mathrm{dd}, J=10.3$, $5.9 \mathrm{~Hz}, 1 \mathrm{H}), 2.73$ (br s, 1H), 2.65 (br s, 1H), 2.39-2.33 (m, 1H), 2.25-2.18 (m, 1H), 
2.09-2.04 (m, 1H), 2.02-1.94 (m, 1H), 1.80-1.63 (m, 3H), 1.55 (br s, 3H), 1.51-1.44 (m, 1H), 1.42-1.33 (m, 1H), 1.30-1.22 (m, 1H), 1.15 (dd, $J=7.0,3.7 \mathrm{~Hz}, 3 \mathrm{H}), 0.92(\mathrm{td}$, $J=7.4,4.1 \mathrm{~Hz}, 3 \mathrm{H})$ (signal due to hydroxyl proton not observed); ${ }^{13} \mathrm{C}$ NMR (150 MHz, $\left.\mathrm{CDCl}_{3}\right) \delta 176.7,156.5,106.6,81.6(2 \mathrm{C}), 72.9,56.5,52.7,45.0,42.2,41.4,32.9,32.2$ 30.6, 28.2, 27.0, 26.9, 16.8, 16.7, 11.8; HRESIMS $m / z$ Calcd for $\mathrm{C}_{17} \mathrm{H}_{26} \mathrm{O}_{3} \mathrm{Na}[\mathrm{M}+\mathrm{Na}]^{+}$: 301.1774, Found: 301.1782.

Compound 22 $\beta$. Colourless oil (57\% yield); ${ }^{1} \mathrm{H}$ NMR (500 MHz, $\left.\mathrm{CDCl}_{3}\right) \delta 5.06$ (s, 1H), $4.98(\mathrm{~d}, J=1.0 \mathrm{~Hz}, 1 \mathrm{H}), 4.95-4.83(\mathrm{~m}, 1 \mathrm{H}), 3.76(\mathrm{~s}, 1 \mathrm{H}), 2.70$ (br s, 1H), 2.44 (br s, $1 \mathrm{H}), 2.38-2.34(\mathrm{~m}, 1 \mathrm{H}), 2.26-2.14(\mathrm{~m}, 1 \mathrm{H}), 1.84(\mathrm{dd}, J=11.6,1.5 \mathrm{~Hz}, 1 \mathrm{H}), 1.77-$ $1.63(\mathrm{~m}, 5 \mathrm{H}), 1.63-1.53(\mathrm{~m}, 2 \mathrm{H}), 1.51-1.39(\mathrm{~m}, 2 \mathrm{H}), 1.30(\mathrm{dd}, J=11.7,5.1 \mathrm{~Hz}, 1 \mathrm{H})$, $1.13(\mathrm{dd}, J=7.0,2.8 \mathrm{~Hz}, 3 \mathrm{H}), 0.90(\mathrm{td}, J=7.4,2.4 \mathrm{~Hz}, 3 \mathrm{H})$ (signal due to hydroxyl proton not observed); ${ }^{13} \mathrm{C} \mathrm{NMR}\left(125 \mathrm{MHz}, \mathrm{CDCl}_{3}\right) \delta 176.5,155.7,107.3,81.7,75.8$, $58.2,58.1,56.5,45.8,41.3,35.6,32.7,32.6,32.2,29.1,28.8,27.0,26.9,16.8,16.7$, 11.7; HRESIMS $m / z$ Calcd for $\mathrm{C}_{17} \mathrm{H}_{26} \mathrm{O}_{3} \mathrm{Na}[\mathrm{M}+\mathrm{Na}]^{+}: 301.1774$, Found: 301.1783 .

Compound 23a. Colourless oil (38\% yield); ${ }^{1} \mathrm{H}$ NMR (600 MHz, $\left.\mathrm{CDCl}_{3}\right) \delta 5.04$ (s, $1 \mathrm{H}), 4.94(\mathrm{~d}, J=0.9 \mathrm{~Hz}, 1 \mathrm{H}), 4.90(\mathrm{q}, J=5.8 \mathrm{~Hz}, 1 \mathrm{H}), 3.69(\mathrm{dd}, J=10.2,5.8 \mathrm{~Hz}, 1 \mathrm{H})$, 2.73 (br s, 1H), 2.65 (d, $J=3.2 \mathrm{~Hz}, 1 \mathrm{H}), 2.39-2.36(\mathrm{~m}, 1 \mathrm{H}), 2.28-2.17(\mathrm{~m}, 1 \mathrm{H}), 2.07$ $(\mathrm{dt}, J=12.9,8.2 \mathrm{~Hz}, 1 \mathrm{H}), 1.99-1.95(\mathrm{~m}, 1 \mathrm{H}), 1.77-1.62(\mathrm{~m}, 3 \mathrm{H}), 1.58-1.51(\mathrm{~m}, 2 \mathrm{H})$, $1.49(\mathrm{ddd}, J=20.4,10.5,4.7 \mathrm{~Hz}, 2 \mathrm{H}), 1.37(\mathrm{ddd}, J=13.1,7.3,6.1 \mathrm{~Hz}, 1 \mathrm{H}), 1.31-1.21$ $(\mathrm{m}, 1 \mathrm{H}), 1.15(\mathrm{dd}, J=7.0,3.6 \mathrm{~Hz}, 3 \mathrm{H}), 0.92(\mathrm{td}, J=7.4,4.1 \mathrm{~Hz}, 3 \mathrm{H})$ (signal due to hydroxyl proton not observed); ${ }^{13} \mathrm{C}$ NMR (150 MHz, $\left.\mathrm{CDCl}_{3}\right) \delta 176.7,156.5(2 \mathrm{C}), 106.6$ (2C), $81.6(2 \mathrm{C}), 72.9,56.5,52.7,45.0,42.2,42.1,41.4,32.9,32.8,32.2,30.6,28.2$, 27.0, 26.9, 16.8, 16.7, 11.8; HRESIMS $m / z$ Calcd for $\mathrm{C}_{17} \mathrm{H}_{26} \mathrm{O}_{3} \mathrm{Na}[\mathrm{M}+\mathrm{Na}]^{+}:$301.1774, Found: 301.1775. 
Compound 23ß. Colourless oil (56\% yield); ${ }^{1} \mathrm{H}$ NMR (600 MHz, $\left.\mathrm{CDCl}_{3}\right) \delta 5.07$ (s, 1H), $4.99 \mathrm{~d}, J=0.7 \mathrm{~Hz}, 1 \mathrm{H}), 4.96-4.86(\mathrm{~m}, 1 \mathrm{H}), 3.78$ (s, 1H), 2.72 (br s, 1H), 2.46 (br s, 1H), 2.38-2.32 (m, 1H), 2.25-2.20 (m, 1H), $1.85(\mathrm{dd}, J=11.6,1.0 \mathrm{~Hz}, 1 \mathrm{H}), 1.78-1.65$ (m, 5H), 1.59-1.56 (m, 2H), 1.53-1.40 (m, 2H), $1.31(\mathrm{dd}, J=11.6,5.0 \mathrm{~Hz}, 1 \mathrm{H}), 1.15$ $(\mathrm{dd}, J=7.0,3.5 \mathrm{~Hz}, 3 \mathrm{H}), 0.92(\mathrm{dd}, J=8.9,6.0 \mathrm{~Hz}, 3 \mathrm{H})$ (signal due to hydroxyl proton not observed); ${ }^{13} \mathrm{C}$ NMR $\left(150 \mathrm{MHz}, \mathrm{CDCl}_{3}\right) \delta 176.5,155.8,107.3,81.8(2 \mathrm{C}), 75.8$, $58.2,56.5,45.8,41.4,35.6,32.7,32.6,32.2,29.1,28.8,27.0,26.9,16.8,16.7,11.8$; HRESIMS $m / z$ Calcd for $\mathrm{C}_{17} \mathrm{H}_{26} \mathrm{O}_{3} \mathrm{Na}[\mathrm{M}+\mathrm{Na}]^{+}: 301.1774$, Found: 301.1778 .

Compound 24a. Colourless oil (40\% yield); ${ }^{1} \mathrm{H}$ NMR $\left(600 \mathrm{MHz}, \mathrm{CDCl}_{3}\right) \delta 7.28(\mathrm{dd}, J$ $=10.6,4.5 \mathrm{~Hz}, 1 \mathrm{H}), 7.24(\mathrm{dd}, J=7.5,1.8 \mathrm{~Hz}, 1 \mathrm{H}), 7.10(\mathrm{t}, J=7.4 \mathrm{~Hz}, 1 \mathrm{H}), 7.06(\mathrm{t}, J=$ $9.1 \mathrm{~Hz}, 1 \mathrm{H}), 4.97(\mathrm{~s}, 1 \mathrm{H}), 4.94-4.91(\mathrm{~m}, 1 \mathrm{H}), 4.91(\mathrm{~s}, 1 \mathrm{H}), 3.68(\mathrm{~s}, 2 \mathrm{H}), 3.68-3.63(\mathrm{~m}$, $1 \mathrm{H}), 2.68(\mathrm{~d}, J=2.7 \mathrm{~Hz}, 1 \mathrm{H}), 2.63(\mathrm{~d}, J=3.4 \mathrm{~Hz}, 1 \mathrm{H}), 2.25-2.17(\mathrm{~m}, 1 \mathrm{H}), 2.04(\mathrm{dt}, J=$ 12.9, 8.3 Hz, 1H), 2.00-1.93 (m, 1H), 1.76-1.71 (m, 1H), $1.62(\mathrm{ddd}, J=11.9,5.0,2.1$ $\mathrm{Hz}, 1 \mathrm{H}), 1.58-1.50(\mathrm{~m}, 2 \mathrm{H}), 1.36(\mathrm{ddd}, J=12.8,7.4,5.4 \mathrm{~Hz}, 1 \mathrm{H}), 1.28-1.18(\mathrm{~m}, 1 \mathrm{H})$, $1.15(\mathrm{~d}, J=11.8 \mathrm{~Hz}, 1 \mathrm{H})$ (signal due to hydroxyl proton not observed); ${ }^{13} \mathrm{C}$ NMR (150 $\left.\mathrm{MHz}, \mathrm{CDCl}_{3}\right) \delta 170.6,161.2(\mathrm{~d}, J=247 \mathrm{~Hz}), 156.1,131.6(\mathrm{~d}, J=4 \mathrm{~Hz}), 129.1(\mathrm{~d}, J=8$ Hz), $124.2(\mathrm{~d}, J=4 \mathrm{~Hz}), 121.12$ (d, $J=8 \mathrm{~Hz}), 115.5$ (d, $J=21 \mathrm{~Hz}), 106.8,82.6,72.9$, 56.6, 52.8, 44.9, 42.0, 35.1, 32.6, 32.1, 30.7, 28.1; HRESIMS $\mathrm{m} / \mathrm{z}$ Calcd for $\mathrm{C}_{20} \mathrm{H}_{23} \mathrm{FO}_{3} \mathrm{Na}[\mathrm{M}+\mathrm{Na}]^{+}:$353.1523, Found: 353.1528 .

Compound 24ß. Colourless oil (49\% yield); ${ }^{1} \mathrm{H}$ NMR (600 MHz, $\left.\mathrm{CDCl}_{3}\right) \delta 7.29-7.23$ (m, 2H), $7.10(\mathrm{dd}, J=10.8,4.1 \mathrm{~Hz}, 1 \mathrm{H}), 7.06(\mathrm{t}, J=8.9 \mathrm{~Hz}, 1 \mathrm{H}), 5.01(\mathrm{~s}, 1 \mathrm{H}), 4.96(\mathrm{~d}, J$ $=0.9 \mathrm{~Hz}, 1 \mathrm{H}), 4.94-4.92(\mathrm{~m}, 1 \mathrm{H}), 3.73(\mathrm{~s}, 1 \mathrm{H}), 3.67(\mathrm{~s}, 2 \mathrm{H}), 2.69(\mathrm{br} \mathrm{s}, 1 \mathrm{H}), 2.42(\mathrm{br} \mathrm{s}$, 1H), 2.24-2.17 (m, 1H), $1.83(\mathrm{~d}, J=11.6 \mathrm{~Hz}, 1 \mathrm{H}), 1.78-1.54(\mathrm{~m}, 6 \mathrm{H}), 1.44-1.40(\mathrm{~m}$, 1H), 1.29-1.25 (m, 1H) (signal due to hydroxyl proton not observed); ${ }^{13} \mathrm{C}$ NMR (150 $\left.\mathrm{MHz}_{\mathrm{CDCl}}\right) \delta 170.5,161.2(\mathrm{~d}, J=246 \mathrm{~Hz}), 155.47,131.5(\mathrm{~d}, J=4 \mathrm{~Hz}), 129.2(\mathrm{~d}, J=$ 
$8 \mathrm{~Hz}), 124.2(\mathrm{~d}, J=4 \mathrm{~Hz}), 121.7(\mathrm{~d}, J=16 \mathrm{~Hz}), 115.5(\mathrm{~d}, J=22 \mathrm{~Hz}), 107.4,82.8,75.7$, 58.2, 56.6, 45.7, 35.4, $35.1(\mathrm{~d}, J=2.5), 32.5,32.2,29.1,28.8$; HRESIMS $m / z$ Calcd for $\mathrm{C}_{20} \mathrm{H}_{23} \mathrm{FO}_{3} \mathrm{Na}[\mathrm{M}+\mathrm{Na}]^{+}:$353.1523, Found: 353.1524 .

Compound 25a. Colourless oil (37\% yield); ${ }^{1} \mathrm{H}$ NMR (600 MHz, $\left.\mathrm{CDCl}_{3}\right) \delta 7.31-7.27$ $(\mathrm{m}, 1 \mathrm{H}), 7.07(\mathrm{~d}, J=7.6 \mathrm{~Hz}, 1 \mathrm{H}), 7.04-7.02(\mathrm{~m}, 1 \mathrm{H}), 6.96(\mathrm{td}, J=8.5,2.1 \mathrm{~Hz}, 1 \mathrm{H})$, $4.91(\mathrm{~m}, 3 \mathrm{H}), 3.68(\mathrm{dd}, J=10.2,5.8 \mathrm{~Hz}, 1 \mathrm{H}), 3.62(\mathrm{~s}, 2 \mathrm{H}), 2.69($ br s, $1 \mathrm{H}), 2.63(\mathrm{~d}, J=$ $3.2 \mathrm{~Hz}, 1 \mathrm{H}), 2.22-2.16(\mathrm{~m}, 1 \mathrm{H}), 2.06(\mathrm{dt}, J=12.8,8.4 \mathrm{~Hz}, 1 \mathrm{H}), 1.98-1.94(\mathrm{~m}, 1 \mathrm{H})$, $1.75-1.70(\mathrm{~m}, 1 \mathrm{H}), 1.62(\mathrm{ddd}, J=11.8,4.9,1.9 \mathrm{~Hz}, 1 \mathrm{H}), 1.57-1.50(\mathrm{~m}, 2 \mathrm{H}), 1.36$ (ddd, $J=12.8,7.3,5.4 \mathrm{~Hz}, 1 \mathrm{H}), 1.29-1.18(\mathrm{~m}, 1 \mathrm{H}), 1.15(\mathrm{~d}, J=11.8 \mathrm{~Hz}, 1 \mathrm{H})$ (signal due to hydroxyl proton not observed); ${ }^{13} \mathrm{C}$ NMR $\left(150 \mathrm{MHz}, \mathrm{CDCl}_{3}\right) \delta 170.9,163.0(\mathrm{~d}, J=246$ Hz), 156.2, 136.7 (d, $J=8 \mathrm{~Hz}), 130.1(\mathrm{~d}, J=9 \mathrm{~Hz}), 125.1$ (d, $J=3 \mathrm{~Hz}), 116.4(\mathrm{~d}, J=22$ Hz), $114.2(\mathrm{~d}, J=21 \mathrm{~Hz}), 106.8,82.7,72.8,56.7,52.8,44.9,41.9,41.6,32.6,32.1$, 30.6, 28.2; HRESIMS $m / z$ Calcd for $\mathrm{C}_{20} \mathrm{H}_{23} \mathrm{FO}_{3} \mathrm{Na}[\mathrm{M}+\mathrm{Na}]^{+}$: 353.1523, Found: 353.1536.

Compound 25ß. Colourless oil (53\% yield); ${ }^{1} \mathrm{H}$ NMR $\left(600 \mathrm{MHz}, \mathrm{CDCl}_{3}\right) \delta 7.28(\mathrm{~m}$, 1H), $7.06(\mathrm{~d}, J=7.6 \mathrm{~Hz}, 1 \mathrm{H}), 7.02(\mathrm{dd}, J=9.7,1.3 \mathrm{~Hz}, 1 \mathrm{H}), 6.97(\mathrm{t}, J=8.5 \mathrm{~Hz}, 1 \mathrm{H})$, $4.97(\mathrm{~s}, 1 \mathrm{H}), 4.96(\mathrm{~s}, 1 \mathrm{H}), 4.93(\mathrm{dd}, J=7.5,2.9 \mathrm{~Hz}, 1 \mathrm{H}), 3.74(\mathrm{~s}, 1 \mathrm{H}), 3.61(\mathrm{~s}, 2 \mathrm{H}), 2.69$ (br s, 1H), $2.41($ br s, 1H), 2.27-2.13 (m, 1H), $1.84(\mathrm{~d}, J=11.6 \mathrm{~Hz}, 1 \mathrm{H}), 1.77-1.62(\mathrm{~m}$, 5H), 1.57-1.54 (m, 1H), 1.47-1.39 (m, 1H), 1.34-1.24 (m, 1H) (signal due to hydroxyl proton not observed); ${ }^{13} \mathrm{C} \mathrm{NMR}\left(151 \mathrm{MHz}, \mathrm{CDCl}_{3}\right) \delta 170.7,163.0(\mathrm{~d}, J=246 \mathrm{~Hz})$, 155.5, $136.6(\mathrm{~d}, J=7 \mathrm{~Hz}), 130.1(\mathrm{~d}, J=9 \mathrm{~Hz}), 125.1(\mathrm{~d}, J=3 \mathrm{~Hz}), 116.4(\mathrm{~d}, J=22 \mathrm{~Hz})$, $114.2(\mathrm{~d}, J=21 \mathrm{~Hz}), 107.5,82.8,75.7,58.2,56.6,45.7,41.6,35.5,32.5,32.2,29.0$, 28.8; HRESIMS $m / z$ Calcd for $\mathrm{C}_{20} \mathrm{H}_{23} \mathrm{FO}_{3} \mathrm{Na}[\mathrm{M}+\mathrm{Na}]^{+}:$353.1523, Found: 353.1535 .

Compound 26a. Colourless oil (62\% yield); ${ }^{1} \mathrm{H}$ NMR $\left(500 \mathrm{MHz}, \mathrm{CDCl}_{3}\right) \delta 5.04$ (s, 1H), 4.97-4.93 (m, 1H), $4.90(\mathrm{dd}, J=11.6,5.3 \mathrm{~Hz}, 1 \mathrm{H}), 3.95(\mathrm{dd}, J=11.8,4.4 \mathrm{~Hz}, 2 \mathrm{H})$, 
$3.70(\mathrm{dd}, J=10.3,5.8 \mathrm{~Hz}, 1 \mathrm{H}), 3.41(\mathrm{tt}, J=11.9,2.1 \mathrm{~Hz}, 2 \mathrm{H}), 2.72(\mathrm{~d}, J=2.6 \mathrm{~Hz}, 1 \mathrm{H})$, $2.65(\mathrm{~d}, J=3.7 \mathrm{~Hz}, 1 \mathrm{H}), 2.26(\mathrm{dd}, J=7.2,2.4 \mathrm{~Hz}, 2 \mathrm{H}), 2.25-2.16(\mathrm{~m}, 2 \mathrm{H}), 2.11-2.02$ (m, 2H), 2.02-1.95 (m, 1H), 1.77-1.68 (m, 1H), $1.64(\mathrm{ddd}, J=7.1,6.6,2.4 \mathrm{~Hz}, 3 \mathrm{H})$, $1.37(\mathrm{ddd}, J=11.9,8.6,4.7 \mathrm{~Hz}, 3 \mathrm{H}), 1.29-1.20(\mathrm{~m}, 2 \mathrm{H}), 1.17(\mathrm{dd}, J=11.8,1.5 \mathrm{~Hz}, 1 \mathrm{H})$ (signal due to hydroxyl proton not observed); ${ }^{13} \mathrm{C} \mathrm{NMR}\left(125 \mathrm{MHz}, \mathrm{CDCl}_{3}\right) \delta 172.4$, $156.4,106.7,82.0,77.4,72.8,67.9$ (2C), 56.6, 52.8, 44.9, 41.9, 32.9, 32.8, 32.8, 32.3, 32.1, 30.6, 28.2; HRESIMS $m / z$ Calcd for $\mathrm{C}_{19} \mathrm{H}_{28} \mathrm{O}_{4} \mathrm{Na}[\mathrm{M}+\mathrm{Na}]^{+}$: 343.1880, Found: 343.1884 .

Compound 26ק. Colourless oil (33\% yield); ${ }^{1} \mathrm{H}$ NMR $\left(600 \mathrm{MHz}, \mathrm{CDCl}_{3}\right) \delta 5.06$ (s, $1 \mathrm{H}), 5.02-4.98(\mathrm{~m}, 1 \mathrm{H}), 4.94-4.91(\mathrm{~m}, 1 \mathrm{H}), 3.95(\mathrm{dd}, J=11.2,3.6 \mathrm{~Hz}, 2 \mathrm{H}), 3.78(\mathrm{~s}$, 1H), 3.41 (ddd, $J=11.8,9.9,2.2 \mathrm{~Hz}, 2 \mathrm{H}), 2.72($ br s, $1 \mathrm{H}), 2.45(\mathrm{~d}, J=2.4 \mathrm{~Hz}, 1 \mathrm{H})$, 2.29-2.19 (m, 3H), 2.06-1.99 (m, 1H), $1.85(\mathrm{dd}, J=11.7,1.0 \mathrm{~Hz}, 1 \mathrm{H}), 1.79-1.67(\mathrm{~m}$, 5H), $1.66(\mathrm{~d}, J=1.7 \mathrm{~Hz}, 1 \mathrm{H}), 1.63(\mathrm{~d}, J=1.5 \mathrm{~Hz}, 1 \mathrm{H}), 1.60-1.57(\mathrm{~m}, 1 \mathrm{H}), 1.46-1.42$ (m, 1H), 1.40-1.28 (m, 3H) (signal due to hydroxyl proton not observed); ${ }^{13} \mathrm{C}$ NMR $\delta$ (150 MHz, $\left.\mathrm{CDCl}_{3}\right)$ 172.2, 155.8, 107.3, 82.2, 75.7, 67.9 (2C), 58.2, 56.6, 45.8, 41.9, 35.5, 32.9 (2C), 32.7, 32.4, 32.2, 29.1, 28.9; HRESIMS $\mathrm{m} / \mathrm{z}$ Calcd for $\mathrm{C}_{19} \mathrm{H}_{28} \mathrm{O}_{4} \mathrm{Na}$ $[\mathrm{M}+\mathrm{Na}]^{+}: 343.1880$, Found: 343.1881.

Compound 27a. Colourless oil (42\% yield); ${ }^{1} \mathrm{H}$ NMR $\left(500 \mathrm{MHz}, \mathrm{CDCl}_{3}\right) \delta 8.07(\mathrm{dd}, J$ $=8.4,1.3 \mathrm{~Hz}, 2 \mathrm{H}), 7.57-7.54(\mathrm{~m}, 1 \mathrm{H}), 7.44(\mathrm{t}, J=7.7 \mathrm{~Hz}, 2 \mathrm{H}), 5.17-5.14(\mathrm{~m}, 1 \mathrm{H}), 5.11$ $(\mathrm{s}, 1 \mathrm{H}), 4.97-4.96(\mathrm{~m}, 1 \mathrm{H}), 3.74(\mathrm{dd}, J=10.3,5.8 \mathrm{~Hz}, 1 \mathrm{H}), 2.91(\mathrm{~d}, J=3.1 \mathrm{~Hz}, 1 \mathrm{H})$, $2.69(\mathrm{~d}, J=3.8 \mathrm{~Hz}, 1 \mathrm{H}), 2.37-2.30(\mathrm{~m}, 1 \mathrm{H}), 2.19-2.13(\mathrm{~m}, 1 \mathrm{H}), 2.03-1.98(\mathrm{~m}, 1 \mathrm{H})$, $1.92-1.86(\mathrm{~m}, 1 \mathrm{H}), 1.71(\mathrm{ddd}, J=11.8,5.0,2.2 \mathrm{~Hz}, 1 \mathrm{H}), 1.60-1.55(\mathrm{~m}, 2 \mathrm{H}), 1.45$ (ddd, $J=12.9,7.4,5.5 \mathrm{~Hz}, 1 \mathrm{H}), 1.34-1.25(\mathrm{~m}, 1 \mathrm{H}), 1.21(\mathrm{dd}, J=11.8,1.5 \mathrm{~Hz}, 1 \mathrm{H})$ (signal due to hydroxyl proton not observed); ${ }^{13} \mathrm{C} \mathrm{NMR}\left(126 \mathrm{MHz}, \mathrm{CDCl}_{3}\right) \delta 166.6,156.3$, 
$133.0,130.8,129.7,128.5,106.9,82.5,73.0,56.6,52.9,45.0,42.1,32.9,32.1,30.6$, 28.3; HRESIMS $m / z$ Calcd for $\mathrm{C}_{19} \mathrm{H}_{22} \mathrm{O}_{3} \mathrm{Na}[\mathrm{M}+\mathrm{Na}]^{+}: 321.1461$, Found: 321.1466.

Compound 27ß. Colourless oil (54\% yield); ${ }^{1} \mathrm{H} \mathrm{NMR}\left(500 \mathrm{MHz}, \mathrm{CDCl}_{3}\right) \delta 8.06(\mathrm{dd}, J$ $=8.4,1.3 \mathrm{~Hz}, 2 \mathrm{H}), 7.56(\mathrm{~m}, 1 \mathrm{H}), 7.48-7.42(\mathrm{~m}, 2 \mathrm{H}), 5.17(\mathrm{~s}, 1 \mathrm{H}), 5.18-5.15(\mathrm{~m}, 1 \mathrm{H})$, 5.04-5.03 (m, 1H), 3.84-3.83 (m, 1H), $2.75($ br s, $1 \mathrm{H}), 2.64(\mathrm{~d}, J=2.4 \mathrm{~Hz}, 1 \mathrm{H}), 2.41-$ $2.27(\mathrm{~m}, 1 \mathrm{H}), 1.97-1.86(\mathrm{~m}, 2 \mathrm{H}), 1.82-1.71(\mathrm{~m}, 4 \mathrm{H}), 1.61-1.58(\mathrm{~m}, 1 \mathrm{H}), 1.49-1.44(\mathrm{~m}$, 1H), 1.37 (dd, $J=11.6,5.1 \mathrm{~Hz}, 1 \mathrm{H})$ (signal due to hydroxyl proton not observed); ${ }^{13} \mathrm{C}$ NMR (126 MHz, $\left.\mathrm{CDCl}_{3}\right) \delta 166.4,155.6,133.0,130.8,129.7$ (2C), 128.5 (2C), 107.6, 82.8, 75.8, 58.4, 56.6, 45.8, 35.5, 32.7, 32.3, 29.1, 28.8; HRESIMS m/z Calcd for $\mathrm{C}_{19} \mathrm{H}_{22} \mathrm{O}_{3} \mathrm{Na}[\mathrm{M}+\mathrm{Na}]^{+}:$321.1461, Found: 321.1467.

Compound 28a. Colourless oil (36\% yield); ${ }^{1} \mathrm{H}$ NMR (500 MHz, $\left.\mathrm{CDCl}_{3}\right) \delta 7.62$ (ddd, $J=8.6,5.5,3.3 \mathrm{~Hz}, 1 \mathrm{H}), 7.23-7.18(\mathrm{~m}, 1 \mathrm{H}), 7.11(\mathrm{td}, J=9.3,4.2 \mathrm{~Hz}, 1 \mathrm{H}), 5.15(\mathrm{~s}, 1 \mathrm{H})$, 5.16-5.13 (m, 1H), $4.99(\mathrm{~d}, J=2.2 \mathrm{~Hz}, 1 \mathrm{H}), 3.73(\mathrm{dd}, J=10.3,5.9 \mathrm{~Hz}, 1 \mathrm{H}), 2.88(\mathrm{~d}, J=$ $2.9 \mathrm{~Hz}, 1 \mathrm{H}), 2.68(\mathrm{~d}, J=3.6 \mathrm{~Hz}, 1 \mathrm{H}), 2.32(\mathrm{dt}, J=13.7,7.6 \mathrm{~Hz}, 1 \mathrm{H}), 2.22-2.11(\mathrm{~m}$, 1H), 2.05-1.96 (m, 1H), 1.93-1.87 (m, 1H), 1.69 (ddd, $J=11.8,5.0,2.1 \mathrm{~Hz}, 1 \mathrm{H}), 1.61-$ $1.55(\mathrm{~m}, 2 \mathrm{H}), 1.44(\mathrm{ddd}, J=12.6,7.3,5.1 \mathrm{~Hz}, 1 \mathrm{H}), 1.32-1.23(\mathrm{~m}, 1 \mathrm{H}), 1.20(\mathrm{~d}, J=10.8$ $\mathrm{Hz}, 1 \mathrm{H})$ (signal due to hydroxyl proton not observed); ${ }^{13} \mathrm{C} \mathrm{NMR}\left(125 \mathrm{MHz}, \mathrm{CDCl}_{3}\right) \delta$ $163.3(\mathrm{~m}), 158.2(\mathrm{dd}, J=253,3 \mathrm{~Hz}), 157.3(\mathrm{dd}, J=247,3 \mathrm{~Hz}), 156.1,121.1(\mathrm{dd}, J=$ 24, $9 \mathrm{~Hz}), 120.5(\mathrm{dd}, J=13,7 \mathrm{~Hz}), 118.5(\mathrm{dd}, J=26,7 \mathrm{~Hz}), 118.3(\mathrm{dd}, J=27,1 \mathrm{~Hz})$, 107.1, 83.4, 72.8, 56.7, 52.9, 44.9, 41.9, 32.7, 32.1, 30.6, 28.2; HRESIMS $m / z$ Calcd for $\mathrm{C}_{19} \mathrm{H}_{20} \mathrm{~F}_{2} \mathrm{O}_{3} \mathrm{Na}[\mathrm{M}+\mathrm{Na}]^{+}:$357.1273, Found: 357.1264 .

Compound 28ß. Colourless oil (64\% yield); ${ }^{1} \mathrm{H}$ NMR $\left(600 \mathrm{MHz}, \mathrm{CDCl}_{3}\right) \delta 7.61$ (ddd, $J$ $=8.6,5.6,3.4 \mathrm{~Hz}, 1 \mathrm{H}), 7.21(\mathrm{ddt}, J=9.0,7.0,3.4 \mathrm{~Hz}, 1 \mathrm{H}), 7.11(\mathrm{td}, J=9.3,4.2 \mathrm{~Hz}$, $1 \mathrm{H}), 5.19(\mathrm{~s}, 1 \mathrm{H}), 5.17-5.15(\mathrm{~m}, 1 \mathrm{H}), 5.05-5.04(\mathrm{~m}, 1 \mathrm{H}), 3.83(\mathrm{~s}, 1 \mathrm{H}), 2.75(\mathrm{~s}, 1 \mathrm{H})$, $2.62(\mathrm{~s}, 1 \mathrm{H}), 2.33(\mathrm{dt}, J=14.3,7.8 \mathrm{~Hz}, 1 \mathrm{H}), 1.96-1.88(\mathrm{~m}, 2 \mathrm{H}), 1.82-1.71(\mathrm{~m}, 4 \mathrm{H})$, 
$1.59(\mathrm{~d}, J=9.3 \mathrm{~Hz}, 1 \mathrm{H}), 1.48-1.44(\mathrm{~m}, 1 \mathrm{H}), 1.35(\mathrm{dd}, J=11.6,5.1 \mathrm{~Hz}, 1 \mathrm{H})$ (signal due to hydroxyl proton not observed); ${ }^{13} \mathrm{C}$ NMR (150 MHz, $\left.\mathrm{CDCl}_{3}\right) \delta 163.2(\mathrm{~m}), 159.01$ (dd, $J=257,2 \mathrm{~Hz}), 158.5(\mathrm{dd}, J=245,2 \mathrm{~Hz}), 155.4,121.15(\mathrm{dd}, J=24,9 \mathrm{~Hz}), 120.5$ (m), $118.5(\mathrm{dd}, J=25,8 \mathrm{~Hz}), 118.3(\mathrm{~d}, J=26 \mathrm{~Hz}), 107.7,83.7,75.7,58.4,56.7,45.8$, 35.5, 32.6, 32.3, 29.1, 28.9; HRESIMS $m / z$ Calcd for $\mathrm{C}_{19} \mathrm{H}_{20} \mathrm{~F}_{2} \mathrm{O}_{3} \mathrm{Na}[\mathrm{M}+\mathrm{Na}]^{+}$: 357.1273, Found: 357.1278.

Compound 29a. Colourless oil (38\% yield); ${ }^{1} \mathrm{H}$ NMR (600 MHz, $\left.\mathrm{CDCl}_{3}\right) \delta 8.12$ (s, 1H), $7.93(\mathrm{~d}, J=8.4 \mathrm{~Hz}, 1 \mathrm{H}), 7.52(\mathrm{~d}, J=8.1 \mathrm{~Hz}, 1 \mathrm{H}), 5.18(\mathrm{dd}, J=11.5,5.5 \mathrm{~Hz}, 1 \mathrm{H})$, $5.09(\mathrm{~s}, 1 \mathrm{H}), 4.99(\mathrm{~s}, 1 \mathrm{H}), 3.74(\mathrm{dd}, J=10.0,5.9 \mathrm{~Hz}, 1 \mathrm{H}), 2.92(\mathrm{br} \mathrm{s}, 1 \mathrm{H}), 2.70(\mathrm{~d}, J=$ $3.1 \mathrm{~Hz}, 1 \mathrm{H}), 2.34(\mathrm{td}, J=14.0,7.5 \mathrm{~Hz}, 1 \mathrm{H}), 2.19(\mathrm{dt}, J=12.9,8.3 \mathrm{~Hz}, 1 \mathrm{H}), 2.00(\mathrm{~m}$, 1H), $1.94-1.88(\mathrm{~m}, 1 \mathrm{H}), 1.70(\mathrm{ddd}, J=11.9,4.9,2.1 \mathrm{~Hz}, 1 \mathrm{H}), 1.61-1.56(\mathrm{~m}, 2 \mathrm{H}), 1.46$ (ddd, $J=12.9,7.3,5.6 \mathrm{~Hz}, 1 \mathrm{H}), 1.33-1.26(\mathrm{~m}, 1 \mathrm{H}), 1.22$ (d, $J=12.4 \mathrm{~Hz}, 1 \mathrm{H})$ (signal due to hydroxyl proton not observed); ${ }^{13} \mathrm{C} \mathrm{NMR}\left(150 \mathrm{MHz}, \mathrm{CDCl}_{3}\right) \delta 164.1(\mathrm{~d}, J=2$ Hz), $162.5(\mathrm{~d}, J=251 \mathrm{~Hz}), 156.1,134.2$ (d, $J=8 \mathrm{~Hz}), 133.1$ (d, $J=34 \mathrm{~Hz}), 122.4$, $123.1(\mathrm{q}, J=273 \mathrm{~Hz}), 120.1(\mathrm{~d}, J=23 \mathrm{~Hz}), 117.1(\mathrm{~d}, J=24 \mathrm{~Hz}), 107.1,83.8,72.8$, 56.7, 52.9, 45.0, 42.0, 32.8, 32.2, 30.6, 28.3; HRESIMS $m / z$ Calcd for $\mathrm{C}_{20} \mathrm{H}_{20} \mathrm{~F}_{4} \mathrm{O}_{3} \mathrm{Na}$ $[\mathrm{M}+\mathrm{Na}]^{+}:$407.1241, Found: 407.1248.

Compound 29ß. Colourless oil (51\% yield); ${ }^{1} \mathrm{H}$ NMR (500 MHz, $\left.\mathrm{CDCl}_{3}\right) \delta 8.10$ (s, 1H), $7.92(\mathrm{dd}, J=6.6,1.4 \mathrm{~Hz}, 1 \mathrm{H}), 7.57-7.46(\mathrm{~m}, 1 \mathrm{H}), 5.21-5.18(\mathrm{~m}, 1 \mathrm{H}), 5.14(\mathrm{~s}, 1 \mathrm{H})$, 5.06-5.05 (m, 1H), $3.85(\mathrm{~s}, 1 \mathrm{H}), 2.76(\mathrm{~s}, 1 \mathrm{H}), 2.63(\mathrm{~d}, J=2.2 \mathrm{~Hz}, 1 \mathrm{H}), 2.39-2.31(\mathrm{~m}$, 1H), $1.97-1.87(\mathrm{~m}, 2 \mathrm{H}), 1.84-1.70(\mathrm{~m}, 4 \mathrm{H}), 1.62-1.56(\mathrm{~m}, 1 \mathrm{H}), 1.50-1.45(\mathrm{~m}, 1 \mathrm{H})$, 1.37 (dd, $J=11.7,5.1 \mathrm{~Hz}, 1 \mathrm{H})$ (signal due to hydroxyl proton not observed); ${ }^{13} \mathrm{C} \mathrm{NMR}$ $\left(150 \mathrm{MHz}, \mathrm{CDCl}_{3}\right) \delta 163.9(\mathrm{~d}, J=3 \mathrm{~Hz}), 162.5(\mathrm{~d}, J=251 \mathrm{~Hz}), 155.4,134.0(\mathrm{~d}, J=8$ $\mathrm{Hz}$ ), $122.4(\mathrm{~m}), 120.9$ (q, $J=271 \mathrm{~Hz}$, not visible in $\left.{ }^{13} \mathrm{C} \mathrm{NMR}\right), 120.1$ (d, $\left.J=23 \mathrm{~Hz}\right)$, 
$117.2(\mathrm{~d}, J=24 \mathrm{~Hz}), 107.8,84.0,77.4,75.7,58.3,56.7,45.8,35.5,32.6,32.3,29.0$, 28.9; HRESIMS $m / z$ Calcd for $\mathrm{C}_{20} \mathrm{H}_{20} \mathrm{~F}_{4} \mathrm{O}_{3} \mathrm{Na}[\mathrm{M}+\mathrm{Na}]^{+}:$407.1241, Found: 407.1240.

Compound 30a. Mixture of diastereomers, colourless oil (53\% yield); ${ }^{1} \mathrm{H}$ NMR (500 $\left.\mathrm{MHz}, \mathrm{CDCl}_{3}\right) \delta 5.08(\mathrm{~d}, J=9.0 \mathrm{~Hz}, 1 \mathrm{H}), 4.97(\mathrm{~d}, J=1.0 \mathrm{~Hz}, 1 \mathrm{H}), 4.95-4.89(\mathrm{~m}, 1 \mathrm{H})$, $4.03(\mathrm{ddd}, J=15.2,11.4,3.7 \mathrm{~Hz}, 1 \mathrm{H}), 3.88-3.80(\mathrm{~m}, 1 \mathrm{H}), 3.77-3.58(\mathrm{~m}, 2 \mathrm{H}), 3.56-3.42$ (m, 1H), 2.72 (br s, 1H), 2.67 (br s, 1H), 2.64-2.59 (m, 1H), 2.26-2.16 (m, 1H), 2.14$2.06(\mathrm{~m}, 1 \mathrm{H}), 2.07-1.95(\mathrm{~m}, 1 \mathrm{H}), 1.88-1.53(\mathrm{~m}, 8 \mathrm{H}), 1.46-1.35(\mathrm{~m}, 1 \mathrm{H}), 1.32-1.21(\mathrm{~m}$ $1 \mathrm{H}), 1.19(\mathrm{~d}, J=11.8 \mathrm{~Hz}, 1 \mathrm{H})$ (signal due to hydroxyl proton not observed); ${ }^{13} \mathrm{C} \mathrm{NMR}$ (126 MHz, $\left.\mathrm{CDCl}_{3}\right) \delta 173.1,156.3,156.2,106.7$ (2C), 81.1, 82.0, 77.4, 72.8 (2C), 69.3, $69.2,68.4,68.3,56.6,56.5,53.0,52.8,44.9,42.0,41.9,41.8,32.7,32.5,32.1$ (2C), 30.7, 30.5, 28.2 (2C), 26.1, 25.8, 25.0, 24.8; HRESIMS $m / z$ Calcd for $\mathrm{C}_{18} \mathrm{H}_{26} \mathrm{O}_{4} \mathrm{Na}$ $[\mathrm{M}+\mathrm{Na}]^{+}:$329.1723, Found: 329.1728.

Compound 30ß. Mixture of diastereomers, colourless oil (41\% yield); ${ }^{1} \mathrm{H}$ NMR (600 $\left.\mathrm{MHz}, \mathrm{CDCl}_{3}\right) \delta 5.06(\mathrm{~s}, 1 \mathrm{H}), 4.99(\mathrm{~s}, 1 \mathrm{H}), 4.92-4.89(\mathrm{~m}, 1 \mathrm{H}), 4.02-1.26(\mathrm{~m}, 1 \mathrm{H}), 3.85-$ $3.82(\mathrm{~m}, 1 \mathrm{H}), 3.78(\mathrm{~s}, 1 \mathrm{H}), 3.58(\mathrm{t}, J=10.3 \mathrm{~Hz}, 1 \mathrm{H}), 3.45(\mathrm{td}, J=11.0,2.9 \mathrm{~Hz}, 1 \mathrm{H})$, 2.71 (br s, 1H), 2.60-2.56 (m, 1H), $2.43(\mathrm{~d}, J=2.4 \mathrm{~Hz}, 1 \mathrm{H}), 2.21(\mathrm{~m}, 1 \mathrm{H}), 2.07-2.01$ (m, 1H), $1.85(\mathrm{~d}, J=11.7 \mathrm{~Hz}, 1 \mathrm{H}), 1.80-1.54(\mathrm{~m}, 9 \mathrm{H}), 1.45-1.44(\mathrm{~m}, 1 \mathrm{H}), 1.30(\mathrm{dd}, J=$ 11.7, $5.0 \mathrm{~Hz}, 1 \mathrm{H})$ (signal due to hydroxyl proton not observed); ${ }^{13} \mathrm{C} \mathrm{NMR}(126 \mathrm{MHz}$, $\left.\mathrm{CDCl}_{3}\right) \delta 172.9(2 \mathrm{C}), 155.6,155.5,107.4(2 \mathrm{C}), 82.1(2 \mathrm{C}), 75.7(2 \mathrm{C}), 69.1(2 \mathrm{C}), 68.3$ (2C), 58.2, 58.1, $56.4(2 \mathrm{C}), 45.7,41.9,41.8,35.5$ (2C), $32.6(2 \mathrm{C}), 32.1(2 \mathrm{C}), 29.0,28.7$, 26.1, 26.0, 24.9 (2C); HRESIMS $m / z$ Calcd for $\mathrm{C}_{18} \mathrm{H}_{26} \mathrm{O}_{4} \mathrm{Na}[\mathrm{M}+\mathrm{Na}]^{+}$: 329.1723, Found: 329.1728.

Biological Assay. 100nL of compounds solubilized in DMSO at a stock concentration of $5 \mathrm{mM}$ were robotically transferred into two optically clear bottom CellCarrier Ultra 96-well plates (PerkinElmer). hONS cells from the control cell line C1 100080003 and 
PD cell line C1 200080013 were added to each well at a density of 1,350 cells per well in $50 \mu \mathrm{L}$ of growth medium (DMEM/F12, 10\% FBS) leading to a final concentration of $10 \mu \mathrm{M}(0.2 \%$ DMSO) for each compound. $0.2 \%$ DMSO was used as negative control. The cells were incubated for $24 \mathrm{~h}$ at $37^{\circ} \mathrm{C}$ under 5\% $\mathrm{CO}_{2}$. Each compound was screened in triplicates on control and Parkinson's disease patient cell line. A log ratio (compound/DMSO) value 2 means the compound has two times more effect on a certain parameter compared to the DMSO control. This would be considered biologically relevant. The cytotoxicity of a compound was assessed on the total number of cells remaining after 24 hours of treatment with a compound.

Cell Staining. After $24 \mathrm{~h}$ of incubation, the medium was aspirated and one 384-well plate was treated with MitoTracker Orange CMTMRos (Invitrogen) (400 nM) for 30 $\min$ at $37^{\circ} \mathrm{C}, 5 \% \mathrm{CO}_{2}$. The second 384-well plate was treated with LysoTracker Red DND-99 (Invitrogen) $(100 \mathrm{nM})$ for $1 \mathrm{~h}$ at $37^{\circ} \mathrm{C} 5 \% \mathrm{CO}_{2}$. Cells were fixed in $4 \%$ paraformaldehyde for $5 \mathrm{~min}$ at room temperature (RT). Cells were washed twice with phosphate-buffered saline (PBS, Sigma-Aldrich) and blocked with 3\% goat serum (Sigma-Aldrich) and 0.2\% Triton X-100 (Sigma-Aldrich) in PBS for $45 \mathrm{~min}$ at RT. Plates were incubated with primary antibodies. Mouse anti- $\alpha$-tubulin 1/4000 (SigmaAldrich) and rabbit anti-LC3b 1/335 (Sigma-Aldrich) were added to the plate treated with MitoTracker and mouse anti-EEA1 1/200 (Sigma-Aldrich) was added to the plate previously treated with LysoTracker. Plates were incubated at RT for $1 \mathrm{~h}$ then washed thrice with PBS. Secondary antibodies goat anti-mouse Alexa-647 1/500 (Invitrogen) and goat anti-rabbit Alexa-488 1/500 (Invitrogen) were added to the first plate and goat anti-mouse Alexa-488 1/500 (Invitrogen) was added to the second plate for $30 \mathrm{~min}$ at RT. Cells were washed twice with PBS and stained with 4',6'-diamidino-2-phenylindole 1/5000 (Dapi, Invitrogen) and with CellMask Deep Red 1/5000 (Invitrogen) for the 
plate treated with LysoTracker and incubated for $10 \mathrm{~min}$ at RT. Cells were washed twice with PBS and plates were stored in the dark at $4{ }^{\circ} \mathrm{C}$ with $50 \mu \mathrm{L}$ of PBS/well.

Imaging and Image Analysis. Plates were imaged automatically using Operetta (PerkinElmer), a high content imaging system using a 20X high numerical aperture objective lens. Five images per well for each wavelength were collected. Individual cell segmentation was done using the Harmony software and measurements for each cell were performed generating 38 parameters from 6 dyes: DAPI, $\alpha$-tubulin staining, MitoTracker Orange CMTMRos, LC3b staining, LysoTracker Red DND-99 and EEA1 staining for individual cell lines. The normality of the data was checked for each parameter and a $\log _{2}$ Compound/DMSO ratio was calculated for each compound.

Stability test of compounds. Stability test of compounds 14,150 and $28 \beta$ was conducted on the following six different conditions of culture medium (DMEM/F12 $+10 \%$ FBS): Compound mixed with, 1. $500 \mu \mathrm{L}$ of medium; 2. $500 \mu \mathrm{L}$ of medium incubated at $37{ }^{\circ} \mathrm{C}, 5 \% \mathrm{CO}_{2}$ for 24 hours; 3. $500 \mu \mathrm{L}$ of medium incubated at $37{ }^{\circ} \mathrm{C}, 5 \%$ $\mathrm{CO}_{2}$ for 48 hours; 4. $500 \mu \mathrm{L}$ of medium containing Parkinson's disease cell; 5. $500 \mu \mathrm{L}$ of medium containing Parkinson's disease cell incubated at $37{ }^{\circ} \mathrm{C}, 5 \% \mathrm{CO}_{2}$ for 24 hours; 6. $500 \mu \mathrm{L}$ of medium containing Parkinson's disease cell incubated at $37{ }^{\circ} \mathrm{C}, 5 \% \mathrm{CO}_{2}$ for 48 hours. Controls experiments were consist of $500 \mu \mathrm{L}$ of medium and $500 \mu \mathrm{L}$ of medium containing Parkinson's disease cell line. Both were extracted after 0 and 48 hours. All the samples were extracted and analysed under the same condition as the standard samples.

As for the standard, compounds $14(0.2 \mathrm{mg}), \mathbf{1 5 0}(0.3 \mathrm{mg})$ and $\mathbf{2 8} \boldsymbol{\beta}(0.3 \mathrm{mg})$ were dissolved in $500 \mu \mathrm{L}$ water and then extracted by $500 \mu \mathrm{L}$ dichloromethane three times. The DCM extracts of each compound were dried, dissolved in $200 \mu \mathrm{L}$ methanol, of which $5 \mu \mathrm{L}$ was injected to LC-MS. Solvents $\mathrm{H}_{2} \mathrm{O}(0.1 \%$ FA) and $\mathrm{MeOH}(0.1 \%$ FA) 
was used for the LC-MS analysis with the following method: isocratic elution of $10 \%$ $\mathrm{MeOH}$ for $1 \mathrm{~min}$ followed by a linear gradient to $100 \% \mathrm{MeOH}$ in $9 \mathrm{~min}$, held isocratic for $1.50 \mathrm{~min}$, then a linear gradient to the initial condition of $10 \% \mathrm{MeOH}$ in $0.5 \mathrm{~min}$. The total run time for each extract injection was $12 \mathrm{~min}$ and flow rate was $0.3 \mathrm{ml} / \mathrm{min}$.

\section{AUTHOR INFORMATION}

\section{Corresponding Author}

*E-mail: r.quinn@griffith.edu.au. Phone:+61 737356006

\section{ORCID}

Ronald J Quinn: 0000-0002-4022-2623

\section{Notes}

The authors declare no conflict of interest

\section{ACKNOWLEDGENMENTS}

This research was funded by the Australian Government through the Australian Research Council (ARC) Discovery Projects Grant DP130102400 and the Linkage Infrastructure, Equipment and Facilities scheme LE140100119 and LE20100170.

\section{ASSOCIATED CONTENT}

\section{Supporting Information}

The Supporting information is available free of charge on the ACS Publications website at DOI: 
Details of Force Fields, analysis of 45 combinations of di-substituted libraries, 161 natural products containing the cedrane scaffold, substituent analysis of the 161 natural products, molecular formula strings and physicochemical properties of synthesised compounds, compound 19 coupling constant modelling, cellular parameters used in phenotypic assay, heat maps, NMR spectra

\section{References}

1. Harvey, A. L.; Edrada-Ebel, R.; Quinn, R. J. The re-emergence of natural products for drug discovery in the genomics era. Nat Rev Drug Discov 2015, 14, 111.

2. Newman, D. J.; Cragg, G. M. Natural products as sources of new drugs from 1981 to 2014. J. Nat. Prod. 2016, 79, 629-661.

3. Grabowski, K.; Schneider, G. Properties and architecture of drugs and natural products revisited. Curr. Chem. Biol. 2007, 1, 115-127.

4. Rosén, J.; Gottfries, J.; Muresan, S.; Backlund, A.; Oprea, T. I. Novel chemical space exploration via natural products. J. Med. Chem. 2009, 52, 1953-1962.

5. Ertl, P.; Roggo, S.; Schuffenhauer, A. Natural product-likeness score and Its application for prioritization of compound libraries. J. Chem. Inf. Model. 2008, 48, 6874.

6. Newman, D. J. Natural products as leads to potential drugs: an old process or the new hope for drug discovery? J. Med. Chem. 2008, 51, 2589-2599.

7. Kumar, K.; Waldmann, H. Synthesis of natural product inspired compound collections. Angew. Chem. Int. Ed. Engl. 2009, 48, 3224-3242.

8. Lovering, F.; Bikker, J.; Humblet, C. Escape from flatland: increasing saturation as an approach to improving clinical success. J. Med. Chem. 2009, 52, 6752-6756.

9. Lovering, F. Escape from Flatland 2: complexity and promiscuity. Med. Chem. Commun. 2013, 4, 515-519. 
10. Kellenberger, E.; Hofmann, A.; Quinn, R. J. Similar interactions of natural products with biosynthetic enzymes and therapeutic targets could explain why nature produces such a large proportion of existing drugs. Nat. Prod. Rep. 2011, 28, 1483-1492. 11. McArdle, B. M.; Campitelli, M. R.; Quinn, R. J. A common protein fold topology shared by flavonoid biosynthetic enzymes and therapeutic targets. J. Nat. Prod. 2006, 69, $14-17$.

12. Sturm, N.; Quinn, R. J.; Kellenberger, E. Similarity between flavonoid biosynthetic enzymes and flavonoid protein targets captured by three-dimensional computing approach. Planta Med. 2015, 81, 467-473.

13. Sturm, N.; Rognan, D.; Quinn, R. J.; Kellenberger, E. Comparing atom-based with residue-based descriptors in predicting binding site similarity: do backbone atoms matter? Future Med Chem 2016, 8, 1871-1885.

14. Sturm, N.; Quinn, R. J.; Kellenberger, E. Structural searching of biosynthetic enzymes to predict protein targets of natural products. Planta Med. 2017.

15. Barker, A.; Kettle, J. G.; Nowak, T.; Pease, J. E. Expanding medicinal chemistry space. Drug Discov. Today 2013, 18, 298-304.

16. Schreiber, S. L. Target-oriented and diversity-oriented organic synthesis in drug discovery. Science 2000, 287, 1964-1969.

17. Tan, D. S. Diversity-oriented synthesis: exploring the intersections between chemistry and biology. Nat. Chem. Biol. 2005, 1, 74-84.

18. Burke, M. D.; Lalic, G. Teaching target-oriented and diversity-oriented organic synthesis at harvard university. Chem. Biol. 2002, 9, 535-541.

19. Wender, P. A.; Verma, V. A.; Paxton, T. J.; Pillow, T. H. Function-oriented synthesis, step economy, and drug design. Acc. Chem. Res. 2008, 41, 40-49.

20. Nören-Müller, A.; Reis-Corrêa, I.; Prinz, H.; Rosenbaum, C.; Saxena, K.; Schwalbe, H. J.; Vestweber, D.; Cagna, G.; Schunk, S.; Schwarz, O.; Schiewe, H.; Waldmann, H. Discovery of protein phosphatase inhibitor classes by biology-oriented synthesis. Proc. Natl Acad. Sci. USA 2006, 103, 10606-10611. 
21. Wetzel, S.; Bon, R. S.; Kumar, K.; Waldmann, H. Biology-oriented synthesis. Angew. Chem. Int. Ed. Engl. 2011, 50, 10800-10826.

22. Tajabadi, F.; Campitelli, M.; Quinn, R. Scaffold flatness: reversing the trend. Springer Sci. Rev. 2013, 1, 141-151.

23. Hert, J.; Irwin, J. J.; Laggner, C.; Keiser, M. J.; Shoichet, B. K. Quantifying biogenic bias in screening libraries. Nat. Chem. Biol. 2009, 5, 479-483.

24. Rodríguez, A. D.; Ramírez, C.; Rodríguez, I. I.; Barnes, C. L. Novel terpenoids from the west indian sea whip Pseudopterogorgia elisabethae (Bayer). Elisapterosins A and B: rearranged diterpenes possessing an unprecedented cagelike framework. J. Org. Chem. 2000, 65, 1390-1398.

25. Tanaka, N.; Kashiwada, Y.; Sekiya, M.; Ikeshiro, Y.; Takaishi, Y. Takaneones A-C, prenylated butylphloroglucinol derivatives from Hypericum sikokumontanum. Tetrahedron Lett. 2008, 49, 2799-2803.

26. Kobayashi, J. i.; Inubushi, A.; Hosoyama, H.; Yoshida, N.; Sasaki, T.; Shigemori, H. Taxuspines E-H and J, new taxoids from the Japanese yew Taxus cuspidata. Tetrahedron 1995, 51, 5971-5978.

27. Wang, L.; Bai, L.; Tokunaga, D.; Watanabe, Y.; Hasegawa, T.; Sakai, J.-i.; Tang, W.; Bai, Y.; Hirose, K.; Yamori, T.; Tomida, A.; Tsuruo, T.; Ando, M. The polar neutral and basic taxoids isolated from needles and twigs of Taxus cuspidata and their biological activity. J. Wood Sci. 2008, 54, 390-401.

28. Winkelmann, K.; Heilmann, J.; Zerbe, O.; Rali, T.; Sticher, O. New phloroglucinol derivatives from Hypericum papuanum. J. Nat. Prod. 2000, 63, 104-108. 29. Sako, M.; Suzuki, H.; Hirota, K. Syntheses of taxuspine C derivatives as functional inhibitors of P-glycoprotein, an ATP-associated cell-membrane transporter. Chem. Pharm. Bull. 1998, 46, 1135-1139.

30. Bernhardt, G.; Biersack, B.; Bollwein, S.; Schobert, R.; Zoldakova, M. Terpene conjugates of diaminedichloridoplatinum(II) complexes: antiproliferative effects in HL- 
60 leukemia, 518A2 melanoma, and HT-29 colon cancer cells. Chem. Biodivers. 2008, 5, $1645-1659$.

31. Biersack, B.; Dietrich, A.; Zoldakova, M.; Kalinowski, B.; Paschke, R.; Schobert, R.; Mueller, T. Lipophilic Pt(II) complexes with selective efficacy against cisplatinresistant testicular cancer cells. J. Inorg. Biochem. 2011, 105, 1630-1637.

32. Vial, M.-L.; Zencak, D.; Grkovic, T.; Gorse, A.-D.; Mackay-Sim, A.; Mellick, G. D.; Wood, S. A.; Quinn, R. J. A grand challenge. 2. Phenotypic profiling of a natural product library on Parkinson's patient-derived cells. J. Nat. Prod. 2016, 79, 1982-1989.

33. Matigian, N.; Abrahamsen, G.; Sutharsan, R.; Cook, A. L.; Vitale, A. M.; Nouwens, A.; Bellette, B.; An, J.; Anderson, M.; Beckhouse, A. G.; Bennebroek, M.; Cecil, R.; Chalk, A. M.; Cochrane, J.; Fan, Y.; Féron, F.; McCurdy, R.; McGrath, J. J.; Murrell, W.; Perry, C.; Raju, J.; Ravishankar, S.; Silburn, P. A.; Sutherland, G. T.; Mahler, S.; Mellick, G. D.; Wood, S. A.; Sue, C. M.; Wells, C. A.; Mackay-Sim, A. Disease-specific, neurosphere-derived cells as models for brain disorders. Dis. Model. Mech. 2010, 3, 785 .

34. Cook, A. L.; Vitale, A. M.; Ravishankar, S.; Matigian, N.; Sutherland, G. T.; Shan, J.; Sutharsan, R.; Perry, C.; Silburn, P. A.; Mellick, G. D.; Whitelaw, M. L.; Wells, C. A.; Mackay-Sim, A.; Wood, S. A. NRF2 activation restores disease related metabolic deficiencies in olfactory neurosphere-derived cells from patients with sporadic Parkinson's disease. PLoS One 2011, 6, e21907.

35. Zheng, W.; Thorne, N.; McKew, J. C. Phenotypic screens as a renewed approach for drug discovery. Drug Discov. Today 2013, 18, 1067-1073.

36. Bemis, G. W.; Murcko, M. A. The properties of known drugs. 1. Molecular frameworks. J. Med. Chem. 1996, 39, 2887-2893.

37. Sakoulas, G.; Nam, S.-J.; Loesgen, S.; Fenical, W.; Jensen, P. R.; Nizet, V.; Hensler, M. Novel bacterial metabolite merochlorin A demonstrates in vitro activity against multi-drug resistant methicillin-resistant Staphylococcus aureus. PLoS One 2012, 7, e29439. 
38. Bugarin, A.; Connell, B. T. Chiral nickel(II) and palladium(II) NCN-pincer complexes based on substituted benzene: synthesis, structure, and Lewis acidity. Organometallics 2008, 27, 4357-4369.

39. Monti, S. A.; Chen, S.-C.; Yang, Y.-L.; Yuan, S.-S.; Bourgeois, O. P. Rearrangement approaches to polycyclic skeletons. 1. Bridgehead-substituted bicyclo[3.2.1] octene derivatives from bicyclo[2.2.2] octene precursors. J. Org. Chem. 1978, 43, 4062-4069.

40. Kim, D.; Shim, P. J.; Lee, J.; Park, C. W.; Hong, S. W.; Kim, S. Construction of the tricyclo[5.3.1.01,5] undecane system by a novel tandem Pinacol rearrangement-ene strategy: a formal total synthesis of $( \pm)$-perhydrohistrionicotoxin. J. Org. Chem. 2000, $65,4864-4870$.

41. Baell, J. B.; Holloway, G. A. New substructure filters for removal of pan assay interference compounds (PAINS) from screening libraries and for their exclusion in bioassays. J. Med. Chem. 2010, 53, 2719-2740.

42. Cardillo, G.; De Simone, A.; Mingardi, A.; Tomasini, C. Synthesis of $\beta, \gamma-$ unsaturated esters from $\alpha, \beta$-unsaturated acid chlorides. Synlett 1995, 1995, 1131-1132.

43. Abraham, W.-R.; Washausen, P.; Kieslich, K. Microbial hydroxylation of cedrol and cedrene. Z. Naturforsch. 1987, 42c, 414-419.

44. Maatooq, G.; El-Sharkawy, S.; Afifi, M. S.; Rosazza, J. P. N. Microbial transformation of cedrol. J. Nat. Prod. 1993, 56, 1039-1050.

45. Armarego, W. L. F.; Chai, C. Purification of laboratory chemicals, 6th edition. 2009. 
For Table of Contents Use Only

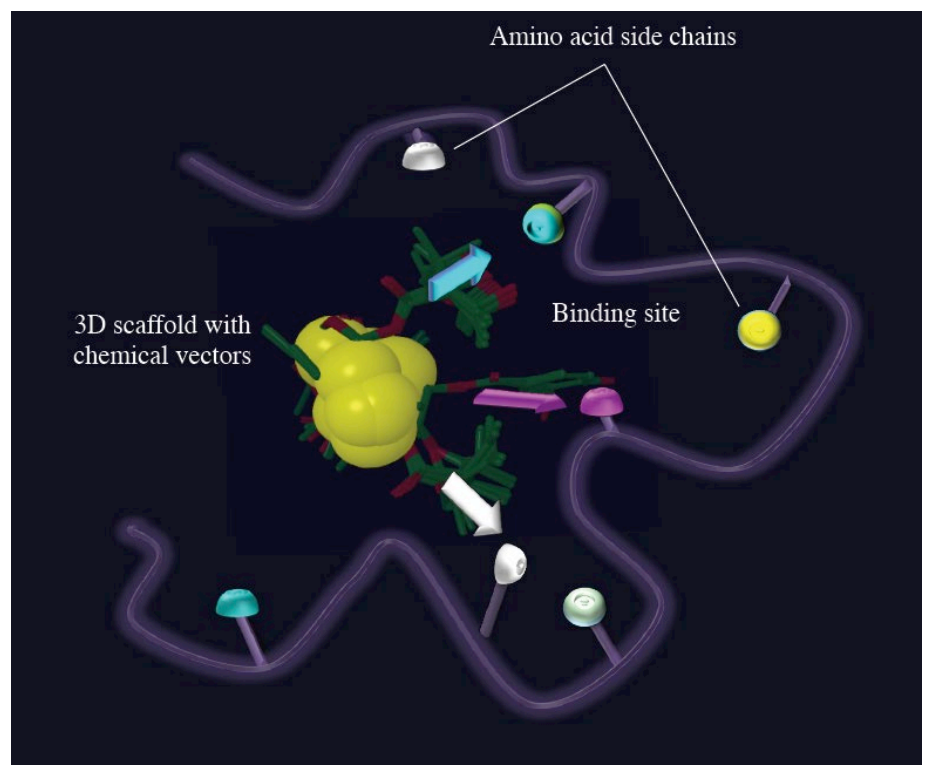

